\title{
Between standardisation and discretion The priority setting of triage nurses
}

\author{
Lars E.F. Johannessen
}

Dissertation submitted for the degree of Philosophiae Doctor (PhD)

Centre for the Study of Professions OsloMet - Oslo Metropolitan University

Spring 2018 
CC-BY-SA OsloMet - storbyuniversitetet

OsloMet Avhandling 2018 nr 20

ISSN 2535-471X

ISBN 978-82-8364-104-2

OsloMet - storbyuniversitetet

Universitetsbiblioteket OsloMet

Skriftserien

St. Olavs plass 4,

0130 Oslo,

Telefon (47) 64849000

Postadresse:

Postboks 4, St. Olavs plass

0130 Oslo

Trykket hos Byråservice

Trykket på Scandia 2000 white, 80 gram på materiesider/200 gram på coveret 
Standards are not one uniform thing, with one uniform effect.

Timmermans and Berg, The Gold Standard 



\section{Acknowledgements}

While at times solitary, academic work is also fundamentally social, and it is humbling to reflect on the number of people who have supported this dissertation. First of all, I would like to thank my supervisors, Dag Album and Marte Mangset, for their invaluable contributions. Dag, you have been a vital support throughout. You approach the social world with a refreshing mixture of curiosity, excitement and disinterestedness, and it has been inspiring to witness your sociological imagination at work. Marte, you came in towards the end and provided the necessary insight and inspiration to push me over the finish line. I am particularly grateful for the way you challenged me to articulate my theoretical and methodological stance, and for your encouraging spirit and constant availability.

I would also like to thank two of my most significant others - my soon-to-be wife, Beatrice Johannessen and my work wife, Erik Børve Rasmussen. Beatrice, you have read and critiqued, listened and encouraged, hugged and smiled. It is impossible to overstate your importance - not only for this project, but for my life more generally. For this, I love you. Erik, we have been each other's informal supervisors for a long time, and you have provided a constant stream of feedback - most times inspiring, sometimes ridiculously nit-picky, but always constructive and well meant. I sort of love you too, but, you know, in a totally manly way.

I am also grateful to the Centre for the Study of Professions - and its leader, Oddgeir Osland for believing in my prospects and project. With its interdisciplinary workforce and virtually non-existent boundaries between $\mathrm{PhD}$ students and tenured staff, the Centre has proved a stimulating workplace. And while Norway is not particularly known for its workshop culture, the Centre's 'GPPS' is an important exception; I have profited immensely from the feedback of its various sociologists, anthropologists, historians and philosophers. I am also grateful to the Centre's 'qualitative analysis gang', and especially to its original cast of Runa, Torbjørn, Peter, Erik and Tanja, who all helped me make sense of my data. And finally, I would like to thank the attendants in the closing seminar on my work, especially Kristin Buvik, who gave a thorough and inspiring critique of my dissertation, and who, most importantly, managed to convey her comments in a motivating manner (also, thanks to Tanja Nordberg for taking notes!).

Beyond the Centre, I would like to thank the people at Yale University's Center for Cultural Sociology, where I spent the spring semester of 2017. I benefitted greatly from presenting two 
of my papers at its workshop and Spring Conference, respectively, and I am especially grateful to Phil Smith and Jeff Alexander for taking me in and giving feedback on my work. Some individuals deserve special praise. Mats Lillehagen has given valuable comments throughout; Tore Rafoss has been, well, Tore; Berit Bringedal has offered important insights on healthcare and priority setting (especially during our time as neighbours in Harlem); and Ole Berg gave important feedback on the project in the early stages, sensitising me to the peculiarities of the Norwegian healthcare system. My mother and father, Anne and Kjell Johannessen, have provided emotional (and material) support, and, more importantly, taught me the value of hard and honest work. My big brother, Marius Rohde Johannessen, paved the way for us Johannessens into the academic system, also offering feedback and inspiration from day one. Thank you.

Last but not least, I would like to thank the workers in the emergency primary care clinics I studied. You all welcomed me with such warmth and generosity that I, at times, wondered whether nursing would have been a more rewarding vocation. I am particularly thankful to the workers I shadowed, as well as my main contact in nursing management and the physician who facilitated access to the main clinic. The project would not have been possible without you, and for that, I am grateful. 


\section{Summary}

This dissertation explores the relationship between standardisation and discretion in professional work at street level, using the priority setting of triage nurses as its case. Triage nurses are employed at the frontline of emergency medical services, where they work to assess the urgency of patients' complaints. This work can be very challenging, requiring rapid assessments of a large group of unknown and unsorted patients, some of whom may be critically ill.

To aid these assessments, emergency services have increasingly introduced standardised triage systems that specify how nurses should proceed in interpreting and prioritising cases. Triage systems reflects a broader trend in healthcare, which has seen a widespread introduction of clinical practice guidelines, all seeking to generate uniformity and quality control by streamlining clinical decision making. The introduction of these guidelines has been described as an unprecedented form of standardisation of professional clinical work, but there is little consensus regarding their effects. While proponents argue that clinical practice guidelines are an important means of improving quality and efficiency, critics denounce them for promoting bureaucratisation, homogenisation and so-called 'cookbook medicine'. Observing this impasse, there have been calls for an empirically grounded 'sociology of standardisation' to acknowledge that guidelines can have different effects in different settings and to explore standardisation on a case-by-case basis.

Informed by that proposal, this dissertation explores the relationship between standardisation and discretion in triage nurses’ priority setting. The dissertation is based on nine months of fieldwork in a Norwegian emergency primary care clinic (EPCC), where nurses were required to assess patients using the Manchester Triage System (MTS). Observations revealed that nurses regularly departed from the MTS while also seeming to be influenced by the system in a number of ways. On this basis, the dissertation addresses the question of how and why nurses departed from the MTS and, conversely, how the MTS influenced their assessments.

The introduction and the four associated articles show how nurses supplemented the MTS with additional skills and knowledge, and how this led them to adjust or override the priorities formally prescribed by the system. While they had several reasons for so doing, their primary concern was to 'correct' the MTS and to ensure more precise prioritisation of patients. However, the MTS also played a significant role in their assessments by restricting, enabling and supporting priority setting. 
Beyond shedding light on discretionary practices among triage nurses, the dissertation makes three more general contributions to the sociology of standardisation. First, it helps to bridge the gaps between the sociology of standardisation and the literatures on street-level bureaucracy and categorisation. In so doing, it identifies fruitful theoretical linkages for future studies of standardisation and discretion in street-level categorisation of clients.

Secondly, the in-depth exploration of nurses' use of the MTS provides a rich account of the difficulties of streamlining clinical practice. Despite its elaborate design, the MTS was too 'thin' to match the complexity of triage nurses' work, and to follow it unreflectively would be to the detriment of both patients and staff. For that reason, nurses found it necessary to render the guidelines ‘thicker' by making situated judgments, illustrating the crucial role of additional skills and knowledge in making standards work.

Finally, the dissertation shows how the MTS (despite its shortcomings) affected nurses' work in multiple ways, illustrating how guidelines interact with professional practice. In so doing, the dissertation transcends the either/or language that characterises much of the debate around standardisation, instead providing a nuanced account of the interplay between prescribed and discretionary aspects of triage nursing. 


\section{Sammendrag}

Avhandlingen utforsker forholdet mellom standardisering og skjønn i profesjonelt arbeid ved å bruke en etnografisk studie av triagesykepleiere på legevakt som sitt case. Triage er fransk for å sortere, og triagesykepleiere har ansvar for å sortere innkomne pasienter etter ulike grader av hast - og slik bestemme deres plass i køen til en av legevaktens leger. Triage kan være krevende arbeid. Sykepleierne må gjøre raske vurderinger av mange ukjente og usorterte pasienter, og det kan få store konsekvenser om de overser kritisk sykdom.

For å lette slikt sorteringsarbeid har flere og flere akuttinstitusjoner innført standardiserte triagesystemer, som spesifiserer hvordan man skal gå fram for å fortolke og prioritere pasienter. Dette reflekterer en allmenn tendens i helsevesenet, der man de siste tiårene har sett en svært sterk vekst i bruk av retningslinjer for å standardisere klinisk beslutningstaking. Bruken av retningslinjer er omstridt. Forkjempere mener de sikrer effektive og evidensbaserte helsetjenester, mens kritikere hevder de fører til byråkratisering, homogenisering og såkalt «kokebok-medisin». Frontene kan være steile, og en respons har vært framveksten av en såkalt «standardiseringssosiologi» som forfekter en alternativ, empiridrevet tilnærming til spørsmål om standardisering. Utgangspunktet er at retningslinjer kan ha ulike effekter i ulike settinger, og oppfordringen er å gå åpent og empirisk til verks for å utforske hvordan de faktisk virker på helsevesenets bakkeplan.

Med inspirasjon fra standardiseringssosiologien utforsker denne avhandlingen forholdet mellom standardisering og skjønn i triagesykepleieres arbeid. Avhandlingen er basert på ni måneder med feltarbeid i en norsk storbylegevakt, der triagesykepleiere var pålagt å bruke Manchester Triage System (MTS) i prioriteringen av pasienter. Observasjoner viste at sykepleierne regelmessig avvek fra MTS, men også at systemet hadde en rekke konsekvenser for deres prioritering. Med dette som utgangspunkt søker avhandlingen svar på hvordan og hvorfor sykepleierne avvek fra MTS, og hvordan MTS påvirket pasientprioriteringen deres.

Gjennom fire artikler og en kappe viser avhandlingen hvordan sykepleierne supplerte MTS med egne kunnskaper og ferdigheter, og hvordan dette ofte ledet dem til å overstyre systemets formelt foreskrevne prioriteringer. Sykepleierne gjorde dette første og fremst for å «korrigere» MTS og prioritere pasienter på mer presist vis. Samtidig spilte også MTS en sentral rolle i arbeidet deres, ved å begrense, muliggjøre og støtte dem i deres prioriteringer. 
Ved å kartlegge sykepleiernes skjønnsmessige prioritering gir avhandlingen tre mer generelle bidrag til standardiseringssosiologien. For det første bidrar den til å bygge bro mellom standardiseringssosiologi og teorier om bakkebyråkrater og kategorisering. Med det legger den et teoretisk fundament for videre studier av standardisering og skjønn i klientkategorisering på bakkenivå.

For det andre gir avhandlingen en rik illustrasjon av utfordringene med å strømlinjeforme klinisk praksis. Til tross for utførlige retningslinjer kunne ikke MTS matche kompleksiteten i triagesykepleiernes oppgaver, og hadde man fulgt systemet slavisk, ville det vært til skade for både pasienter og ansatte. Sykepleierne måtte derfor supplere MTS med egne kunnskaper og ferdigheter, en praksis som illustrerer hvordan retningslinjer må gjøres «tykkere» for at de skal fungere overhodet.

For det tredje viser avhandlingen hvordan MTS, på tross av systemets begrensninger, likevel preget sykepleiernes arbeid på en rekke måter. Avhandlingen gir en nyansert analyse av samspillet mellom retningslinjer og profesjonell praksis, og demonstrerer slik fruktbarheten av å gå åpent og empirisk til verks for å forstå retningslinjers mange og ulike virkninger. 


\section{Contents}

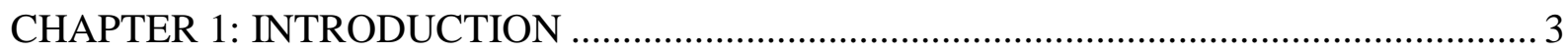

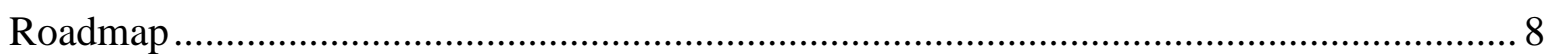

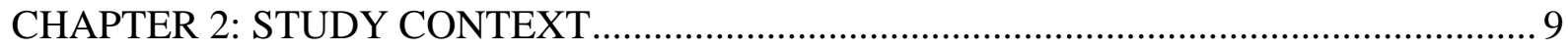

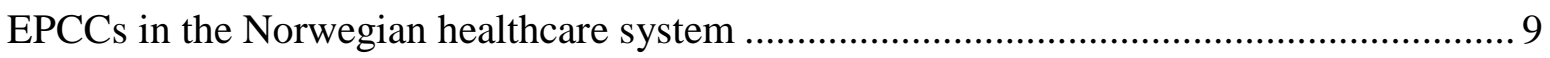

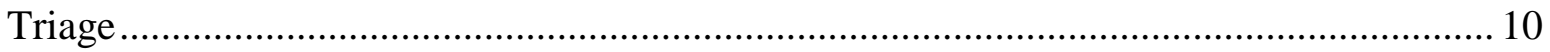

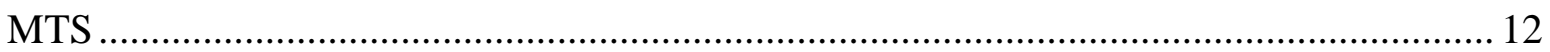

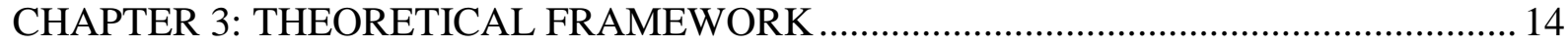

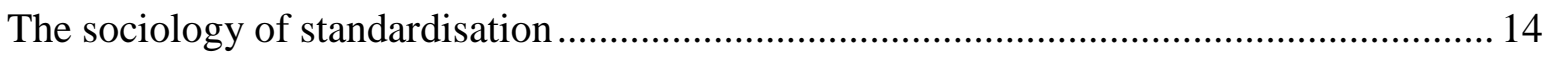

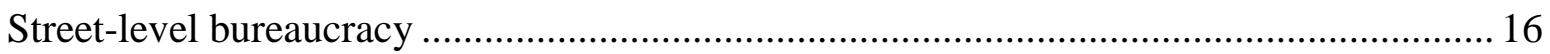

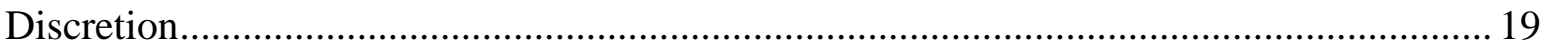

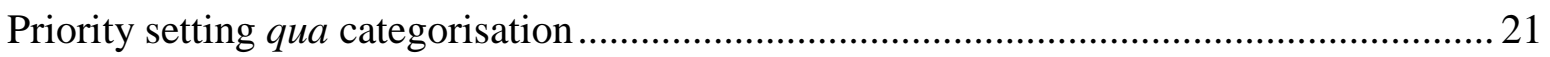

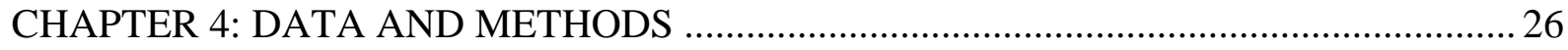

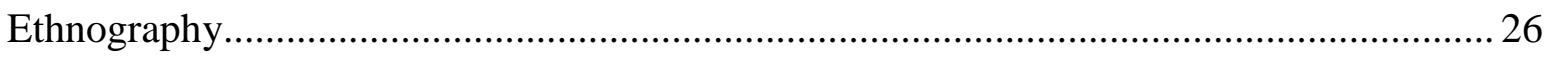

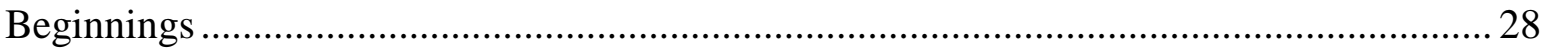

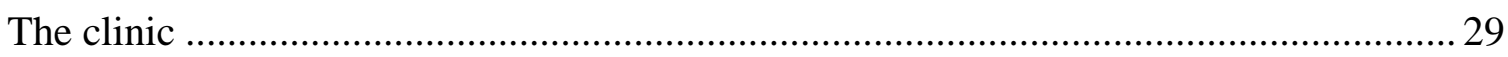

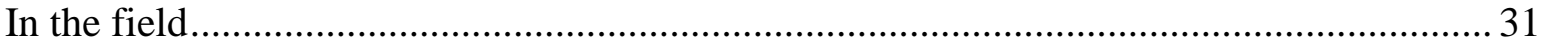

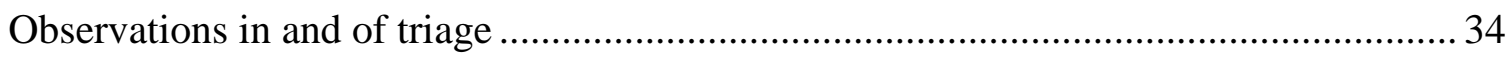

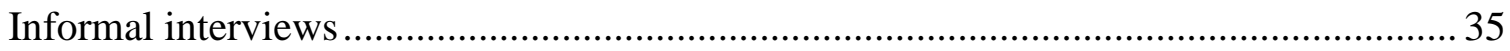

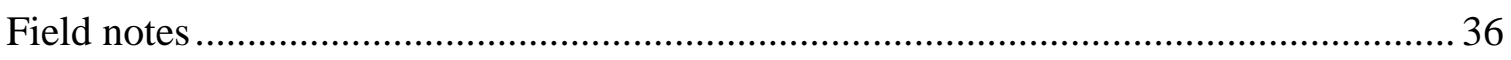

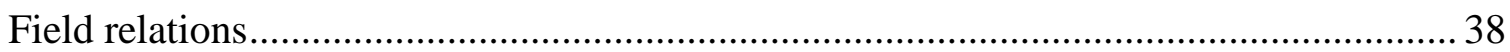

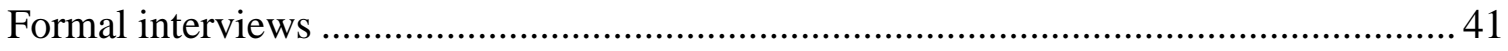

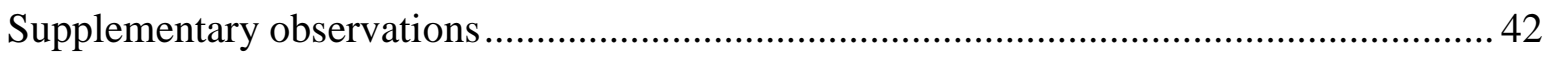

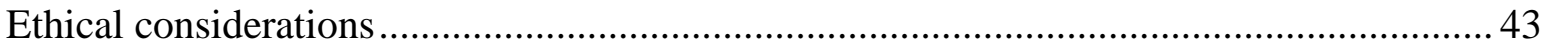

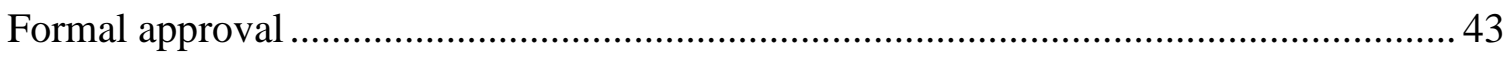

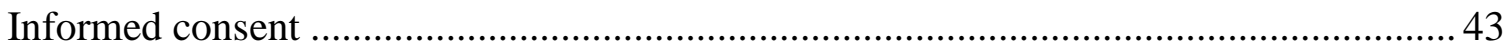

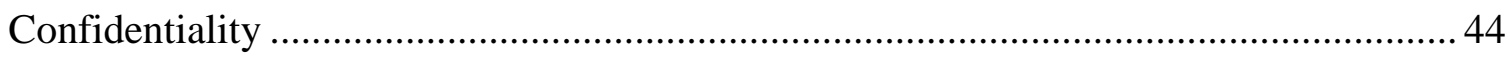

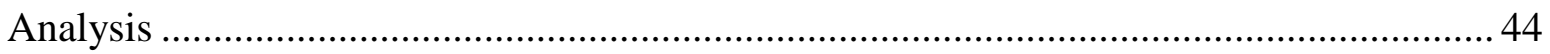

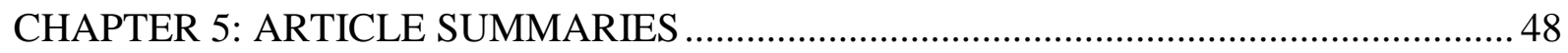

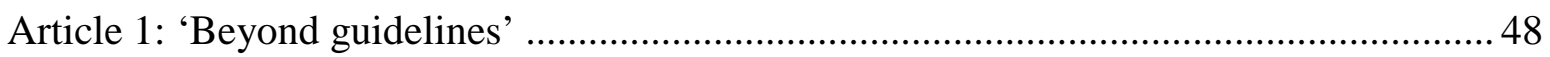

Article 2: 'Workplace assimilation and professional jurisdiction' ..................................... 49

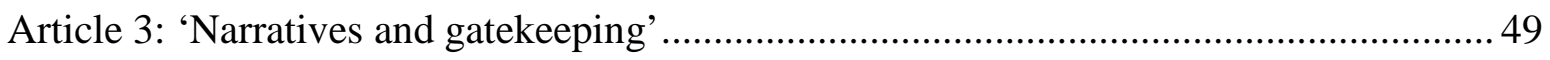

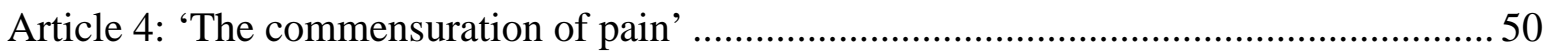

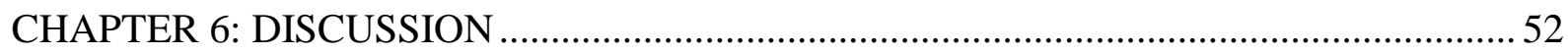

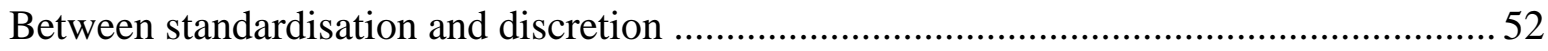

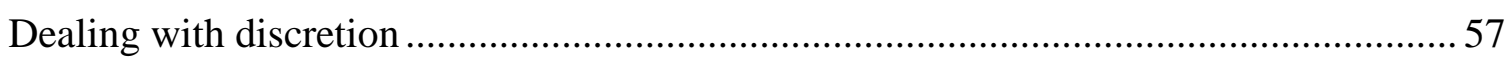

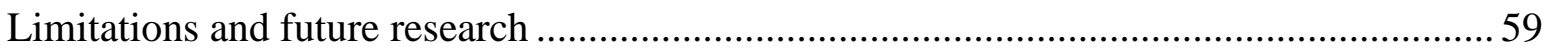

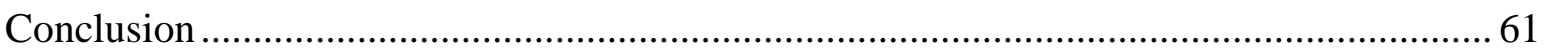

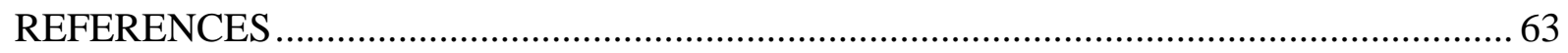

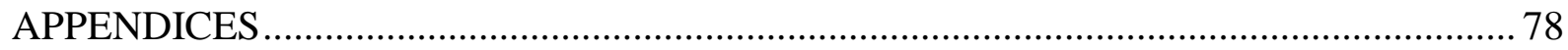




\section{List of articles}

Article 1 Johannessen, L.E.F. (2017). Beyond guidelines: Discretionary practice in face-to-face triage nursing. Sociology of Health \& Illness 39(7): 1180-1194.

Article 2 Johannessen, L.E.F. (2018). Workplace assimilation and professional jurisdiction: How nurses learn to blur the nursing-medical boundary. Social Science \& Medicine 201: 51-58.

Article 3 Johannessen, L.E.F. (2018). Narratives and gatekeeping: Making sense of triage nurses' practice. Published online ahead of print in Sociology of Health \& Illness.

Article 4 Johannessen, L.E.F. (forthcoming). The commensuration of pain: How nurses transform subjective experience into objective numbers. Under review in Social Studies of Science. 


\section{Chapter 1: Introduction}

It is Monday evening and I am sitting next to Nurse Mary in the frontline of the emergency primary care clinic. We are in a 'triage booth'; she is doing 'triage'—that is, assessing the urgency of patients' complaints. The waiting room is noisy and crowded, and we are both starting to get tired. Mary has just spent four minutes assessing a man with ear pains; he was her thirty-fourth patient today. After deciding on a 'green' priority — the second lowest of five — and sending the man to the second waiting area in the clinic, Mary tries to complete her documentation. For the first time in this particular assessment, she opens her 'triage manual'; she is supposed to choose one of its 53 flowcharts to guide her assessment. Browsing through the chart for 'Ear problems', she mutters, half in my direction, "So, where can I fit him?”

This dissertation explores the relationship between standardisation and discretion in professional work at street level, using the priority setting of triage nurses as its case. Standardisation is a key concern in modern societies, driven by multiple actors that include states, companies, NGOs and professional bodies, all seeking to "render the modern world equivalent across cultures, time, and geography” (Timmermans and Epstein 2010: 69). The range of standardisation seems ever-increasing, as evidenced in the spread of safety standards, performance standards, standardised testing, grading standards and labour standards, to name but a few. Indeed, according to Brunsson and Jacobsson, “A proper understanding of standardization is a prerequisite for understanding the way modern society functions” (2000: 15).

Arguably, Brunsson and Jacobsson's claim is especially relevant for contemporary healthcare. Since the late 1980s, the field of healthcare has been involved in a massive standardisation movement called evidence-based medicine, which seeks to generate uniformity and quality control primarily by means of clinical practice guidelines (Knaapen 2014; Mykhalovskiy and Weir 2004; Timmermans and Berg 2003; Weisz et al. 2007). Also referred to as algorithms, protocols and procedural standards, these tools specify how processes should be performed in a step-by-step manner (Berg 1997a). Mass introduction of clinical practice guidelines represents a broader shift in how professional work is regulated; while earlier attempts sought primarily to streamline working conditions, clinical practice guidelines instead seek "to intervene at the moment of a health care provider's special expertise: medical decision making” (Timmermans and Berg 2003: 13). Accordingly, as Timmermans has observed, “Clinical practice guidelines constitute an unprecedented form of standardization of professional clinical care” (2005: 491). 
The introduction of evidence-based guidelines is not confined to the medical profession; indeed, it has been suggested that we are now seeing an 'evidence-based everything' (Fowler 1997). Triage nursing is a central case of this trend. Working at the frontline of emergency medical services (EMS), triage nurses are responsible for assessing the urgency of patients' complaints (FitzGerald et al. 2010). Since the mid-1990s, EMS organisations have turned increasingly to triage systems to aid nurses’ assessments (Iserson and Moskop 2007). Although varying in design, all such systems include guidelines for interpreting and prioritising cases. Triage systems are less optional in character than most medical guidelines, aiming for near-exhaustive codification of the decision-making process. The aim is to ensure more systematic and objective assessment, so increasing quality and efficiency.

These are commendable goals, as triage can be challenging work. For many acutely ill patients, EMS is often their first point of contact with the healthcare system, which means that triage nurses have little or no prior knowledge about the patients they assess. Additionally, patients often present with problems that elude simple textbook description, and nurses must typically make a rapid assessment, as there are many others waiting in line. The fact that many EMS organisations struggle increasingly with overcrowding (cf. Pines et al. 2011) adds to the challenge for triage nurses in terms of both time pressure and the need for fine-grained sorting of patients. A further pressure is that these assessments can have significant consequences for the patients in question. At worst, the patient may die while waiting to see an EMS physician if a critical illness is overlooked. More generally, triage nurses play a significant role in determining how long patients have to experience anxiety, despair or pain while waiting, and in how they are subsequently understood and treated by other actors in the EMS.

However, while there is broad consensus on the need to ensure appropriate priority setting in triage, there are differing views about the utility of guidelines in achieving that goal. Some argue that guidelines are central to reducing arbitrariness and bias in healthcare work (cf. Berkwits 1998; Geyman 1999; Rosoff 2001), but critics of this approach denounce standards for increasing the bureaucratisation and homogenisation of clinical practice (Haug 1988; Ritzer 1993), leading to a form of so-called 'cookbook medicine' (Harrison 1998; Hunter 1996). As many have observed, this debate can be heated, with a tendency to absolutism on both sides (cf. Knaapen 2014; Timmermans and Berg 2003).

To escape this impasse, there have been calls for more empirically grounded perspectives that focus on what standards actually do at the street level of healthcare practice. As a key 
example, the emerging sociology of standardisation ${ }^{1}$ (Timmermans and Berg 2003; Timmermans and Epstein 2010) seeks to complement traditional ‘top-down’ perspectives (in which guidelines are seen simply as blueprints to be implemented) with a 'bottom-up' perspective, focussing on how guidelines are actually used in clinical practice. Drawing on insights from interactionism and science studies, these ‘sociologists of standardisation' warn against the idea of guidelines as "one uniform thing, with one uniform effect” (Timmermans and Berg 2003: 23). Instead, they argue that the sociological import of standards "comes out most clearly through scholarship that is specific, empirical, and located in concrete social settings” (Timmermans and Epstein 2010: 84).

In the case of triage, some bottom-up studies have explored how triage nurses make use of guidelines in their assessments (see article 1 in this dissertation for a more thorough review). One common finding is that triage nurses' priority setting relies on more than guidelines, which are seen as an insufficient basis for decision making (cf. Fry and Burr 2001; Gerdtz and Bucknall 2001). However, most of these studies explore telephone triage, which differs in many ways from the face-to-face EMS encounter (cf. O’Cathain et al. 2004). Furthermore, with a few exceptions (Greatbatch et al. 2005; Russell 2012; Tjora 2000), most such studies provide rather thin descriptions of both guidelines and how nurses relate to them, making it hard to judge the interplay between these factors. Similarly, while many studies show that nurses depart from guidelines, few provide any thorough explanation of how and why they do so. Finally, in focusing almost exclusively on nurses' departures from guidelines, most studies neglect how guidelines may potentially influence nurses’ assessments. It seems, then, that more research is needed on standardisation in triage.

Informed by the sociology of standardisation, this dissertation represents a bottom-up exploration of the relationship between standardisation and discretion in the priority setting of EMS triage nurses. During nine months of ethnographic fieldwork in a large-scale Norwegian emergency primary care clinic (EPCC; 'legevakt' in Norwegian), I observed and interviewed nurses about their triage assessments. Nurses in the EPCC were required to assess patients using the Manchester Triage System (MTS), which is currently the most widely used triage system in Europe (Mackway-Jones et al. 2014). In general, EPCC staff viewed the MTS as a

\footnotetext{
${ }^{1}$ Timmermans and Epstein (2010) refer to 'the sociology of standards and standardisation', but for simplicity, I refer here to 'the sociology of standardisation'.

2 EPCCs are also referred to as 'out-of-hours emergency primary health care services' (cf. Raknes and Hunskaar 2017); for simplicity and clarity, I prefer 'emergency primary care clinics’, not least because many EPCCs are open $24 / 7$.
} 
well-functioning system; indeed, one physician counselled that there was no need to study triage at this clinic, as the MTS ensured standardised assessments. However, my observations of triage nurses’ practice revealed a different and more complex story, as nurses regularly departed from the MTS while also being influenced by it in a number of ways. From this point of departure, the dissertation addresses the following general research question:

- What is the relationship between standardisation and discretion in triage nurses' priority setting?

To this end, the dissertation addresses three more specific questions.

- (1) How and (2) why do triage nurses depart from the MTS when prioritising patients?

- (3) How does the MTS influence nurses’ priority setting?

These research questions are answered in the following four articles (summarised more thoroughly in Chapter 5):

1. 'Beyond guidelines: Discretionary practice in face-to-face triage nursing'. This article explores nurses' discretionary application of the MTS, detailing how nurses' assessments were at odds with MTS prescriptions and how their reasoning led them to override guidelines by both overt and covert means.

2. 'Workplace assimilation and professional jurisdiction: How nurses learn to blur the nursing-medical boundary'. This article details how nurses develop the knowledge underpinning the discretionary practice described in article 1.

3. 'Narratives and gatekeeping: Making sense of triage nurses' practice'. This article focuses on a particular discretionary practice: how, in contravention of guidelines, nurses work to turn 'trivial' patients away from the EPCC. Combining observations and narrative analysis, it reconstructs their reasons for engaging in this discretionary gatekeeping.

4. 'The commensuration of pain: How nurses transform subjective experience into objective numbers'. This article highlights nurses' pain scoring, a mandatory aspect of the MTS. After accounting for why nurses disregarded patients' self-reported pain scores - in violation of the guidelines and despite believing that pain is a subjective phenomenon - the article goes on to reconstruct the main principles, methods and beliefs underlying nurses’ ‘objective’ approach to pain scoring. 
Together, these articles provide a comprehensive analysis of the relationship between standardisation and discretion in triage. They show how nurses supplemented the MTS with additional skills and knowledge, and how this led them to adjust or override the priorities formally prescribed by the MTS. While they had several reasons for doing so, their primary concern was to 'correct' the MTS and to ensure more precise prioritisation of patients. However, the MTS also played a significant role in their assessments by restricting, enabling and supporting their priority setting.

Beyond accounting for triage nurses' discretionary priority setting, this dissertation also makes three more general contributions to the sociology of standardisation. First, the in-depth exploration of nurses' use of the MTS provides a rich account of the difficulties of streamlining clinical practice. Despite its elaborate design, the MTS was too 'thin' to match the complexity of triage nurses' work, and to follow it unreflectively would have been to the detriment of both patients and staff. For that reason, nurses found it necessary to render the guidelines 'thicker' by making situated judgments, illustrating the crucial role of additional skills and knowledge in making standards work.

Secondly, the dissertation shows how, despite its shortcomings, the MTS affected nurses' work in a series of ways, so answering Timmermans and Berg's (2003) call for further research on how guidelines interact with professional practice. By transcending the either/or language that characterises much research on standardisation, the dissertation provides a nuanced illustration of the interplay between prescribed and discretionary aspects of triage nursing.

Finally, the dissertation also contributes to bridging the gap between the sociology of standardisation and the literatures on categorisation and street-level bureaucracy. Theories of categorisation (cf. Kövecses 2006; Zerubavel 1991) help to conceptualise the relationship between guidelines and nurses' practice by framing the MTS as a standardised system for sorting patients into categories of urgency, and to explore the relationship between formal and informal aspects of triage nurses' categorisation of patients. Additionally, theories of streetlevel bureaucracy (cf. Lipsky 1980) offer a rich framework for understanding the relationship between workers, standards and organisations, especially when studying the standardisation of professional work in street-level organisations. In bringing these literatures together, the dissertation identifies fruitful theoretical linkages for the study of standardisation and discretion in such settings. 


\section{Roadmap}

The rest of this introduction is organised as follows.

- Chapter 2 outlines some key contextual factors related to triage and the Norwegian healthcare system.

- Chapter 3 describes the theoretical framework. Combining insights from the sociology of standardisation, street-level bureaucracy and categorisation, this facilitates exploration of the relationship between standardisation and discretion in triage nurses' street-level categorisation of patients.

- Chapter 4 discusses the data and methods in greater depth, including the rationale for choosing an ethnographic methodology. The study setting is described in detail, followed by an account of how the fieldwork was carried out. The chapter closes with a discussion of ethical considerations and data analysis.

- Chapter 5 briefly summarises the four articles on which the dissertation is based.

- Chapter 6 reviews in more detail what these articles tell us about the relationship between standardisation and discretion in triage, as well as in street-level professional work more generally. The chapter concludes with a discussion of some limitations and possible avenues for future research. 


\section{Chapter 2: Study context}

This chapter situates the study in its empirical context, outlining the role of EPCCs in the Norwegian healthcare system before discussing triage nursing and its standardisation. The chapter also provides an overview of the MTS - the triage system used in the study setting.

\section{EPCCs in the Norwegian healthcare system}

The Norwegian healthcare system is largely publicly funded, with public sources accounting for approximately $85 \%$ of total health expenditure and the remaining $15 \%$ coming mainly from out-of-pocket payments (Ringard et al. 2013: xviii). Its healthcare services are divided between primary and specialist care; as emergency primary care clinics, EPCCs are assigned to the former. While specialist care is organised at state level, primary care is administered at municipal level.

As compared to most other Western countries, Norway places special emphasis on primary care for emergencies, and this gives EPCCs a central role in the Norwegian healthcare system (Hansen and Hunskår 2016). With the exception of clear-cut emergencies, all patients with acute complaints must first seek help at an EPCC or other primary care provider (such as a general practitioner (GP)). ${ }^{3}$ Only after this are they referred (if necessary) to an emergency department (ED) or other specialised care services. This means that Norway's EPCCs undertake much of the initial screening performed by EDs in most other Western countries (Vassy 2014).

Norway has 191 EPCCs covering approximately 5.3 million people across 422 municipalities. In total, EPCCs complete approximately 1,300,000 consultations each year-a rate of 262 consultations per 1000 citizens (Hansen and Hunskår 2016: 39, 42). As Norway is one of Europe's most sparsely populated countries, EPCCs range in scale from a single physician on call (in rural areas) to large organisations employing hundreds of workers. Most EPCCs are relatively small, with only a few workers, but a centralising trend towards larger (and often inter-municipal) institutions means that the large-scale variant is becoming more common (Hansen and Hunskår 2016). As Norway’s municipalities have considerable freedom in how they organise their health services (Ringard et al. 2013: xviii), there has been some concern for the way EPCCs are run. For instance, two reports published by The National Centre for

\footnotetext{
${ }^{3}$ Overall, Norwegian emergency primary care services include EPCCs, the regular general practitioner scheme, emergency medical communication centres, car- and helicopter-based ambulance services, home nursing care and municipal 24-hour units ('kommunal akutt døgnenhet') (NOU 2015: 9).
} 
Emergency Primary Health Care (2009, 2014) criticised what they saw as haphazard variation between municipalities, as well as a lack of quality assurance and problems with recruitment.

Patient influx differs significantly between small- and large-scale EPCCs. While most smaller EPCCs report that queueing is rare or non-existent (Hansen and Hunskår 2016: 152), waiting times in the largest urban clinics can extend to several hours, making them more prone to the (over)crowding described in the international literature (Carter et al. 2014; MacDonaldNethercott et al. 2016; Pines et al. 2011). Commonly cited reasons for this large influx of patients include steady population growth, problems with the regular general practitioner scheme, patients' changing expectations, cheap consultations (individual rates start at about $£ 20$ ), short travelling distance, and the fact that patients can walk in at their own discretion (cf. Hansen and Hunskår 2016; The Norwegian Medical Association 2015). Whatever the reasons, urban EPCCs face significant challenges in matching available resources to patient demands, and triage nurses play a key role in this regard.

\section{Triage}

Triage stems from the French verb trier, which means to 'pick', 'sort' or 'select' (Bruce and Suserud 2005). The term was originally used to refer to the sorting of items such as wool and coffee beans according to their quality, ${ }^{4}$ but it is now associated primarily with the sorting of patients according to medical urgency (Iserson and Moskop 2007: 275). This usage can be traced back to military medicine, and in particular to Napoleon's chief surgeon, Baron Dominique Jean Larrey, who made two critical contributions to the field. The first was the 'flying ambulance', a light carriage that allowed patients to be evacuated and treated during combat (in contrast to earlier times, when they had to wait until the battle ended before being treated). The second was an egalitarian principle for prioritising the wounded, as specified in his 1812 memoirs on the Russian campaign: “Those who are dangerously wounded should receive the first attention, without regard to rank and distinction. They who are injured in a less degree may wait until their brethren in arms, who are badly mutilated, have been operated on and dressed" (cited in Iserson and Moskop 2007: 277). Although he did not refer to this as 'triage', this formulation emphasised the need to prioritise patients based on medical (rather than e.g. status-related) urgency. ${ }^{5}$

\footnotetext{
${ }^{4}$ Given its etymology, the former director of The Language Council of Norway argued that the word 'triage' was dehumanising (Sykepleien 2009: 42); this is not, however, a prevalent view in the Norwegian context.

${ }^{5}$ Larrey’s principles were later modified; for instance, it was argued that some patients can be too dangerously wounded to be prioritised for treatment, and that the order of priority is therefore better determined according to one’s prospects for recovery (Iserson and Moskop 2007).
} 
During the last century, triage systems have been developed for use in a range of different contexts, including multi-casualty incidents, disasters, battlefields, telemedicine and walk-in EMS organisations (Iserson and Moskop 2007). In some contexts, resources may be so scarce that triage assessments determine who lives and who dies. In EMS organisations, however, the available resources typically allow for every patient to be treated, ${ }^{6}$ and triage systems are therefore used mainly for frontline screening of patients according to medical urgency.

EMS triage systems were first introduced in the US in the late 1950s, when patient attendance increased and one might have to wait several hours to see a physician (Gilboy et al. 1999: 468). Since then, nurses have been largely responsible for implementing triage systems, and the term ‘triage nursing' has become commonplace (FitzGerald et al. 2010; Iserson and Moskop 2007). Walby and Greenwell (1994: 86) argued that triage nursing challenges the traditional boundaries between nursing and medicine in allowing nurses to undertake assessments that resemble physicians' consultations. However, as triage nurses are required to follow standardised triage systems, formal professional boundaries remain largely intact.

For a long time, triage depended on organisation-specific systems that varied widely in design. However, the introduction of general triage systems in the 1990s aimed to standardise assessments across EMS organisations (FitzGerald et al. 2010). These systems include the Australasian Triage Scale (ATS), the Canadian Triage and Acuity Scale (CTAS) and the aforementioned MTS, which are now the national standard in their country of origin (Australia, Canada and the UK, respectively). Among other things, most triage systems specify a common nomenclature, a fixed number of urgency categories into which patients should be sorted, instructions for how to sort patients within these categories and how long the maximum waiting time should be for patients in each category (FitzGerald et al. 2010).

In Norway, the introduction of standardised triage systems followed in the wake of a highly critical report from the Norwegian Board of Health Supervision (2008), which stated that frontline screening in EDs was varied and often haphazard. While this prompted both EDs and larger EPCCs to standardise their triage assessments (Halvorsen et al. 2014: 13-4), there is no agreed standard in Norway. ${ }^{7}$ Different organisations use different systems, such as the MTS, the Rapid Emergency Triage and Treatment System (RETTS) and the Norwegian Index

\footnotetext{
${ }^{6}$ This is not to say that every patient will be seen by a physician, as long waiting times can deter even the most patient of patients.

${ }^{7}$ While there have been calls for a unified triage system for all Norwegian emergency services, many consider this problematic because of the heterogeneity of needs across services and municipalities (Halvorsen et al. 2014: 53-9).
} 
for Medical Emergency Assistance ('medisinsk indeks') (Halvorsen et al. 2014: 17-24). The next section briefly outlines the MTS, which was used in the EPCC under study.

\section{MTS}

The MTS was developed in the mid-1990s by a group of emergency physicians and nurses in the UK, collectively known as the Manchester Triage Group. They sought to rectify the fragmented state of UK emergency services, as organisations were using different triage systems, each with its own nomenclature, principles and design. In 1997, MTS was adopted as the national standard in the UK, and it was introduced in Norway in 2010. Today, it is the most widely used triage system in Europe (Mackway-Jones et al. 2014).

The MTS is a paper-based manual comprising 53 flow charts, ${ }^{8}$ organised by 'chief complaints' such as allergy, ear problems, head injury and back pain (the example shown in Figure 1). Patients are assessed one by one. Nurses are instructed to ask about their main problem and to select the chart that most closely corresponds to this. Each flow chart lists between 13 and 32 'discriminators' - that is, clinical signs and symptoms related to the chief complaint. While 'specific' discriminators relate exclusively to a particular complaint, 'general' discriminators appear across many or most charts and include

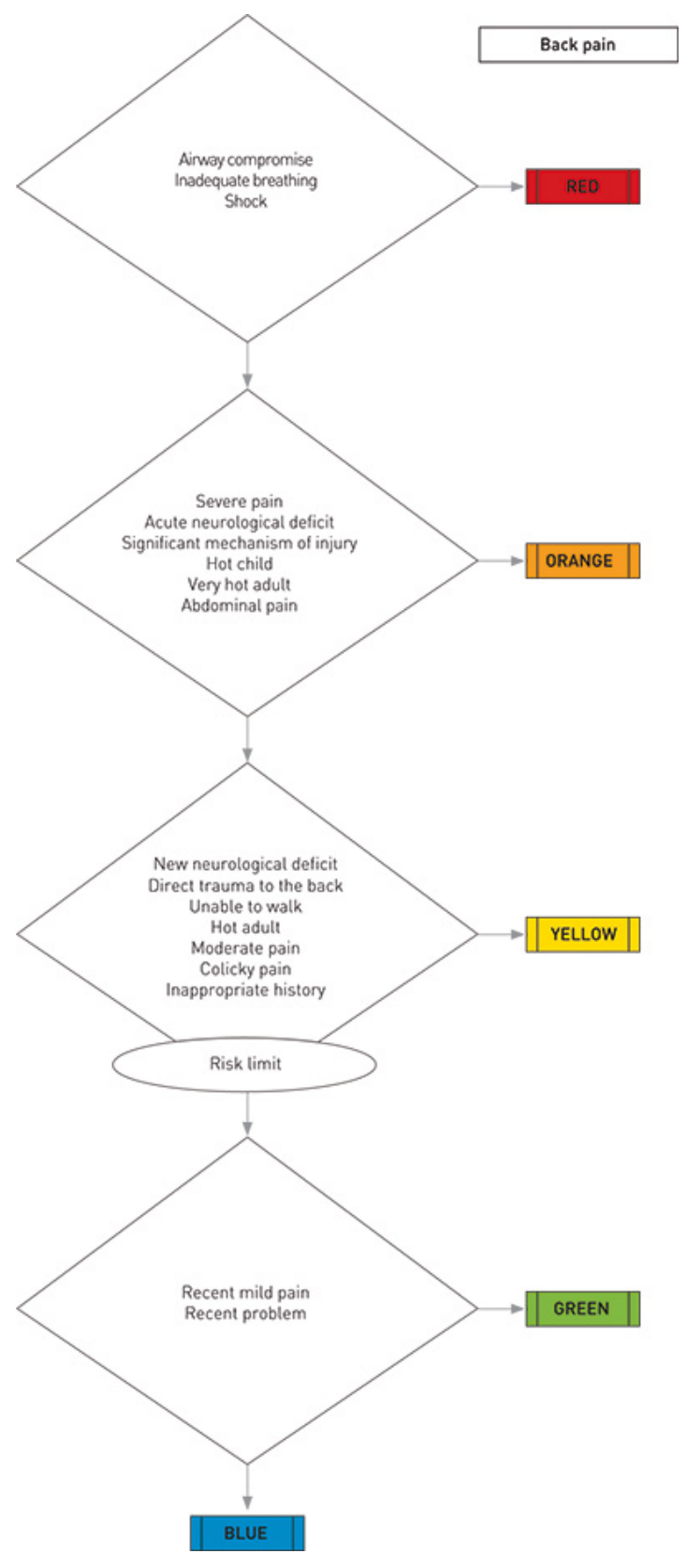

Figure 1: The MTS flow chart for 'Back pain'. signs related to six areas: 'life threat', 'consciousness level’, 'haemorrhage', 'temperature’, 'pain' and 'acuteness'. Within each chart, discriminators are ordered in a hierarchy of five colour-coded 'urgency levels' or 'triage codes', ranging from red (most urgent) to orange, yellow, green and blue (least urgent). After selecting a flow chart, the triage nurse is supposed

\footnotetext{
${ }^{8}$ While this seems a low number, the 53 include residual categories (such as 'Unwell adult' and 'Unwell child') that can be applied to anyone who does not fit any of the more specific charts.
} 
to start from the top of the chart and to rule out discriminators one by one until they find a positive match, which should determine the patient's triage code. As an extra safety measure, many charts include a 'risk limit', below which the nurse should not go unless absolutely certain that the above discriminators have been ruled out. The top three codes specify maximum waiting times; red patients should receive immediate medical attention while orange and yellow patients should see a physician within ten or sixty minutes, respectively (Mackway-Jones et al. 2014). (See Appendices 1 and 2 for more extensive excerpts from the triage manual.)

The MTS it is a licensed system, and to ensure consistent use, the Manchester Triage Group requires organisations to complete a series of formal steps before implementing it. In Norway, the Norwegian Manchester Triage Group oversees the implementation process. Among other requirements, potential triage nurses must attend a full-day course led by certified triage instructors; they must also read the official MTS book (Mackway-Jones et al. 2014) ${ }^{9}$ and practise using the system under the supervision of a triage instructor. Nurses must have some EMS experience before attending the course, and organisations are expected to regularly audit triage assessments. Furthermore, while organisations may supplement the system (by adding certain symptoms and signs of concern), they are not allowed to formally alter any of the MTS flowcharts. These measures are intended to ensure consistent application of the system. According to the preface of the MTS book, the system is intended as a 'source reference and aide-memoire' (Mackway-Jones et al. 2014: xi); it further states that practitioners should use the MTS 'to inform the triage process and ensure that their decisions are both valid and reproducible' (Mackway-Jones et al. 2014: xi, my italics). After the foreword, however, there is less emphasis on this optional character. In the clinic under study, there seemed to be some acceptance that nurses may supplement the system in order to upgrade a patient's triage code to a higher one than prescribed by the MTS. Other than in clear-cut cases, however, it was significantly less acceptable to downgrade patients to a lower one than the MTS prescribes. Regardless of the legitimate level of discretion, the findings of this dissertation show that nurses went well beyond system prescriptions. The nature of these discretionary practices and the reasons for them are elaborated in Chapters 5 and 6, as well as in the associated articles.

\footnotetext{
${ }^{9}$ At the time of the reported fieldwork, the EPCC was using the 2011 version of the Norwegian MTS book (Manchester Triage Group 2011). A new edition has subsequently been released (Manchester Triage Group 2015), but this mainly adjusts some discriminator descriptions and flow charts, without changing the overall logic of the system.
} 


\section{Chapter 3: Theoretical framework}

This chapter elaborates the theoretical framework used to explore the relationship between standardisation and discretion in triage nurses' priority setting. The framework combines insights from three overlapping literatures: the sociology of standardisation, street-level bureaucracy, and categorisation. The following sections will present these in turn.

\section{The sociology of standardisation}

The need for a sociology of standardisation was made explicit in an article in the Annual Review of Sociology (2010) by Stefan Timmermans and Steven Epstein. Their point of departure was the observation that modern life "increasingly depends on the creation, institutionalization, use, and dissemination of diverse kinds of standards” (Timmermans and Epstein 2010: 70), and that this warrants more intensive study by sociologists. While acknowledging the breadth of existing research scrutinising standards (mostly associated with the field of science studies, see Berg 1997b; Casper and Clarke 1998; Fujimura 1992; Hogle 1995; Jordan and Lynch 1998; Latour and Woolgar 1986; Timmermans and Berg 1997, 2003), they argued that sociology could benefit from more explicit and systematic inquiry into the role of standards in modern societies. A key reason for this is that standards are often perceived as 'boring things' (Lampland and Star 2009: 11) and are therefore at risk of being neglected; indeed, standards are "such widespread and omnipresent features of modernity that, ironically, their precise sociological significance stands at risk of vanishing out of sight” (Timmermans and Epstein 2010: 84).

As defined by Timmermans and Epstein, standards aim "to render the world equivalent across cultures, time, and geography” (2010: 69). In this general sense, standardisation is arguably as old as society itself; for instance, the consolidation of the Chinese state in 221 BCE depended on the standardisation of language and culture (Fukuyama 2012). Modern interest in standardisation can be traced to the Enlightenment view that uniformity results in predictability, accountability and objectivity (Timmermans and Berg 2003: 8), and standardisation gained particular momentum from the middle of the nineteenth century onward, in conjunction with the increased internationalisation of industry, business, and trade (Brunsson and Jacobsson 2000). These changes were noted in many classical sociological works, such as Marx’s (1867) studies of the commodification of labour and Weber's (1930, 1983) analysis of the rationalisation of Western societies. Since then, standardisation efforts have accelerated—often with the support of external bodies such as the state, professional 
organisations and manufacturers' associations - and standards and standardisation have become ubiquitous in modern societies (Timmermans and Epstein 2010: 71).

A distinction is often drawn between four subtypes of standards (Timmermans and Berg 2003: 24-6; Timmermans and Epstein 2010: 72). Design standards define the properties and features of products and tools (e.g. the width of railroad tracks or the size of injection needles); terminological standards establish common nomenclatures (e.g. classification systems such as the International Classification of Diseases); performance standards specify desired outcomes (e.g. the maximum time a patient should wait within each triage category); and procedural standards specify how processes should be performed, step by step.

According to Timmermans and Berg (2003: 13), contemporary healthcare in particular has seen an increased emphasis on procedural standards, of which the MTS is one example. As mentioned, procedural standards are championed mainly by proponents of evidence-based medicine in their mission to ensure that clinical practice is informed by the best scientific evidence (Knaapen 2014; Mykhalovskiy and Weir 2004; Timmermans and Berg 2003; Weisz et al. 2007). ${ }^{10}$ Following Berg's (1997a) definition, such standards include

a set of instructions telling medical personnel to do A in situation B. These instructions may be more or less elaborate, precise, or binding; they may be formatted in different ways, and may have been construed in an off-handed or in a highly structured way-but they all share this common feature. They may be elaborately designed as a detailed flow-chart, or they may consist of a number of rather vague and general recommendations, but they all guide medical personnel through a sequence of steps. (Berg 1997a: 1081)

While proponents see procedural standards as a key means of reducing the risks associated with discretionary decision making (Ruston 2006), some scholars have expressed concern that the introduction of guidelines may contribute to the bureaucratisation of clinical work. As early as the 1990s, for instance, Freidson remarked that "The health-care system of today is best made sense of as a mix of the bureaucratic and professional models, with elements of the former rapidly growing in importance as the administrative structure surrounding practice expands” (1994: 192). These developments have been derogated as 'cook-book medicine' (Harrison 1998; Hunter 1996), suggesting that clinicians are merely following recipes without critical reflection. In similar vein, it has been argued that standards contribute to the homogenisation of healthcare work, with patients’ problems addressed in generic, assembly-

\footnotetext{
${ }^{10}$ While most closely associated with evidence-based medicine, similar standards are also found in fields such as engineering (Shapiro 1997) and law (Lynch 2018).
} 
line fashion (cf. Ritzer 1993). Others have argued that, by allowing outsiders access to the esoteric system of professional knowledge, the introduction of procedural standards contributes to a process of ‘deprofessionalisation’ (Haug 1975, 1988).

While open to the relevance of these macro-scale accounts, the sociologists of standardisation have cautioned against such totalising statements. Rather than viewing guidelines as implemented top-down 'from an omnipotent centre' (Evans and Harris 2004: 885), they advocate a complementary bottom-up perspective, focusing on how guidelines are actually used (or not) by those responsible for implementing them. As they see it, abstract guidelines must always be translated into situated practice, and this translation involves a range of potential contingencies. Accordingly, as the implementation and effects of guidelines may vary across settings, studies of standardisation will benefit from situated analyses on a caseby-case basis (Timmermans and Epstein 2010: 84). Clearly, such studies may still corroborate the critics’ warnings about bureaucratisation, homogenisation and deprofessionalisation. Equally, it may emerge that guidelines do little to diminish-and may even increase (Berg et al. 2000)_professional discretion (see also Gabbay and le May 2011). In any event, the important point is to resist making a priori assertions about the effects of guidelines, instead investigating them empirically, from the bottom up.

\section{Street-level bureaucracy}

In its bottom-up stance, the sociology of standardisation closely resembles theories of streetlevel bureaucracy (Lipsky 1980; for overviews, see Brodkin 2012; Hupe et al. 2015; Maynard-Moody and Portillo 2010; Meyers and Lehmann Nielsen 2012; Smith 2012). While these fields have not (to the best of my knowledge) previously been linked, I contend that the street-level perspective has much to offer studies of standardisation, especially in its focus on organisational characteristics and its understanding of discretion.

The theory of street-level bureaucracy was first formulated by Michael Lipsky (1971, 1980). Observing the malfunctioning of US public services in the 1960s and '70s, Lipsky set out to understand why public workers were failing to comply with the goals set by policy makers. However, unlike the usual top-down explanations attributing such failures to unruly or incompetent workers, his bottom-up perspective examined policy from the perspective of those delivering it at the frontline. This approach has been adopted in a range of subsequent studies, exploring the street-level work of occupational groups such as social workers (Evans and Harris 2004; Keiser 2010), the police (Buvik 2016; Maynard-Moody and Musheno 2003), 
politicians (May and Winter 2009), teachers (Maynard-Moody and Musheno 2003; Taylor 2007), liquor inspectors (Wilkinson and MacLean 2013) and nurses (Hoyle 2014; Walker and Gilson 2004). To the best of my knowledge, this is the first study to subsume triage nurses under the umbrella of street-level bureaucrats. ${ }^{11}$

According to Lipsky, street-level bureaucrats are "public officials who grant access to government programs and provide services within them” (1980: 3). Beyond this, they share at least two defining traits: First, they have substantial discretion in how they carry out their work, and second, they interact directly with citizens (Lipsky 1980: 3). The first point, discretion, is often seen as the quintessence of street-level bureaucrats' work, which follows in part from the understanding that street-level bureaucracy is an organisational model for dealing with complex human needs that elude simple rules and distinctions (Prottas 1979: 91). It is worth noting, however, that Lipsky has been criticised for ignoring differences in discretion between lower-level workers (such as receptionists and clerks) and paradigmatic professionals (such as lawyers and physicians) (Evans 2011: 371-3). While Lipsky (cf. 1980: 14) would rightly contend that all street-level bureaucrats exercise greater discretion than their job description might suggest, I agree about the relevance of inter-occupational differences, as those considered professionals (including the nurses in the present study) ${ }^{12}$ are generally permitted greater discretion in their work (Evans 2011: 371-3).

On the second point, direct interaction means that street-level bureaucrats serve as the interface between government and the citizen (Brodkin 2015: 29). Prottas claimed that streetlevel bureaucrats “operate simultaneously in two interdependent worlds” (1979: 87): the internal world of organisational rules, categories and procedures and the external world of client information and demands. While management and clients are restricted to either the internal or the external world, respectively, street-level bureaucrats have routine access to both, giving them a unique ‘boundary-spanning role’ (Prottas 1979: 87).

In addition, most studies emphasise how street-level bureaucrats often work under challenging conditions, as they are chronically under-staffed and must balance the conflicting

\footnotetext{
${ }^{11}$ Interestingly, Lipsky briefly mentioned the concept triage in his book—at one point even claiming, "Triaging provides a useful analogy for bureaucratic differentiation” (1980: 106, see also 198). Prottas (1979) also deserves mention, as he analysed the street-level work of the emergency room clerk-a role similar to the triage nurse, but occupied by workers with less healthcare education.

${ }^{12}$ Much ink has been spilled over the concept 'profession' and whether this or that occupation - including nursing - should be subsumed under this label (cf. Abbott 1988: 3-9; Etzioni 1969). When I use the concept in this dissertation, it is mainly to denote that nurses have a shared educational background and knowledge base, and that nursing has largely succeeded in establishing a public image as a profession in Norway (Lund 2012).
} 
expectations of clients, management and government (cf. Hupe et al. 2015). Maynard-Moody and Musheno described them as the 'coal miners' of policy, doing "the hard, dirty and dangerous work of the state” (2003: 157). To simplify decision-making and to make their jobs more manageable, street-level bureaucrats tend to develop routines, shortcuts and simplifications for the processing of clients (Lipsky 1980: 83-5). Although not mentioned in guidelines or other formal documents, these can have significant influence on how policy is delivered and, ultimately, on clients’ life chances.

Contrary to popular perception, then, street-level bureaucrats may exercise significant power within their organisation. Indeed, their discretionary, boundary-spanning role affords them substantial influence on how 'policy as written' is transformed into 'policy as performed' (Lipsky 1980: xvii). On that basis, Lipsky (1980) argues that the aggregate actions of streetlevel bureaucrats ultimately define the policies of the organisations they represent.

If we replace 'policies' with 'guidelines' or 'standards', the street-level perspective seems largely congruent with the sociology of standardisation, as both advocate a bottom-up perspective to "open up the black box of what literally happens in implementation organisations” (Hupe et al. 2015: 9). Rather than assuming any straightforward form of implementation from top to bottom, the point is to explore how formal structures are enacted and negotiated in everyday practice. In the words of Evans and Harris, "Policy, like any text, is not fully under the control of its authors” (2004: 886).

Some differences can also be noted; among these, studies of street-level bureaucracy extend beyond sociology, encompassing such disciplines as political science and management studies (cf. contributors in Hupe et al. 2015). Studies of street-level bureaucracy have also tended to rely on interviews rather than on ethnographic approaches, although there has been a recent 'ethnographic turn’ (Brodkin 2008, 2012), to which this dissertation contributes.

Importantly, some researchers have questioned whether discretion remains a defining aspect of street-level bureaucracies (cf. Howe 1991; Lymbery 1998, 2000)_for instance, it has been argued that social work is being "transformed from a self-regulating professional activity into a managed and externally regulated set of tasks” (Jones et al. 1999: 38), where increased internal and external regulation leave workers with virtually no scope for autonomous judgment. However, like the sociologists of standardisation, many researchers under the street-level umbrella are sceptical about such totalising claims (cf. Evans and Harris 2004). To 
get a better understanding of their shared scepticism, it is useful to take a closer look at what these two perspectives tell us about discretion.

\section{Discretion}

As we have seen, discretion is a defining characteristic of street-level bureaucracy. ${ }^{13}$ Although less often invoked, the concept is also central to many of the sociology of standardisation's theoretical underpinnings. As the two perspectives draw on somewhat different but complementary literatures and understandings, there is much to be gained by approaching them as a whole.

Etymologically, the English word discretion derives from the Latin word discretus, a form of the verb discernere, which translates as to ‘separate', 'discern’ or 'distinguish’ (Molander 2016: 7). ${ }^{14}$ In studies of street-level bureaucracy (cf. Hupe et al. 2015: 7), reference is often made to the philosopher Dworkin (1978) and his understanding of discretion as a space of autonomous decision-making surrounded by a belt of restrictions. On this definition, discretion does not suggest an absence of restrictions, only that the restrictions leave some scope for the actor's own judgment. Dworkin famously likened discretion to "the hole in a doughnut”, as it “does not exist except as an area left open by a surrounding belt of restriction” (1978: 31). Following Dworkin’s definition, restrictions are constitutive of, rather than antithetical to, discretion; there is no point in speaking of discretion other than in relation to someone being "charged with making decisions subject to standards set by a particular authority” (Dworkin 1978: 31). Dworkin’s definition further stresses that the size of one's discretionary space is defined as a matter of degree, relative to the surrounding restrictions (see also Evans and Harris 2004). It follows that the concept of discretion is continuous rather than dichotomous.

While the continuous understanding of discretion is widely accepted, some have felt it necessary to nuance the understanding of discretion as delegated (as implicit in Dworkin's emphasis on being “charged with making decisions” (1978: 31) ${ }^{15}$ ). Referring to Dworkin’s definition as 'de jure discretion' — that is, as “the official recognition of a right or entitlement to decide” (Evans 2010: 33)—Evans contrasts this with ‘de facto discretion', defined as

\footnotetext{
${ }^{13}$ Discretion is also often considered the quintessence of professional work more generally (cf. Freidson 2001).

${ }^{14}$ This bears a remarkable resemblance to the word triage, meaning to sort or select (Bruce and Suserud 2005).

${ }^{15}$ It should be noted that Dworkin did not view discretion only as delegated. As Evans and Harris wrote,

"Dworkin identified three senses of discretion: judgment that has to be employed to apply a standard (in circumstances where judgment cannot be applied mechanically); the final responsibility for making a decision (within the rules); and discretion in a strong sense, which gives the decisions and the criteria of decision making to professionals" (2004: 881).
} 
"having the power to act, though not necessarily officially recognised" (2010: 33). This is arguably a crucial distinction for studies of street-level bureaucracy, given their interest in how policy is enacted de facto on the ground floor of public service delivery.

In accounting for the gap between de jure and de facto discretion, studies of street-level bureaucracies place great emphasis on the characteristics of organisations, rules and the relationship between the two. Among other things, management often allow workers some leniency because they depend on their cooperation; as Lipsky puts it, "Workers can punish supervisors who do not behave properly toward them, either by refusing to perform work of certain kinds, by doing only minimal work, or by doing work so rigidly as to discredit supervisors” (1980: 24-5). Moreover, rules and guidelines can vary significantly in how strictly, unambiguously and exhaustively they prescribe practice (Evans and Harris 2004), sometimes leaving significant room for discretion (cf. Buffat 2015). As most street-level bureaucrats work under little direct supervision, they can also exercise significant autonomy, even if management requires them to adhere to 'strict' guidelines, as long as their deviations cannot be detected (cf. Prottas 1979: 12).

Additionally, the sociologists of standardisation tend to ground their understanding of discretion in the finitist perspective first formulated by Wittgenstein (1953). ${ }^{16}$ On this view, general rules and guidelines can never exhaustively or definitively prescribe what to do in a particular case. As generalisations, rules are always ‘thin' as compared to the richness of their field of application. For one, there will always be contingencies that elude formal rules and regulations. ${ }^{17}$ Furthermore, even where rules are available, they are always supported by unstated, conventional agreements about their scope and applicability; should we attempt to explicate all these unstated agreements, we would inevitably be caught in an infinite regress (Garfinkel 1967; Heritage 1984). As Strauss (1963) put it, rules

\footnotetext{
always require judgment concerning their applicability to the specific case. Does it apply here? To whom? In what degree? For how long? With what sanctions? The personnel cannot give universal answers; they can only point to past analogous instances when confronted with situations or give "for instance” answers, when queried about a rule’s future application. (Strauss et al. 1963: 153)
}

\footnotetext{
${ }^{16}$ The finitist perspective was later elaborated in ethnomethodology (Garfinkel 1967; Heritage 1984) and in the so-called sociology of scientific knowledge (cf. Barnes et al. 1996: 54-9; Bloor 1997).

${ }^{17}$ As Garfinkel argued, this applies even to simple games such as ticktacktoe: "Say we are going to propose a game of ticktacktoe. Two persons play ticktacktoe. Any two persons? When, today? Tomorrow? Do we have to be in sight of each other? Can we play by mail? Can one player be dead?” (1968, 211-12; cited in Heritage 1984: 125)
} 
The finitist perspective reminds us, then, of the inevitable need for discretion when bridging the gap between 'thin' rules and 'thick' circumstances. By implication, it would be impossible to fully eradicate discretion (Heritage 1984: 120-9).

In similar fashion, some studies of street-level bureaucracy also emphasise the insufficiency of rules in prescribing conduct. Consider, for instance, the following claim by Evans and Harris (2004):

Street-level bureaucrats frequently find themselves in circumstances in which they have to make sense of these rules and procedures and, in applying them, have to interpret them, a situation that involves them in effectively making policy. The nature of human services can also throw up situations for which policy has not yet been developed and which result in street-level bureaucrats having to decide policy for themselves. (Evans and Harris 2004: 879)

Clearly, there is a significant overlap between these two perspectives in their view of formal structure and informal practice. While both acknowledge that street-level practice always occurs within a framework shaped by law, policy, managers and broader cultural structures, they consider it an unwarranted assumption "to present this framework as coherent, complete and unambiguous and as being understood in exactly the same way by all those involved with it” (Evans and Harris 2004: 887).

It is against this background that Timmermans and Epstein argue that the sociological importance of standards "comes out most clearly through scholarship that is specific, empirical, and located in concrete social settings” (2010: 84). Depending on how they are implemented and enforced at a particular site, standards can have multiple and varying effects. Accordingly, Timmermans and Epstein (2010) also urged researchers to keep an open mind when studying standards; rather than confining their questions to 'whether' or 'how much' guidelines influence practice, we should ask where, when, how and to what extent standards matter, and we should remain open to finding different answers on a case-to-case basis. ${ }^{18}$ That stance informs the present exploration of standardisation in triage nursing.

\section{Priority setting qua categorisation}

Having clarified the dissertation's perspective on standardisation and discretion, we now zoom in on the practice under study: priority setting. Also referred to as prioritisation and rationing, priority setting denotes the allocation of scarce resources, which occurs at the

\footnotetext{
${ }^{18}$ As Rock argues, "The standardization and comparability of social phenomena must always be in doubt. A university in Colorado or Calcutta is not necessarily the same as one in Cambridge, Massachusetts or Cambridge, England” (2001: 30).
} 
macro, meso and micro levels of healthcare (cf. Schmidt 2004: 969). Macro-level concerns include how much of the national budget is used for healthcare as compared to other sectors and interests; meso-level concerns include how healthcare organisations allocate their resources between alternative activities; and micro-level concerns include the allocation of scarce resources to individual patients (also called bedside rationing, see Ubel and Goold 1997).

This dissertation focuses primarily on the micro-level priority setting of triage nurses. Moving one step up the ladder of abstraction, we can conceptualise this as a form of categorisation, as it involves the sorting of patients into categories of more or less urgency. ${ }^{19}$ In so doing, we can link studies of prioritisation to the much broader research tradition of categorisation. This research dates back (at least) to Durkheim and Mauss' $(1903,1969)$ analysis of 'primitive classification' and has subsequently extended to areas that include social cognition (Fiske and Taylor 2013; Zerubavel 1997); information systems (Bowker and Star 1999); organisational culture (Ashforth and Humphrey 1997; Vergne and Wry 2014); cultural classification systems (Douglas 1966); labelling theory (Becker 1963; Thompson 2014); typification (Schutz 1967); and symbolic boundaries (Lamont and Molnár 2002; Lamont 1994, 2009).

This breadth of scholarly interest reflects the fundamental role of categorisation in human cognition and communication; as Kövecses argues, humans are "categorizing beings” who "categorize all objects and events we encounter in the environment. Categorization is necessary for action, and it is essential for survival” (2006: 17). In evolutionary terms, the ability to distinguish, say, logs from crocodiles has proved highly advantageous for survival. Similarly, the categorisation of clients is key to the functioning of street-level bureaucracies (as demonstrated thoroughly by Prottas 1979).

For heuristic purposes, it is useful to distinguish first between categorisation as process and as product (Blaxter 1978), and, second between informal and formal variants of the two, where formality is a question of whether products and processes are codified in legal or organisational policy. Together, this gives Table 1.

The product (hereafter referred to as a category) is "a cluster of things (acts, events, objects, traits) that are regarded as more similar to one another than to anything outside the cluster" (Zerubavel 1996: 442). It is usual to speak of both cognitive and communicative categories;

\footnotetext{
${ }^{19}$ More precisely, triage equates to a subtype of quantitative categorisation called commensuration (Espeland and Stevens 1998, 2008; see also article 4 of this dissertation).
} 
the former referring to how we group things in our minds and the latter to the conceptual 'boxes' of language (e.g. nouns such as 'patients', 'nurses' and 'priority setting') (Zerubavel 1996). Formal categories (cell 1A in Table 1) are key elements of street-level bureaucracies, determining client status and eligibility for the services in question (Prottas 1979). In triage, the main formal categories are the flow charts, discriminators and urgency levels of the MTS. However, formal should not necessarily be equated with consequential, as informal categories (cell 1B) may be just as important for how clients are treated. Indeed, as Dobransky (2009) showed in a study of formal and informal categorisation in a community mental health service, the latter often overrule the former. In the present context, the importance of informal categories is demonstrated especially in the third article exploring the informal category of 'GP patients' and its many sub-categories.

The process - referred to as categorisation - comprises everything that is done to assign someone or something to one or more categories (Blaxter 1978); in triage, this includes all the work that nurses do to determine a patient's placement within formal and informal categories of urgency. As we see in the present case, the triage nurses had to refer to guidelines that specify formal principles for sorting patients (cell 2A). ${ }^{20}$ However, street-level bureaucracies also afford workers some discretion in how they categorise clients, meaning that the process of categorisation is characterised by some degree of informality (cell 2B).

Table 1: Categories and categorisation: formal and informal variations.

\begin{tabular}{|l|l|l|}
\hline & A: Formal & B: Informal \\
\hline 1: Product ('category') & $\begin{array}{l}\text { Formal labels, e.g. triage } \\
\text { codes }\end{array}$ & $\begin{array}{l}\text { Informal labels, e.g. 'GP } \\
\text { patients' (see article 3) }\end{array}$ \\
\hline 2: Process ('categorisation') & $\begin{array}{l}\text { Official instructions for how } \\
\text { to categorise patients }\end{array}$ & $\begin{array}{l}\text { Unofficial criteria and } \\
\text { methods for categorising } \\
\text { patients }\end{array}$ \\
\hline
\end{tabular}

Whether formal or informal, categories and categorisation transform the world they purport to describe (Espeland and Stevens 1998: 314-8). This is often overlooked in everyday (and many scientific) understandings, which tend to view categories and categorisation as

\footnotetext{
${ }^{20}$ Of course, laws and regulations also specify formal principles for categorisation, but these are often so general that they give virtually no guidance for how to proceed (cf. Liodden 2017; Molander 2016).
} 
commonsensical, 'neutral' and 'natural' (Leder 1990; Mattingly 1998). In so doing, they neglect two crucial transformational aspects. First, categorisation is highly selective, emphasising some aspects while downplaying others. This selectivity is particularly striking — and systematic — in street-level bureaucracies. As Prottas explained, people are "far too complex to be effectively processed by a bureaucracy” (1979: 3). To accomplish bureaucratic categorisation, people must be simplified and standardised; they must be stripped of their biographies, feelings, inner worlds and other idiosyncrasies to fit the standardised form of bureaucratic categories. Consequently, rather than dealing with 'whole people', the "street-level bureaucracy is concerned with only a small part of the whole” (Prottas 1979: 3).

As well as being selective, categorisation is also perspectival; it involves not only selecting some neutral 'facts' over others, but also viewing those 'facts' through a particular lens or perspective (Zerubavel 1996). As an everyday example, the medical saying 'pick your speciality, pick your disease ${ }^{21}$ refers to how physicians from different specialties view the same set of symptoms and signs through the lens of their own specialism (and its adjacent conceptual apparatus). Similarly, Foucault's (2003) The Birth of the Clinic described the perspectival shift from a 'preclinical' mentality based on taxonomic classification to a 'clinical' mentality, “in which tissues, organs and diseases, once beyond the horizon of visibility, were laid bare” (Anspach 1987: 229). This illustrates the general point that all observations are theory-laden, shaped by the assumptions, conventions and interests of the interpreter (Hanson 1958).

As a practical activity, categorisation is always influenced by the surrounding circumstances (cf. Prottas 1979). Among other things, these include the jurisdictional boundaries in healthcare (Abbott 1988). For instance, categorisation work such as 'diagnosis' is regarded as the physician's exclusive domain, posing challenges for non-physicians when they are trying to assess the nature of a patient's medical complaint (cf. Allen and Hughes 2002; see also articles 1 and 2 of this dissertation). Other relevant conditions include the resource constraints typical of street-level bureaucracies as mentioned above. As Lipsky (1980: 83-5) argued, the combination of a large caseload and limited time prevents street-level bureaucrats from responding fully to client demands; instead, they must rely on routines and heuristics when processing clients. This means finding simplified ways of assessing clients, based on mental shortcuts and rules of thumb. While facilitating decision-making and making the job more

\footnotetext{
${ }^{21}$ While I cannot recollect a written source, I remember being told this by the key informant in my previous study of neurosurgeons (Johannessen 2013).
} 
manageable, this reliance on simplification can also have systematic consequences for clients, aiding some and harming others (Lipsky 1980: 84).

In adopting a bottom-up approach, this dissertation explores patient categorisation from the perspective of those doing the categorisation. As elaborated in Chapter 4, this partly involves putting oneself in the triage nurse's place to see how they assess patients and to understand the pressures and dilemmas they face in their everyday work. It also involves an attempt to get inside triage nurses' 'world of meanings' (Blumer 1969: 51) in order to untangle the cultural or knowledge-able aspects of their assessments. Following Van Maanen, “culture refers to the knowledge members ('natives') of a given group are thought to more or less share; knowledge of the sort that is said to inform, embed, shape, and account for the routine and not-so-routine activities of the members of the culture” (2011: 3). Building on Van Maanen’s definition, knowledge is understood in broad terms here, encompassing both explicit knowledge (i.e. that which can be easily articulated) and more tacit variations (i.e. skills, experiences and ideas that may be difficult or impossible to express) (Polanyi 1967; Spradley 1980: 5-9). Furthermore, the dissertation explores both professional (cf. Freidson 2001) and everyday knowledge (cf. Berger and Luckmann 1966; Schutz 1953). The latter is important because, as Hughes (1977: 130-1) argues, we risk giving too simple explanations of clinical work if we focus only on formal training and technical expertise. Instead, we must acknowledge how professional knowledge is often supplemented by or intertwined with the interpretive resources we acquire as members of a larger society. As demonstrated here, this broader view of knowledge helps in understanding how triage nurses make sense of clients and their complaints.

To sum up, this chapter locates the dissertation within the complementary perspectives of street-level bureaucracy and the sociology of standardisation, both of which advocate an open-minded, bottom-up understanding of how formal structures are enacted in micro-level practice. The practice in question is priority setting, which is conceptualised here as a form of categorisation, involving both the formal prescriptions and categories of the MTS and the informal procedures and interpretive resources of triage nurses' culture. This provides a basic framework for addressing the research questions of how and why triage nurses depart from the MTS, and, conversely, how the MTS influences their priority setting. 


\section{Chapter 4: Data and methods}

This chapter reviews the study data and methods. The data include the following:

- 47 fieldwork sessions at the primary EPCC mentioned above (where I observed and informally interviewed workers);

- follow-up interviews with seven nurses, two physicians and two managers;

- $\quad$ nine supplementary sessions at a second EPCC (8 sessions) and at an ED (1 session).

As the first of these is my primary source of data, the details of this fieldwork will be discussed most thoroughly in this chapter. To begin, I discuss my choice of an ethnographic approach before going on to describe the project's beginnings; how data were generated in the field; the supplementary sessions; some key ethical aspects; and how the data were analysed.

\section{Ethnography}

In line with a pluralist approach to methodology, the choice of methods must ultimately depend on one's research questions (Kalleberg et al. 2009). The questions here were how and why nurses depart from the MTS when prioritising patients in triage, and, conversely, how the MTS influences nurses’ priority setting. I consider ethnography the most appropriate approach to answering these questions.

Ethnography or fieldwork (I use the terms interchangeably) involves the first-hand study of people as they go about their everyday lives (Atkinson et al. 2001; Emerson et al. 2011). The method is typically traced back to anthropologists like Malinowski (1922), who argued the need for first-hand, direct experience of those under study, in contrast to 'armchair' anthropology based on second-hand accounts or ‘verandah' anthropology based on visits to missionary or diplomatic outposts (Van Maanen 2011: 14-17). In sociology, ethnography gained prominence through the first Chicago School, whose founding members treated the city of Chicago “as if it were a remote and exotic setting” (Van Maanen 2011: 18).

For present purposes, ethnography is the preferred methodology for a number of reasons. First, ethnography enables the researcher to observe first-hand what people do rather than relying purely on people's own verbal accounts of what they do (Jerolmack and Khan 2014). This is not to say that accounts are unimportant; on the contrary, as much of nurses' work cannot be observed directly (including the knowledge and reasoning underlying their assessments), one must rely on what they say in order to understand what they do. However, one crucial advantage of ethnography is that the researcher can situate the actor's accounts in 
the context of what they do from day to day, "when all the constraints of their ordinary social situation are operative” (Becker 1996: 62). This ‘triangulation' between accounts and actions is generally seen as one of ethnography's greatest advantages (Khan and Jerolmack 2013) and underpins the approach adopted here.

However, in arguing for the importance of first-hand experience, I do not mean to subscribe to the form of naïve realism advocated by Chicago school sociologists such as Robert E. Park, whose epistemology is characterised in the following terms by Van Maanen (2011):

\footnotetext{
Park was a former newspaper man who had great faith in the self-evident meanings of facts reported in straightforward ways. There was concern for “digging the data” so that "the real story" could be told. The representation of social reality was seen as technically unproblematic once the facts had been unearthed. [...] Little need was felt to do much more than gather and arrange the materials, for they would, in Park’s view, speak for themselves. (Van Maanen 2011: 18-19)
}

In contrast, I adopt an interpretivist stance (Geertz 1973; Schwandt 1994), emphasising that fieldwork is always selective, perspectival and dependent on the ethnographer's hermeneutic capabilities. For one, ethnography is always selective in terms of the times, places and actors one chooses to study. Furthermore, just like the people under study, ethnographers inevitably perceive the world through a particular cultural lens, foregrounding some things at the expense of others, according to a range of tacit and explicit interests (Zerubavel 1997: 37, 5052). A related point is that ethnographers, through their participation, are likely to alter (however slightly) the situations under study (cf. Becker 1996: 61-2).

That said, I do not take interpretivism to suggest that there are no advantages of being present when people are actually doing the things that are of interest. As I see it, the point is rather that we should be careful not to treat observable events as self-evident 'facts' (Atkinson and Coffey 2003), and that we must be reflexive in generating and interpreting data (cf. Emerson et al. 2011). Granted these reservations, ethnography is widely acknowledged to be the preferred method for studying what people do in their 'natural setting' (Jerolmack and Khan 2014).

In the same way, it can be argued that ethnography is the preferred methodology in seeking to explain why triage nurses depart from the MTS (and, more generally, why they do the things they do). Based on the interpretivist principle of Verstehen, explanation requires the researcher to locate people’s actions “in an intelligible and more inclusive context of meaning” (Weber 1978: 8) by considering their "situated intentions, beliefs, and 
opportunities” (Turco and Zuckerman 2017: 1273). To revisit a related point in Chapter 3, the interactionist Blumer argued that to understand why actors behave the way they do, we need to get inside their 'world of meanings' (1969: 51). In one particularly illuminating passage, he criticised the then dominant behaviourist programme and explained how the sociologist should instead proceed:

Since action is forged by the actor out of what he perceives, interprets, and judges, one would have to see the operating situation as the actor sees it, perceive objects as the actor perceives them, ascertain their meaning in terms of the meaning they have for the actor, and follow the actor's line of conduct as the actor organizes it - in short, one would have to take the role of the actor and see his world from his standpoint. (Blumer 1969: 73-4)

While other methods may also achieve this aim (cf. Lamont and Swidler 2014), ethnography offers an especially useful route into the actors’ world of meanings by facilitating 'immersion’ in the social life of that group. According to Emerson, Fretz and Shaw (2011: 3), immersion means partaking in people's lives to learn about their regular daily activities, what they find meaningful and how they perceive and deal with the challenges, constraints and pressures of their everyday life. Immersion is in part facilitated by long-term participation and the concurrent richness of data available to the fieldworker. Through first-hand participation in a social milieu for an extended period, the ethnographer can sample people’s sayings and doings in a range of settings and situations, comparing these various data points to make strong inferences about people's reasons for behaving as they do (Becker 1996; Jerolmack and Khan 2014). In the present case, that included observing how nurses seemed to treat some 'types' of patients differently, and then matching those patterns to evaluative talk about these 'types' in various settings (see in particular article 3). While these are clearly inferences (cf. Reed 2008), the point is that the richness of ethnographic data provide good grounds for drawing strong explanatory inferences (Jerolmack and Khan 2014).

In sum, I believe ethnography offers a fruitful means of understanding the hows and whys of triage nurses' practice. While the answers it provides will always be partial, this should be no ground for resignation; instead, I concur with the claim that the epistemological challenge "is to open up the ethnography for readers to assess the validity of the claims being made” (Neyland 2008: 49). That, indeed, is the aim of the remaining sections of this chapter.

\section{Beginnings}

In planning this chapter, it was tempting to write as if every choice was meticulously planned prior to entering the field (and indeed, the first draft did exactly that). However, qualitative 
research (and quantitative, for that matter) is rarely a linear, pre-planned process. The Norwegian anthropologist Cato Wadel (1991: 129) famously compared it to a 'round dance', as it involves constant alternation between data, methods and theory.

The dissertation did not start out as a study of standardisation and discretion in triage. My initial idea was simply to conduct an exploratory ethnography of how staff interpret and prioritise patients in some or other emergency service. I originally considered EDs; as these are key access points in most healthcare systems (cf. Vassy 2014) and typically receive more patients than can be treated simultaneously, they face the constant challenge of sorting urgent from non-urgent. As most EDs are also walk-in institutions, they deal with a diverse range of problems and may face serious interpretive difficulties. For these reasons, I identified the ED as an ideal setting in which to study the interpretation and prioritisation of patients.

However, I quickly learned that Norwegian EDs differ from most international equivalents in that they do not allow patients to walk in at their own discretion. To study priority setting under the circumstances outlined above, I was advised to study EPCCs instead, as these most closely resemble other countries’ EDs. As mentioned earlier, EPCCs are heterogeneous institutions, ranging from a single physician on call to large-scale organisations employing hundreds of workers (Hansen and Hunskår 2016). For my purposes, the latter type seemed ideal. Fortunately, my main supervisor, Dag Album, knew a physician in such an EPCC, and a meeting was arranged with the clinic's management. The meeting was scheduled for midDecember 2014, and as I was knee-deep in papers to grade before Christmas, I went into the meeting less prepared than I should ideally have been. I felt hesitant when explaining my project to the managers, and I sensed significant scepticism. As I left, I felt sure I would have to find another EPCC after Christmas. To my great surprise, however, I received an email in early January 2015, inviting me to make arrangements for my fieldwork. But there was a catch: I was initially granted permission to observe only nurses and auxiliary nurses. As I had originally planned to include physicians in my sample, this limited the scope of my research. However, fearing they might withdraw their offer, I did not protest.

\section{The clinic}

The EPCC in question was a large and complex clinic, receiving more than 50,000 patients yearly $^{22}$ and employing approximately 100 nurses, 30 doctors, and 15 auxiliary nurses ${ }^{23}$, as

\footnotetext{
${ }^{22}$ To avoid identification, this number is approximate.

${ }^{23}$ For convenience, this term lumps together two distinct occupations: health secretaries ('helsesekretærer') and enrolled nurses ('helsefagarbeidere', better known as 'hjelpepleiere').
} 
well as non-clinical workers including security guards and cleaning staff. The clinic was open 24/7, all year round, and patients could walk in at their own discretion (which frustrated many of the nurses, as elaborated in article 3). Located in the middle of one of Norway's largest cities, it had its fair share of tourists, immigrant workers and 'social cases' (Friedman 2009). Clients were representative of all the city's population groups, although not in equal proportion; given the many private providers in the city, the city's more affluent citizens were somewhat underrepresented.

In terms of urgency, the clinic's patients were distributed as follows: $0.5 \%$ were assigned a 'red’ triage code (the most urgent); 21\% were ‘orange'; 51\% were 'yellow'; 27\% were 'green'; and $0.1 \%$ were 'blue'. According to an internal report, the percentage of orange and yellow patients was higher than at most other Norwegian EPCCs. Coupled with the fact that this is one of Norway's largest primary care clinics, many staff saw it as halfway between a primary care EPCC and a secondary care ED.

Although the EPCC had experienced a steady increase in visitors in recent decades, financing seemed to lag behind. For instance, a restructuring of the reimbursement system meant that the EPCC experienced de facto budget cuts just a few months before I commenced fieldwork. That said, the clinic's main manager emphasised that the question of financing is complex, as the clinic receives funding from several different sources, each with its own system (having little expertise in this area, I am in no position to challenge his claim).

The clinic was located in an old, run-down building of several storeys, each with its own confusing architecture. Patient-centred work happened mainly on the first floor, where workers distinguished (heuristically) between the clinic's 'frontline' (reception area, waiting area and two triage booths) and 'inside' (another waiting area, a work station and a series of examination rooms). At the frontline, patients were greeted by the receptionists, who were either auxiliary or newly hired nurses. Their job was to record patients' administrative details and to prioritise the most urgent patients for the next checkpoint: triage. This was performed in a dedicated space next to the frontline waiting area, where triage nurses sat in semi-closed booths and called patients in. The triage nurses' role was to determine how long patients could wait before seeing a doctor. A triage assessment typically lasted 4-8 minutes, during which the nurse would record a brief medical history, ask about relevant previous diseases and medications, record vital parameters (including pulse, respiratory rate and temperature), and sometimes perform examinations (such as simple neurological assessments). At the end, the nurse would settle on one of the five MTS urgency levels before sending the patient 
'inside' to the other waiting area. While waiting, patients were often called in by the nurses for various tests (e.g. ECG, blood tests). Finally, a physician would examine the patient and decide on a diagnosis and plan for further action. All of this work was supervised by a coordinating nurse and physician, who shared a work station with physicians and nurses working 'inside' the clinic.

As this overview suggests, most patient-centred work was carried out before the patient met with the physician. After realising this, I was less uneasy with 'only' having access to nurses and auxiliary nurses; indeed, I started to doubt the need to observe physicians at all. While I did later negotiate permission to shadow physicians, it was demanding enough in the first place to gain an adequate understanding of the many non-physicians, including receptionists, lab workers, triage nurses, coordinating nurses and other 'inside' roles, each with slightly different responsibilities. As I elaborate in the next section, I began by shadowing all of these personnel to learn more about their work and to see the organisation from their differing perspectives; it was only after extended observation and subsequent analytical work that I decided the study would be about standardisation and discretion in triage.

\section{In the field}

Of the 47 fieldwork sessions at the primary EPCC, most were conducted between April and September, at a rate of 2-3 sessions per week. October was spent completing supplementary observations at another EPCC before I returned to the primary EPCC in November and December.

In all of these fieldwork sessions, my main strategy was to 'shadow' (Czarniawska 2014) EPCC staff by tagging along with an employee during their shift. This enabled me to see the shift more or less as they did while also allowing me to 'stick around' at times when nothing seemed to be happening. To avoid undue confusion for staff and patients, management required me to dress in the EPCC uniform, wearing a large badge on my chest that read 'LARS—RESEARCHER' in big block letters. The uniform had some obvious advantages, giving me unquestioned access to most areas of the EPCC and indicating to staff that I was, in some sense, 'one of them'. While there was occasional confusion about my role in the field, I could usually resolve this by pointing to my badge and briefly explaining my role as a researcher. The combination of uniform and badge seemed a viable compromise in the interests of access, transparency and the daily order of the clinic. 
The 47 sessions totalled approximately 300 hours in the field (see Table 2), representing an average session duration of 6.5 hours. I aimed primarily to shadow whole shifts (lasting 7.5-9 hours), as this seemed the best way of developing rapport with staff and increasing the breadth of the observed interactions. To maintain focus, I took regular note-writing breaks that divided the longer sessions into several shorter intervals (more on this later).

Table 2: Overview of fieldwork sessions in the primary EPCC.

\begin{tabular}{|c|c|c|c|c|c|}
\hline Type & Shift & & & Total sessions & Total hrs. \\
\hline & Morning & Evening & Night & & \\
\hline Triage (reception) & 5 & 5 & 3 & 13 & 74 \\
\hline Triage (ambulance) & - & 1 & 2 & 3 & 24 \\
\hline Triage (telephone) & 1 & 3 & - & 4 & 31 \\
\hline Triage courses & - & - & - & 2 & 15 \\
\hline Receptionists & 2 & 1 & 3 & 6 & 38 \\
\hline Supervising nurses & 2 & 2 & 1 & 5 & 27 \\
\hline Physicians $^{24}$ & 6 & 2 & - & 8 & 53 \\
\hline Misc. $^{25}$ & - & - & - & 6 & 40 \\
\hline Total & 16 & 14 & 9 & 47 & 302 \\
\hline
\end{tabular}

Almost half of my time in the field (about 145 hours) related to triage nursing in one form or another. Triage was performed at three different sites in the EPCC: in the reception area, in the ambulance area and in the clinic's call centre. At all three sites, nurses performed assessments based on MTS guidelines. Although I covered all three, I have confined the present account to instances of face-to-face triage in the reception and ambulance areas. Telephone triage was excluded mainly because it has already been quite extensively studied (see the review in article 1), and because it proved more difficult to obtain informed consent from patients over the phone (mainly because nurses found it interactively challenging to

\footnotetext{
${ }^{24}$ After three months without complications, I decided to ask physician management whether I could shadow physicians. They agreed, as long as I made individual arrangements with the physicians I wanted to shadow. Although I did not ultimately refer explicitly to these data in any of the articles, shadowing physicians alerted me to the similarities between triage nurses' assessments and physicians' consultations (which was of particular relevance to article 2) and also helped me see how physicians' work was influenced by the decision-making of triage nurses.

${ }^{25}$ This includes three sessions shadowing personnel performing various roles 'inside' the clinic; one session following patients throughout the EPCC; one attending a bipartite course about the unrelated topics 'children' and 'intoxication'; and one following a lecture about EPCC medicine delivered by a clinic physician to finalyear medical students. (I included the latter when reporting the number of physician observations in article 2, for a total of nine observations.)
} 
explain my 'eavesdropping' to callers). In total, I observed 342 face-to-face assessments ${ }^{26}$ by 2 male and 14 female nurses aged between 25 and 35 who had worked at this EPCC for 3.5 years on average (range 1-7 years).

Given the dissertation's focus, I might arguably have spent more time shadowing triage nurses. However, as I entered the field with exploratory intent, I was concerned not to narrow my focus prematurely. In retrospect, I can also say that it would have been counter-productive to confine my observations solely to triage, as nurses rotated between this and other roles in the clinic. Tracking them in all these roles allowed me to observe how their triage assessments were influenced by other things they did, which turned out to be relevant for all the articles of this dissertation (especially article 2 on workplace learning). In addition, by studying all clinical roles, I gained a better understanding of the clinic as a whole and of how triage nurses' decision-making was linked to the actions of others, such as receptionists, supervisors and physicians.

I planned which roles, shifts and people I would shadow on a week-to-week basis. However, I did not have full freedom in this regard, as I could only specify what role, day and shift I wanted to study, and the clinic's shift supervisor would then pair me with a particular member of staff. Having interacted with most EPCC workers at the time of the study, I have little reason to believe there was any systematic bias in this selection, with one exception: management was reluctant to let me shadow nurses who were being trained by other nurses. Although this precluded direct observation of how new triage nurses were trained, I tried to cover this topic in formal and informal interviews. Additionally, on two occasions, I was lucky enough to witness training sessions in the adjoining triage booth, as the two booths in the frontline were connected by an 'escape route' that allowed me to see and hear much of what went on 'next door'. So, while it would have been preferable to observe some training sessions directly, these 'indirect' observations and the interviews went some way toward rectifying this limitation.

In total, I shadowed 41 people at the primary EPCC: 27 nurses (7 male, 20 female), 8 physicians (4 male, 4 female) and 6 auxiliary nurses ( 1 male, 5 female). Most of the nurses were aged 25-35 and held a bachelor's degree in nursing (as is required for the protected title of 'nurse' in Norway). ${ }^{27}$ As this was a popular urban clinic, the EPCC was able to recruit

\footnotetext{
26 The number was incorrectly reported as 349 in article 1.

${ }^{27}$ Most physicians were 30-35 and on their way to becoming specialists in general medicine, whereas most of the auxiliary nurses were above 50 years and had worked in the EPCC for five years or more.
} 
candidates with good diplomas. However, it did not attract the most experienced nurses, as one of the clinic's senior physicians explained:

It's generally difficult to recruit experienced nurses, as we don't have a lot of full-time positions to offer. And it's hard work, you know, they're working a tripartite rotation, and you've seen how much work it can be during night shifts and the like. The older nurses don't want that, so this is a place for the young and driven, really.

In addition, the clinic generally attracted nurses who had a higher than usual level of interest in emergency medicine and its (stereotypically masculine) idealisation of action, life-saving and drama (cf. Hillman 2007). This was perhaps one reason why the clinic had a relatively large (though still small) share of men: approximately 16\%, as compared to about $9 \%$ in the Norwegian nursing population as whole (SSB n.d.).

\section{Observations in and of triage}

As the dissertation focuses on triage, my observations of this role warrant particular mention. Most of the 342 assessments were observed in the reception area $^{28}$ while sitting next to a nurse in one of the two adjoining triage booths. Each booth was approximately $2.5 \times 2.5$ meters, with glass windows to enable nurses to keep an eye on those waiting. In the middle was a desk with a computer and medical equipment, with two chairs for patients and caregivers in front of the desk, and one chair for the triage nurse behind the desk.

When observing reception area assessments, I positioned myself a little to the side of the triage nurse, enabling me to see both the computer screen and much of the non-verbal interaction between nurse and patient. During each assessment, I noted the nurse's choice of flow chart and discriminator, as well as basic, non-identifying information about the patient (such as visible gender, ethnicity, age and clothing) and an estimate of duration. Beyond this, I also tried to capture as much as possible of what went on in the assessment, including the verbal exchange between nurse and patient; significant aspects of their non-verbal interaction; any tests and examinations performed by the nurse; and an anonymised version of the nurse's documentation. (As discussed later, capturing all this information proved challenging for notetaking.)

\footnotetext{
${ }^{28}$ Triage in the ambulance area differed from reception area triage in a few respects, including that it was performed standing rather than sitting; that the patients usually presented with more critical conditions; and that ambulance personnel were present at the beginning of the assessments (before leaving after giving a brief report to the nurse). However, as none of these differences have any substantial bearing on my conclusions, I refrain from going into greater detail.
} 
As my aim was to get inside nurses' world of meanings (Blumer 1969), I devoted significant time and effort to trying to understand the situated logic of triage nurses' assessments. After the patient had left the triage booth, I usually asked the nurse to comment on their choice of flow chart and discriminator in the MTS, and whether they had any other thoughts about that particular assessment. On slower days, we regularly engaged in longer conversations about each assessment, which allowed nurses to offer more elaborate accounts of their actions while the assessment was still fresh in their mind.

To gain a deeper grasp of these assessments, I also spent significant time familiarising myself with the MTS. I participated in courses, read the MTS book and studied the flow charts. While observing triage nurses, I occasionally engaged in 'mock' private assessments of patients, using my own copy of the MTS manual. This sensitised me to the occasional difficulties of reducing patients to the guidelines' categories and generated many issues for post-assessment discussion.

Finally, I also learned a lot simply by being with the nurses in triage. According to Goffman, ethnography involves “subjecting yourself, your own body and your own personality, and your own social situation, to the set of contingencies that play upon a set of individuals, so that you can physically and ecologically penetrate their circle of response to their social situation” (Goffman 1989: 125). Among other things, this allowed me to experience some of the fatigue and frustration associated with rapidly assessing patient after patient in assemblyline fashion. Along with the data this provided, it also helped me develop rapport with the nurses, sharing our frustrations and engaging in tired banter between assessments.

\section{Informal interviews}

Interviews are an integral aspect of most ethnographies, and as already indicated, I spent a lot of time informally interviewing (cf. Spradley 1980: 123-4)—or, in everyday terms, conversing with — the staff members I shadowed. As a clinically illiterate sociologist, these informal interviews were crucial to understanding much of what I observed, both during triage and elsewhere.

The informal interviews also helped me see how the nurses generally perceived their environment. This included their informal, value-laden notions about patients, which I explore in detail in articles 3 and 4. Participating in the field proved especially fruitful in eliciting these views, as nurses regularly encountered patients they found irritating, fascinating or confusing. Accordingly, I rarely had to inquire directly about such topics (indeed, on the few 
occasions when I did, the reaction tended to be defensive and uneasy); instead, I usually waited for these topics to arise 'naturally', in response to the contingencies of the field.

Notwithstanding the centrality of these informal interviews, it must also be said that they presented some interactional challenges. As staff generally seemed potentially busy, it was often difficult to judge whether it was appropriate to ask questions. For fear of appearing rude and distracting, I initially opted for Rock’s strategy: “remain in the margins at first, available, just about visible, but not too demanding” (2001: 34). While this approach offered some advantages (e.g. informants occasionally seemed to forget my presence), it also meant that many questions were left unasked or unanswered. After a few sessions, I decided I could simply ask nurses about their preferences, and most of them assured me they had no problem answering brief questions and explaining their actions after the patient had left. Reassured, I gradually began to ask more questions, and far from finding this bothersome, the nurses often seemed eager to explain the logic, challenges and dilemmas of their everyday working life. Some settings were particularly conducive to conversation. For instance, when shadowing someone at the work station shared by nurses and physicians, I had plenty of opportunities for brief, informal conversations with the many workers occupying this space. As I shadowed nurses throughout most of their shift, I typically joined them for their lunch break too, where we could engage in relatively extensive discussions of their work. Whenever the nurses ate lunch together (as they often did), these discussions became focus group-like, often relating to topics that nagged or fascinated them and so providing valuable data. In these situations, I would mostly sit and listen to their talk, only occasionally asking brief questions of interest. ${ }^{29}$

\section{Field notes}

The writing of field notes is a central but challenging aspect of fieldwork, both in- and outside of the field. Concerning the former, Emerson, Fretz and Shaw has noted, "fieldworkers must constantly rely upon interactional skills and tact to judge whether or not taking jottings in the moment is appropriate” (2011: 38). Wary of this, I tried to vary my notetaking with different situations and audiences. To avoid disturbing staffs’ interactional dynamic, I tried to limit my notetaking in backstage settings, and I was especially careful whenever they discussed valueladen topics, such as patients they liked or disliked. In such cases, I typically refrained from taking notes at all, instead relying on 'mental' notes that I could expand on later.

\footnotetext{
${ }^{29}$ Listening often brings great payoffs; as Whyte remarked, “As I sat and listened, I learned the answers to questions that I would not even have had the sense to ask” (1993: 303).
} 
In front of patients, on the other hand, staff often seemed to forget my presence, and so I was relatively liberal in my notetaking (while trying, of course, not to miss important aspects of the interactions in front of $\mathrm{me}^{30}$ ). As previously mentioned, I tried to capture as much as possible of what went on in the triage assessments. This proved exceedingly difficult, especially in the beginning, when I took notes by hand. After six sessions, I decided to try taking notes on a 13-inch laptop instead. I was pessimistic to begin with, as I expected patients would react or question my actions, but no one seemed to notice the laptop. In retrospect, I can think of several explanations for this lack of concern-for instance, the laptop was quite small and discreetly placed in my lap; the nurses themselves had computers; patients may have considered the setup 'natural' once I had been introduced as a 'researcher'; and finally, there was the somewhat 'ad hoc' feel of the EPCC, which was quite run down, constantly noisy and almost always frequented by construction workers who performed seemingly never-ending repairs. Whatever the reasons, the laptop allowed me to take notes significantly faster, and touch typing enabled me to keep my eyes on what was happening in front of me. In short, typing proved to be a good compromise between writing notes by hand and using an audio or video recorder (which management had, in any case, prohibited).

When shadowing workers in less deskbound roles than triage, I used a notepad to jot down keywords, quotes and summaries of the action in front of me. It was not uncommon for staff to carry notepads, so I did not particularly stand out (unlike, for instance, when observing nightlife or criminal gangs). However, here as elsewhere, I did take care to explain why I was writing extensive notes, emphasising the importance of full and accurate accounts. This was no lie, as the jottings subsequently proved invaluable when writing more extensive notes.

About every second hour, I retreated to a secluded break room to elaborate on my notes for anywhere between 15 and 45 minutes. Using my laptop, I was able to sketch quite detailed notes to be developed later. Given the average length of my sessions, these breaks were crucial for writing extensive and accurate notes, and for providing an opportunity to reflect on what I should focus on in the rest of the session. The breaks also allowed me to recharge for another concentrated session, as well as giving the staff member I was shadowing some breathing space and limiting any tension or discomfort they may have felt.

\footnotetext{
${ }^{30}$ As argued by Emerson, Fretz and Shaw, “A field researcher will inevitably miss fleeting expressions, subtle movements, and even key content in interactions if his nose is in his notepad” (2011: 39).
} 
Given my fairly extensive notetaking, staff sometimes remarked that I wrote a lot, and they occasionally asked what and why I was writing. In such cases, I typically responded by explaining the need for accuracy and detail, adding jokingly that this is the fieldworker's burden. Most expressed understanding; some even pitied me for having to do all this writing. While their reactions revealed some awareness and potential unease about being observed, they seemed to take my note-taking more for granted over time. Indeed, by being open about my writing and my reasons for doing so, I believe I was able to establish a 'note-taker role' (Emerson et al. 2011: 37), in which my writing became part of what people expected.

I tried to write full notes as soon as possible after each fieldwork session. When shadowing morning shifts, I tried to write up the notes on the same day; for evening or night shifts, I began working on my notes first thing next morning. In the latter case, I went over my notebook and filled in details before going to bed, making it easier to write the next day. I aimed to write as exhaustively as possible about anything that seemed to relate to how staff interpret and prioritise patients (and about everything else I suspected might be of relevance later). While my notes cannot be regarded as 'objective' recordings of what went on in the field (Wolcott 1994: 13), I tried to write as descriptively as I could, to 'show, don’t tell' and to use low-inference descriptors (i.e. words involving as few interpretive 'leaps' as possible (cf. Seale 1999: 148)). Most of my notes were written chronologically and in the present tense, as I found this helped to jog my memory and to develop more detailed descriptions. While writing, I supplemented the descriptive notes with theoretical and methodological reflections; these were bracketed off from the rest of the text to keep the descriptive accounts as descriptive as possible (Emerson et al. 2011: 80).

On average, I spent up to twice as long writing notes as following people in the field. Although rewarding, I often detested the writing process, as I found it extremely tedious and energy-consuming to recount the minutiae of my sessions. Indeed, this extensive note taking seems the most significant drawback in shadowing workers for so many hours at once. As well as being mentally and emotionally draining, it also took a bodily toll; while writing, I almost developed tendinitis, a problem rarely mentioned in ethnographic handbooks. Luckily, I was able to complete the fieldwork without chronic injury to my arms, but this was an ongoing concern throughout.

\section{Field relations}

What fieldworkers learn about the world they study depends in part on their role in the field and how they are perceived by informants (cf. Ugelvik 2014; Venkatesh 2002; Wadel 1973); 
hence, this section reflects on how I was perceived by nurses, and how I worked towards a role that aligned with the aims of my study. In a general sense, I sought to develop a role that would allow me to observe and inquire about nurses’ practices without interfering unduly in the everyday dynamics of the field, especially in situations involving patients. At the outset, this role seemed hard to achieve. ${ }^{31}$ Whenever I met new members of staff, they treated me initially in a somewhat formal way; while curious and welcoming, they also seemed hesitant. Most knew, or soon learned, that I was there as a researcher, but they did not know what kind of researcher I was, or what I was there to learn. Their jokes and remarks suggested a slight fear that I was out to 'expose' them, and many seemed to treat me with a degree of caution.

This situation was not ideal for learning about daily dealings with patients. However, I could not simply decide to change roles; this had to be interactively accomplished (Garfinkel 1967). I therefore invested significant time and effort in gaining staff trust; for instance, I tried to arrive early before each fieldwork session to allow time to introduce myself and my project to each newly encountered member of staff. When shadowing someone, I assured them that they would remain anonymous; that the project was exploratory; that I wanted to see the EPCC from their point of view; and that I, as a sociologist, was neither interested in evaluating their work nor competent to do so. As mentioned above, I also made sure to explain my need to take notes; and I tried responding with curiosity, interest and support to whatever they did or said rather than being sceptical or judgmental. (As a generally non-confrontational person, this was not difficult.)

After a few weeks, I had met almost every member of the nursing staff, and most knew who I was and why I was there. It is difficult to pinpoint exactly how nurses had come to see me, but I got the impression that most interpreted me, roughly, as a somewhat naïve and curious visitor-one who asked a lot of questions and wrote a lot of notes, and who wanted to see what the EPCC was like from a staff perspective. Although they probably did not grasp exactly what was of interest to me (in part because I was also unsure), they seemed to accept that I posed no immediate threat to them or to their work.

\footnotetext{
${ }^{31}$ Strictly speaking, such a role is unattainable. However, given my research questions, I found it worthwhile to minimise my presence as far as possible. In this respect, I concur with Geertz' remark on objectivity: "I have never been impressed by the argument that, as complete objectivity is impossible in these matters (as, of course, it is), one might as well let one's sentiments run loose. As Robert Solow has remarked, that is like saying that as a perfectly aseptic environment is impossible, one might as well conduct surgery in a sewer.” (1973: 30).
} 
Through relatively frequent visits to the field, I also attained a sort of 'insider' role in the clinic, at least among the staff with whom I interacted most. As cited in article 3, Nurse Alice stated this quite explicitly in her interview:

Now that you've been working with us for so long, [...] you've seen it yourself; you know what we're talking about, and you don't respond by raising your eyebrows thinking ‘Oh my gosh! Are you a nurse?'

As Alice put it, I had seen things for myself and had responded without raising my eyebrows or questioning their professionalism. As indicated, I believe this made the nurses more open about the informal and value-laden aspects of their work, which afforded me easier access to information about their various departures from the guidelines.

Some social characteristics seem likely to have facilitated nurses' trust and cooperation. For instance, my status as a sociologist and my lack of healthcare experience seemed to allow me to be more unsanctionably naïve than a healthcare worker could have been. At 26, I was also a few years younger than most of the nurses and physicians I shadowed. Youth is often disarming; like Album, I felt like "it was reasonable for a young person to wander around, seemingly oblivious, wondering what people were doing.” (1996: 244; author's translation). Additionally, my appearance is fairly anonymous and non-threatening, ${ }^{32}$ and I have a slightly introverted and whimsical personality, especially in front of strangers. There were several indications that this was indeed how informants saw me, the most blatant being a curious coincidence. At a party, a colleague met someone who turned out to be my one of my informants, who went on to describe me as 'whimsical', 'kind', 'cute' and 'unthreatening' all adjectives I consider favourable for eliciting trust and cooperation.

However, I must also acknowledge some limitations in this regard. My insider status was only partial, and it seems likely that nurses were less willing to share certain kinds of information with me. For instance, as I interacted with workers from different occupational groups (nurses, physicians, auxiliary nurses and, to a lesser extent, management), they were probably reluctant to voice inter-group conflicts (although occasional remarks were made). For similar reasons, I find it unlikely that they would have shared damaging information about themselves or their colleagues. Additionally, as previously indicated, my presence probably made nurses more aware of their actions in front of patients (although to varying degrees and perhaps to a lesser extent than if shadowed by a clinically adept colleague). Such 'reactive

\footnotetext{
32 To be more specific, it is not uncommon for both friends - and, annoyingly, complete strangers - to remark that I look like Edward Snowden, the American computer professional and whistleblower.
} 
effects’ are inevitable in ethnographic research (Becker 1996), and I do not believe my presence significantly altered the dynamic between nurses and patients. However, it seems important to emphasise the inescapable partiality of my account, and to acknowledge that my presence did not go unnoticed by actors in the field.

\section{Formal interviews}

In addition to the many informal interviews, I formally interviewed seven nurses, two physicians and two mid-level managers towards the end of the fieldwork. These interviews had varying goals. The interviews with management were mainly to gather factual information and to explore their views on formal guidelines in the EPCC. In contrast, the interviews with physicians and nurses sought to elaborate certain themes and test some tentative conclusions, and to check whether anything of significance had been overlooked. The low number of physicians reflects my end-of-fieldwork insight that this was primarily a study of nurses rather than physicians. Accordingly, those two interviews were largely a ritual 'just in case’ exercise, and while they expressed some interesting views on triage nurses’ work, these did not contribute significantly to the dissertation's conclusions.

As the interviews with nurses clearly played a more central role, these warrant further comment. Because their purpose was to elaborate and test tentative conclusions, I had decided to interview nurses with whom I had already developed some rapport, so allowing for freer flow of information (Spradley 1979: 44). The sample depended to some extent on chance, as I recruited interviewees from the nurses I encountered in the final month of fieldwork. The interviews were conducted in one of the clinic’s many private areas and lasted about 80 minutes on average (ranging from 40 minutes to 3 hours). My interview guide comprised seven batteries of questions: one related to the nurse's background information; three on the roles of receptionist, triage nurse and supervising nurse; two eliciting views on patient eligibility and on turning non-eligible patients away; and a final one focusing on patients they thought should be assigned higher or lower priority. The questions were open-ended, and the guide was used mainly for reference; as far as possible, I tried to follow up on the nurses’ answers without intruding on or interrupting their accounts (Weiss 1994: 78-9). As in the informal interviews, my interviewing style was mainly empathetic and understanding (Spradley 1979: 46).

In general, I found that the nurses' accounts were largely consistent with observations and conversations in the field. Moreover, as their answers mostly supported my tentative conclusions, I was reassured that I had not overlooked or misunderstood anything significant. 
The interviews also added some valuable data by allowing staff to answer more thoroughly than while on duty, providing additional data points for comparison with others. Beyond this, however, the interviews added few novel insights about nurses’ priority setting, and while undoubtedly useful, the interviews remained secondary to the fieldwork itself.

\section{Supplementary observations}

As my project was exploratory and I wanted to develop an in-depth understanding of the EPCC in question, I chose to complete most of my observations in the primary EPCC. However, for analytical contrast I also conducted nine supplementary fieldwork sessions in two other emergency services: eight at a smaller EPCC and one at an ED.

The eight sessions in the smaller EPCC amounted to a total of 50 hours and were conducted in October 2015. ${ }^{33}$ This clinic was located in the same city as the primary EPCC, further from the city centre but closer to a hospital. It had restricted opening hours and received about half as many patients as the primary EPCC. Patients were assessed at two locations: the reception and ambulance areas. I spent most of my time in the reception area, where auxiliary nurses were principally responsible for performing urgency assessments. They categorised patients according to three levels of urgency and were not required to use a standardised triage system (such as the MTS). For that reason, observing their assessments sensitised me to the role of MTS at the primary EPCC. In the ambulance area, nurses were in charge of urgency assessments, and they were instructed to use the MTS. While I spent only a few hours observing the ambulance area (mainly because so few ambulances arrived while I was there), these observations allowed me to study the use of MTS in a different setting. While I have not explicitly reported any of these data in the articles, my time in this smaller clinic provided an analytically sensitising contrast to what I learned in the primary EPCC.

Arrangements with the supplementary ED were made with the help of a colleague in the summer of 2016. This large-scale, hospital-based department employed triage nurses to sort incoming patients. The nurses were required to use MTS, and my day in the field was spent observing their triage assessments. These observations aligned well with what I had learned in the primary EPCC.

\footnotetext{
${ }^{33}$ Access was negotiated in a brief meeting with its two head managers. Because I only requested eight fieldwork sessions and had completed fieldwork in the primary EPCC without any complications, they seemed happy to grant me access.
} 
Had I known from the outset that the dissertation would ultimately focus on standardisation and discretion in triage, it would have been interesting to conduct further in-depth studies of other organisations to cover different types of actors, settings and triage systems. However, as my project was exploratory and sought to develop a comprehensive understanding of the primary EPCC, this extension would have proved challenging. In any event, there are some advantages in focusing on one key site, as this facilitates the development of rapport and provides a richer understanding of local context (cf. Geertz 1973). Moreover, the primary EPCC is well suited for exploring the relationship between standardisation and discretion in triage, as it, among other things, uses a widespread triage system and dedicates significant resources to ensure that nurses know and follow this system. So, while the sample is not without its limitations (to which I return in the Discussion section), I believe it adequately addresses the dissertation's research questions.

\section{Ethical considerations}

\section{Formal approval}

The Norwegian Social Scientific Data Services approved both the fieldwork and the formal interviews on March 172015 (see Appendix 3). The project was also reported to the Regional Committees for Medical and Health Research Ethics, who determined that the project was not notifiable because I had no intention of collecting personal information about patients. I signed non-disclosure agreements with the organisations studied.

\section{Informed consent}

Informed consent was secured both orally and in writing. Prior to fieldwork, staff received an email about the project. I also made oral presentations at several morning meetings and sought to introduce myself and the project to every member of staff I encountered. When shadowing staff, I briefly explained the study and what their participation would entail, also handing them an information letter that included my contact details and a more thorough explanation (see Appendix 4).

In addition, I sought the informed consent of the patients I encountered in non-public settings. However, as management required staff to ask on my behalf, I was dependent on their presence of mind. This resulted in some dilemmas in triage, where nurses occasionally forgot to introduce me. As this happened only when patients presented with non-sensitive complaints (e.g. abdominal pains or sore throats), I considered it wise to let the nurse get on with the assessment, relying on my badge to convey my status to the patient (giving the nurse a gentle 
reminder after the patient had left the triage booth). While arguably a breach of formal guidelines, I believe it would have done more harm to interrupt the nurse to state my presence and purpose. As Bosk (2008) argues,

An overly scrupulous approach to informed consent would create disruptions of social life, would be intrusive, would heighten self-consciousness of actors to a high degree, and would be so socially bizarre that it would make fieldwork impossible to complete. (Bosk 2008: 155)

\section{Confidentiality}

Ensuring informants’ confidentiality means not publishing data that might expose their identity. While external confidentiality means protecting informants from being recognised by someone outside the field, internal confidentiality means preventing informants from recognising each other (Tolich 2004). To comply with both considerations, I used pseudonyms for both staff and their workplace and ensured that informants were anonymised in the field notes. Because I shadowed such a large number of people, it would be close to impossible for either insiders or outsiders to make inferences about the individuals referred to in my analysis (especially because of the focus on their actions rather than on the staff themselves). ${ }^{34}$

\section{Analysis}

To provide some indication of how I arrived at my conclusions, this final section reviews how the data were analysed.

Prior to entering the field, I had little direct experience of the workings of an EPCC, but I had acquired some indirect knowledge by reading policy documents and scholarly works on EDs (cf. Dodier and Camus 1998; Jeffery 1979; Roth 1972; Vassy 2001). To prepare for fieldwork, I had also reviewed descriptive studies of nurses' decision-making in triage (Johannessen 2016). Nevertheless, on entering the field, it seemed quite exotic and unfamiliar.

Theoretically, I was less of a blank slate. I consider myself relatively well versed in interpretivist sociology, and I was given a quite thorough introduction to the sociology of professions following admission to the $\mathrm{PhD}$ programme at the Centre for the Study of Professions. Consequently, I entered the field with certain sensitising concepts (Blumer 1954) in mind, such as categorisation, discretion, jurisdiction, prioritisation, standardisation and valuation. While these proved central for the dissertation articles, I should add that I tried to

\footnotetext{
${ }^{34}$ To reduce the risk of informants being recognised by their colleagues, I have given them different pseudonyms across the different articles.
} 
maintain some degree of theoretical open-mindedness when in the field. (This arguably enabled me to write the second article, pertaining to workplace learning - a topic with which I had almost no prior familiarity).

During data collection, much of the analytical work was done by writing and reflecting on field notes. However, as I wrote my notes chronologically, I found it increasingly difficult to see patterns across all the different settings, people and conversations (along with the interspersed methodological and analytical reflections). One month into the fieldwork, I therefore resorted to QSR NVivo 10 to impose some order on my notes. Using so-called 'broad-brush' coding (Bazeley 2007: 67), I sorted the data into broad, fuzzy and inductive categories while reading through my notes. I also used NVivo to annotate and reflect on elements of interest, and to write analytical memos planning future fieldwork sessions and reflecting on empirical, theoretical and methodological issues.

On completing the fieldwork, I had coded all but three field notes. At this point, I decided to take a step back and re-read all my notes in NVivo, both to gain an overview of the data and to ensure that the broad-brush codes were exhaustively applied. I also decided to inductively summarise my material using NVivo’s annotation function. This was a laborious process, involving a total of 3,600 annotations, each comprising 1-5 statements that summed up the annotated content, often supplemented by brief analytical comments. In total, this took about one and a half months; although I remain undecided as to whether this was the most efficient use of my time, it did leave me with in-depth knowledge of my data and a richly commented and annotated data set.

There followed a more concentrated effort to produce the dissertation articles. While I had yet to decide to focus exclusively on standardisation and discretion in triage, I was by now convinced that the first article should explore nurses' discretionary use of guidelines (as this had been especially salient during my time in the field). In retrospect, I believe this choice significantly sharpened the focus of the dissertation. For instance, it was the in-depth analytical work with this data that made me truly aware of the workplace learning explored in the second article, and of the discretionary practices explored more thoroughly in articles 3 and 4. This initial article-centred work therefore had significant ramifications for the dissertation as a whole.

In developing each article, I adhered largely to the principles of thematic analysis (Braun and Clarke 2006; Clarke and Braun 2014). This much used but rarely acknowledged method of 
data analysis consists of four general phases: familiarisation, coding, categorisation and writing up one’s analysis (each with highly permeable boundaries).

Familiarisation means developing a general understanding of the data (Braun and Clarke 2006: 77). In my analyses, this turned out to be a two-stage process. The first stage involved familiarisation with the data set as a whole, mainly through broad-brush coding and annotation as mentioned above. The second stage involved familiarisation with the data of relevance to each article. This involved first identifying the broad brush codes of relevance for the article topic (adopting a generously inclusive approach to avoid missing any relevant data), and then skimming these coded data and their annotations to gain some sense of the topic as a whole.

Once the relevant material was in place and I had some sense of its totality, I proceeded to a more in-depth coding phase that went significantly beyond the broad-brush labels in the first round of sorting. Braun and Clarke (2006: 83-4) leave it to the researcher to decide whether coding should be inductive or deductive; as I wanted to ground my conclusions firmly in data, I opted for an inductive, data-driven strategy. To some extent, I had already coded my data inductively using the aforementioned annotations. However, as I discovered that these were too general and unfocused to provide any adequate insight into important details, I engaged in another inductive round of coding. This involved line-by-line reading, highlighting and summarising, coupled with analytical notes written along the way. Initially, I sought to ensure that my coding scheme was rigidly defined and exhaustively applied, but this all too soon corroborated Peter Berger’s apt remark, "In science, as in love, a concentration on technique is likely to lead to impotence” (1963: 13; quoted in Mintzberg 2005: 10). Instead, I found it more creatively stimulating to engage in successive rounds of more impulse-driven coding, allowing myself more freedom to decide which data warranted deeper consideration and which to leave alone. To ensure that the coding was sufficiently thorough and systematic, I varied my focus between rounds, trying each time to attend to new aspects of the data.

When coding, I often found myself slipping into the third phase of thematic analysiscategorisation -involving the identification of overarching patterns in the data (Braun and Clarke 2006: 87-93). This too involved successive rounds of trial and error as I sorted data inductively into salient categories. In so doing, I inevitably crossed into the fourth and final phase of writing up the analysis. This was far too messy a phase to reconstruct in any orderly form here; suffice to say, those seemingly endless rounds of writing and rewriting proved 
central for developing new insights and making me aware of the many deficiencies in my coding and categorisation.

I should also note that the analysis was not purely inductive, as the findings and framing of each article were significantly influenced by my reading of the empirical and theoretical literature. Accordingly, it is more appropriate to refer to the analysis as an abductive process - that is, as a dialogue between data and theory, in which data influences the choice of theory, and theory facilitates the interpretation of data (Järvinen and Mik-Meyer 2017: 11; Swedberg 2017). It seems especially important to emphasise how theory helped me to gain sufficient analytical distance from the data. Having immersed myself for so long in the field, I found it very difficult at first to step back and reflect critically on what I had seen. In general, I tended to accept the unstated premises of nurses' sayings and doings, such as their approach to pain assessment. I would never have written the paper on pain assessment (article 4) had I not read Transcending the dualisms: towards a sociology of pain (Bendelow and Williams 1995) or The story of pain: from prayer to painkillers (Bourke 2014). Texts like these helped me depart from my informants' emic perspective to see their practices in a new light.

This links to a more fundamental methodological point: in ethnographic research, immersion is a means not an end. After all, the ethnographer both observes and participates in the social world under study, and the point is hardly to become one with one's informants; if this were so, ethnographers would regularly fail, as they would have "but a fleeting glimpse of matters known much more intimately, intensively and extensively” (Rock 2001: 31) by those under study. Instead, ethnographers participate for reasons that differ from those of their informants, working towards some intellectual goal that is typically of (at most) secondary interest to those being studied. While immersion and close attention to the data serve to prevent premature conclusions, ethnography should also involve going beyond actors’ own understanding (Turco and Zuckerman 2017). In this regard, I concur with Rock (2001):

\footnotetext{
What ethnography can contribute is a disciplined unravelling of the breadth and complexity of relations; it can ask questions unasked by actors on the social scene; it can pursue problems of little interest to those on the social scene; it can compare and contrast in ways that insiders do not; and it can be rigorous as others are not. (Rock 2001: 31)
}

With this in mind, we move on to the articles of the dissertation. 


\section{Chapter 5: Article summaries}

This chapter provides a brief overview of the articles of this dissertation. While each contributes empirically and theoretically to somewhat different literatures, all relate to standardisation and discretion in triage, and this common thread is highlighted here.

\section{Article 1: 'Beyond guidelines'}

Johannessen, L.E.F. (2017). Beyond guidelines: Discretionary practice in face-to-face triage nursing. Sociology of Health \& Illness 39(7): 1180-1194.

Article 1 provides an in-depth account of the decoupling between MTS prescriptions and nurses' actual categorisation of patients. The analysis shows first how nurses assessed patients at odds with MTS prescriptions by collecting supplementary data, engaging in differential diagnostic and holistic reasoning, relying on emotion and intuition and allowing colleagues and patients to influence their reasoning. The article goes on to explore why, when and how nurses departed from the MTS in setting priorities. Concerning why, nurses (and other staff) considered the MTS too imprecise for sorting a large number of patients according to finegrained clinical needs. Concerning when, triage nurses disregarded the MTS primarily when they believed that to follow its prescriptions would entail an unreasonable wait for the patient. Finally, concerning how, the article shows that nurses resorted to both overt and covert methods in departing from the MTS' recommendations. Overt methods were most commonly deployed when upgrading a patient's triage code, as this was largely considered legitimate within the clinic; covert methods, on the other hand, were used primarily when engaging in the formally less legitimate act of downgrading a patient's triage code. Finally, the article shows that nurses' assessments were not wholly independent of the MTS; instead, the guidelines served as a support system and checklist, and as a system for supervisory control.

Overall, the article reveals a significant decoupling between nurses' assessments and MTS prescriptions. On this basis, it is argued that nurses relied less on the MTS guidelines than on 'mindlines' (Gabbay and le May 2011) when assessing the urgency of patients' complaints. The concept of triage mindlines denotes the guiding principles internalised from professional socialisation and personal experience, as well as from interaction with colleagues, triage instructors, management, the MTS and other sources. As these mindlines structure the triage encounter in terms of a more situated, particularistic logic than the abstract procedural prescriptions of the MTS, they allow nurses to set priorities in a more fine-grained manner. In 
sum, the article highlights the crucial role of additional skills and knowledge in making guidelines work, as well as some barriers salient to the streamlining of clinical practice.

\section{Article 2: 'Workplace assimilation and professional jurisdiction'}

Johannessen, L.E.F. (2018). Workplace assimilation and professional jurisdiction: How nurses learn to blur the nursing-medical boundary. Social Science \& Medicine 201: 51-58.

Article 2 explores how nurses developed the knowledge underpinning the discretionary practices described in the first article. It beings by detailing how the MTS articulates professional boundaries between nurses and physicians in the EPCC, and then goes on to explore how nurses’ workplace learning contributes to the blurring of these boundaries. Specifically, the article highlights four salient learning mechanisms: (1) doing physician-like work in triage and other clinical roles; (2) interacting with colleagues in relation to medical topics; (3) comparing triage assessment to the physician's clinical assessment (as codified in the patient record) and (4) using medical reference works as guides for clinical decision making.

In sum, these learning mechanisms contribute to workplace assimilation in the EPCC, as workers in one profession (nursing) learn to undertake some of the work tasks of another (medicine) in an informal capacity. The MTS plays a central role in this assimilative process, as nurses internalise the system through repeated practice. However, nurses acquire more than the explicit knowledge of the MTS; the assimilative process also involves the development of important tacit skills, along with the confidence to depart from formal guidelines. As nurses' superiors were to some extent aware of this workplace learning, they also considered nurses' discretionary practices - including some forms of downgrading - to be warranted if the nurse was sufficiently experienced and had clinically sound reasons for departing from the MTS. In other words, then, this article identifies several factors that both enabled and legitimised nurses' departures from the guidelines.

\section{Article 3: 'Narratives and gatekeeping'}

Johannessen, L.E.F. (2018). Narratives and gatekeeping: Making sense of triage nurses’ practice. Published online ahead of print in Sociology of Health \& Illness.

While articles 1 and 2 provide an overview of nurses' discretionary practices as a whole, article 3 takes a closer look at one specific practice: turning patients away from the EPCC. Linking to studies of so-called 'inappropriate attenders' in emergency services, the article 
focuses on a particular subcategory variously referred to in this context as 'trivia', 'GP patients' or 'green patients' (the latter referring to the triage code typically assigned to these patients). While green patients are formally eligible for EPCC treatment, nurses sought to make more fine-grained distinctions and commonly attempted to turn these green patients away.

By highlighting this discretionary practice, the article shows how nurses’ informal categories crisscrossed and overruled the formal categories of the MTS. In addition, the article hermeneutically reconstructs nurses' reasons for engaging in this practice. Combining observations of gatekeeping practices with a narrative analysis of nurses' accounts, several concerns are highlighted. Among these, one cluster of narratives framed nurses’ gatekeeping as a way of helping the patient that is turned away. These accounts typically related to patients who attend at busy times and who, because of their low-priority triage code, would have to wait for several hours before receiving medical attention. Another narrative cluster centred on how admitting 'GP patients' might negatively affect EPCC work: first, because 'GP patients', by their sheer number, add to nurses' burden and make it harder to take care of those who are really ill; and second, because 'GP patients' were considered particularly inclined to complain or 'nag' while waiting. A third cluster of narratives focused on how 'GP patients' constituted a threat to the EPCC as an institution. In short, many 'GP patients' were perceived as 'abusing' the EPCC's openness, and because they attend in such large numbers, they were also seen to threaten the institutional boundary between the EPCC and GP services. In reconstructing this wide range of reasons, the article illuminates how these patients were perceived and why nurses overruled guideline recommendations to turn them away.

\section{Article 4: 'The commensuration of pain'}

Johannessen, L.E.F. (forthcoming). The commensuration of pain: How nurses transform subjective experience into objective numbers. Under review in Social Studies of Science.

The fourth and final article zooms in on another discretionary practice: how nurses assign pain scores in triage. The MTS requires nurses to score patients' pain intensity on the Numeric Rating Scale (NRS), an 11-point scale ranging from zero ('no pain') to 10 ('the worst pain imaginable'). ${ }^{35}$ The MTS also specifies that nurses should score pain by combining their own assessment with the patient's self-reported pain rating, which nurses

\footnotetext{
${ }^{35}$ As mentioned in the article, the NRS scores map onto the urgency levels of the MTS: 0 corresponds to a 'blue' priority, 1-4 is 'green', 5-7 is 'yellow', and 8-10 is 'orange'.
} 
referred to as ‘objective and ‘subjective’ NRS, respectively. However, nurses did not usually adhere to guideline prescriptions; instead of combining the two ratings, they relied almost solely on the 'objective' NRS, asking patients to self-report their pain score only when the ‘objective’ NRS was considered ambiguous or inconclusive.

The article explores why nurses disregarded 'subjective' NRS, and what their alternative 'objective' approach entailed. It became clear that nurses considered 'subjective’ NRS too imprecise and inconsistent for ranking patients by urgency, illustrating how a standard can be considered unfit for the situation it is meant to standardise. Concerning the nurses' alternative approach, the article shows that the MTS offered little guidance in relation to how an 'objective' assessment should be performed, and that the nurses 'filled in the blanks' of the MTS by referring to their own principles, methods and knowledge. In this regard, the nurses relied on 'objective' signs of pain such as the patient's physiology, body language and functional capacity; a range of techniques for uncovering 'unreliable' expressions of pain; and fixed end-points of the pain scale, such as 'birth pains' or 'torture', which the nurses used as 'objective' yardsticks. The nurses' 'objective' approach selectively transformed pain to the advantage of some patients and the disadvantage of others. The article argues that this approach must be understood in relation to situational constraints; put simply, nurses had to make rapid judgments about complete strangers under stressful conditions, which imposed significant limitations on pain assessment. In summary, the article provides an in-depth account of the interplay between standardisation, discretion and the situational requirements of triage. 


\section{Chapter 6: Discussion}

This chapter discusses what the present findings tell us about the relationship between standardisation and discretion in triage, as well as in street-level professional work more generally. To begin, the chapter reviews how the four articles together address the research questions. Along the way, I also discuss the promise, problems and pitfalls of standardisation and discretion in professional work. In conclusion, I discuss some limitations and possible avenues for further research.

\section{Between standardisation and discretion}

The first two research questions asked how and why triage nurses depart from the MTS when setting priorities. Concerning how, the previous chapter described the significant decoupling between MTS recommendations and nurses’ priority setting. Among other things, nurses regularly 'upgraded' or 'downgraded' patients' triage codes, and they frequently attempted to turn away those judged too 'trivial' for the EPCC. ${ }^{36}$ Nurses also employed a more finegrained system of categorisation than the MTS, sorting patients into a range of sub-categories (e.g. 'GP patients') and drawing more gradual distinctions between urgency categories. ${ }^{37}$

What accounts for these actions? From a regulatory, top-down perspective, these could be perceived as nurses 'shirking', engaging in 'sabotage' or otherwise failing to meet their responsibilities (cf. Brehm and Gates 1997). From a bottom-up perspective, however, it is evident that nurses' departures from the guidelines were differently motivated. In the nurses' view, the MTS was too imprecise for prioritising patients-especially in this crowded clinic, where they had to sort a large number of patients according to fine-grained clinical needs. With possible post-triage waiting times of several hours, there could be serious consequences if a case of critical illness was overlooked, or if too many non-critical patients were assigned urgent triage codes, making it harder to spot the most critically ill. To avoid such problems, nurses worked to render assessments 'thicker’ by supplementing the MTS with their professional and everyday knowledge, adjusting priorities accordingly. Thus, in departing from the guidelines, nurses were pursuing largely the same goals as the MTS - the correct and consistent prioritisation of patients. In the words of Maynard-Moody and Musheno (2012: S20), nurses were 'conservers', defending institutional values and goals, rather than 'rogue

\footnotetext{
${ }^{36}$ In the terms of the MTS, turning away patients meant informally downgrading patients to the lowest triage code, blue, which could legitimately be advised to seek help elsewhere.

${ }^{37}$ As seen in nurses' intra-code adjustments, which involved changing a patient's relative priority within the MTS-recommended triage code (see article 1).
} 
agents' seeking to advance any personal agenda. ${ }^{38}$ Taking a bottom-up approach has thus helped foreground the content and rationale of nurses’ practice, highlighting the limitations, compromises and informal solutions on which ground-floor healthcare delivery depends.

At the same time, the bottom-up approach should not blind us to the broader context of nurses' discretionary practices. For instance, the practice of turning 'GP patients' away must be understood in light of such factors as EPCC resource constraints; the division of labour between EPCCs and GP services (and the problems many patients face in making appointments with the latter, see Sandvik et al. 2012); and the interaction between open, walkin EPCCs and patients with certain beliefs, opportunities and expectations (cf. Roth 1971; Wolcott 1979). Similarly, the requirement to use a triage system in the first place must be understood in the context of jurisdictional boundaries in healthcare (Abbott 1988); internal and external demands for evidence-based practice, equity and quality control (Timmermans and Berg 2003); and the pervasive influence of bureaucratic norms and values (cf. Mik-Meyer 2017).

However, approaching these factors as experienced and negotiated on the ground floor reveals nuances that may escape more macro-level accounts. For instance, this introduces important gradations to ‘top-down' claims about homogenisation and deprofessionalisation in streetlevel work mentioned above (cf. Haug 1988; Howe 1991; Ritzer 1993), which tend to neglect street-level possibilities for discretion and, indeed, how the appropriate use of guidelines depends on additional skills and knowledge (cf. Berg 1997a). ${ }^{39}$ The findings also call into question the many macro-level studies assessing the validity and reliability of triage guidelines. Using quantitative designs, these studies measure the relationship between triage systems and various outcome measures, such as admissions, discharges and death rates (cf. Brillman et al. 1996; Dent et al. 2007). Although important when testing and improving triage systems, such studies tend to overlook the nurse's use of the system and the process by which decisions are actually made. As the present findings indicate, these issues are crucial for understanding triage, and in treating them as 'black boxes', such studies may significantly misrepresent the effects of triage systems (for a similar argument, see Fry and Burr 2002).

\footnotetext{
${ }^{38}$ For the case in question, this seems more helpful than the distinction between 'stage agent' and 'citizen agent' (Maynard-Moody and Musheno 2003) often mentioned when discussing the actions of street-level bureaucrats (cf. Mik-Meyer 2017: 65-9).

${ }^{39}$ The need for additional skills and knowledge was unavoidably clear to this clinically illiterate sociologist; even with the guidelines in front of me, I rarely managed to reach the same conclusion as the nurses during triage.
} 
More generally, the bottom-up approach helps reveal the complex and ambiguous relationship between standardisation and discretion in professional work at street level. For instance, we have seen how EPCC management acknowledged the need for additional skills and knowledge to make the MTS work and so allowed nurses some leeway to depart from the system. This managerial stance is not uncommon; indeed, professional work is often more loosely regulated than it seems from the outside, as there is often tension between the need for skill-based judgment and the regulatory desire for transparency, monitoring and accountability (cf. Evans and Harris 2004; Flynn 2002; Russell 2012). Among other things, this calls into question the 'hole in the doughnut' metaphor mentioned above, where discretion denotes “an area left open by a surrounding belt of restrictions” (Dworkin 1978: 31, see also Chapter 3). Seen from the ground floor, formal boundaries are typically less clear-cut than the doughnut metaphor suggests; indeed, for nurses in this EPCC, their discretionary space was characterised less by the clear edges of a doughnut and more by the blurred transitions of a watercolour painting. Accordingly, a street-level perspective helps to illuminate how organisational policy is often more ambiguous and contradictory than a macro-level perspective would have us believe (cf. Abbott 1988; Bechky 2003; Lipsky 1980).

Beyond this, the bottom-up approach has also taught us that nurses could depart from the guidelines even if management had demanded strict adherence. In part, this reflects the absence of direct supervision, which meant that many deviations could go unnoticed. Furthermore, the guidelines often left significant room for discretion, as for instance in the MTS' very 'thin' prescriptions for assessing pain (as described in article 4). The dissertation also shows how more clear-cut criteria could be circumvented by creative use of covert practices. As described in article 1, nurses worked to shape and extend their discretionary space, using their extensive knowledge of the MTS to reflexively navigate its prescriptions. Their practice illustrates a central interactionist point: that actors are not simply shaped, conditioned or controlled by their surroundings but are active and creative agents who define, act on and use their environment (Charon 2004: 41). In this way, nurses' street-level practice demonstrates the importance of supplementing a 'de jure' with a 'de facto' understanding of discretion, seeing not just what workers are allowed to do but also what they are able to do in practice (Evans 2010: 33, see also Chapter 3).

That said, it was also clear that the guidelines had consequences for nurses' work, which brings us to the dissertation's third question: how the MTS (as enforced in this particular clinic) influenced triage nurses’ priority setting. In answering this question, it is helpful to 
refer to Brunsson and Jacobsson's (2000) distinction between 'practising standards' (“changing practice to fit the standard” (2000: 128)) and 'standardising practice' (“changing the presentation of practice in accordance with the standard” (2000: 128)). As indicated, there were several examples of the latter and 'softer' form, where nurses altered how they presented their practice rather than the practice itself. Most significantly, as the categories of the MTS were deeply embedded in the formal order of the clinic, nurses regularly had to 'pigeonhole' their assessments into the MTS categories (as noted in article 1; see also Prottas 1979). ${ }^{40}$

At the same time, there were also many instances in which nurses could be said to 'practise standards' in aligning their practice with the prescriptions of the MTS. Despite some informal acceptance of deviations, the MTS was still considered the 'norm' for priority setting, and nurses were expected to follow it unless they had good reason not to (see article 2). Given its status as the 'norm', nurses had to be fairly convinced before departing from the MTS' recommendations; otherwise, they typically erred on the side of caution by adhering to system recommendations. In this way, as nurses were held accountable for any (detectable) departures from the MTS, the system did exert some influence on how they assessed patients. As shown in article 2, nurses could also internalise the MTS through repeated use, and it then became a stable reference point to build on and adjust to the particular patient. As others have argued, such reference points may help in organising incoming information and so "reduce the cognitive load on [...] the decision making process" (Weiss 2011: 378), in turn facilitating “an increase in the overall complexity of health care providers' work” (Timmermans and Berg 2003: 64). Furthermore, although levels of active use varied during assessments, nurses often consulted the MTS towards the end to see if they had forgotten to check for relevant symptoms and signs. They also considered it helpful in situations where they were unsure how to assess a particular complaint. According to management, the MTS had also helped to establish a shared clinical language for talking about patients and their complaints, so contributing to ‘terminological’ standardisation (Timmermans and Berg 2003: 25). From a sociological perspective, then, the MTS contributed to changing both practice and the presentation of practice in a number of interesting ways.

These findings largely align with other reported experiences from the field. For instance, a report from the Norwegian National Advisory Unit on Prehospital Emergency Medicine

\footnotetext{
${ }^{40}$ Nurses often assigned a patient a triage code and then pondered what discriminator they could use to 'justify' their priority setting (as in the introductory vignette). In so doing, they maintained the appearance of following the system, so masking the degree of decoupling between the MTS and their actual assessments.
} 
recounts EMS workers' experience that triage guidelines improve patient security by virtue of more systematic assessment, more consistent documentation and enhanced cooperation and communication between different EMS actors (Halvorsen et al. 2014: 5). Similar positive experiences were noted in the present study, which shows that although guidelines may fail to completely codify and streamline processes, they may still ease interactions between workers and serve useful functions as checklists and reminders.

Interestingly, these functions have received little mention in the bottom-up studies of triage referred to in Chapter 1 (cf. Greatbatch et al. 2005; Hanlon et al. 2005; Wahlberg et al. 2003), which have tended instead to focus on guidelines’ limitations and how they hinder professional discretion. While that focus may be warranted on a study-by-study basis, the sum of negatively framed studies seem to suggest a lack of interest in guidelines’ potential to make positive contributions to clinical work.

Moreover, in arguing for the importance of discretion in clinical assessments, these studies have also tended to overlook its potential downsides. As this dissertation demonstrates, discretionary practice can bring its own problems. For instance, while the gatekeeping documented in article 3 is evidence of nurses trying to adjust the guidelines to prevent too many admissions to the EPCC, the article also reveals certain assumptions, expectations and generalisations that may negatively affect how nurses receive and treat those identified as 'GP patients'. Similarly, in article 4, while nurses had good reasons for disregarding the guidelines, their own discretionary approach to pain assessment had some shortcomings, such as disadvantaging patients with 'different ways' of expressing pain. Looking beyond the case in question, Timmermans' (1999) study of resuscitation attempts showed how staff's discretionary assessments meant that those of low social worth (e.g. drunks, drug addicts, older people) were much more likely to be considered 'socially dead'—that is, "treated essentially as a corpse, though perhaps still ‘clinically' and 'biologically' alive” (Sudnow 1967: 74) — as compared to the young, famous or identifiable. Clearly, then, healthcare workers' 'policy as performed' (Lipsky 1980: xvii) can have some troubling consequences. Discretion always carries with it the potential for arbitrariness, discrimination and faulty reasoning, and it poses a genuine problem in terms of democratic control and accountability (Molander 2016: 12-7).

However, this is not to say that the use of discretion is always problematic; as Evans and Harris argued, “discretion in itself is neither 'good' nor 'bad'. In some circumstances it may be an important professional attribute, in others it may be [...] an opportunity for professional 
abuse of power” (2004: 871). The point is rather that we should be wary of producing overly one-sided accounts of discretionary practice. Instead of approaching such practices as predominantly good or bad, studies of standardisation should remain open to both the problems and the potential of discretionary practice, exploring these with an open mind and on a case-by-case basis.

\section{Dealing with discretion}

In light of these potential pitfalls, it is worth taking a step back to reflect briefly on how the problems of discretion can be reduced. One standard answer is guidelines, but, as we have seen, these have significant limitations when it comes to streamlining clinical practice-for instance, rules are vague and not exhaustive, and work may not be closely supervised. Some of these limitations could perhaps be overcome by developing more comprehensive guidelines and enforcing these by means of increased monitoring and sanctions. However, this too has its limitations, as much assessment work is too indeterminate and complex to be codified in guideline prescriptions (cf. Timmermans and Berg 2003); indeed, as Berg (1997a) suggests, demanding strict adherence to guidelines can have its own adverse consequences:

Protocols are and cannot be anything but a set of rules which, as ethnomethodology has taught us, have to be made relevant to each and every situation at hand (Garfinkel, 1967; Suchman, 1987). If a protocol ties in the health care worker too firmly, if health care workers lose the skills and abilities to tinker with them, to adjust them to the ongoing flow of contingencies that characterises medical work-then this will inevitably lead to a loss of efficiency and quality of care. (Berg 1997a: 1087, italics in original)

This description resonates well with the present findings; had nurses been required to follow the MTS unquestioningly, this would have been to the detriment of both staff and patients. While guidelines may confer many advantages (e.g. as support tools and checklists), there are significant limits to how thoroughly they can prescribe clinical practice. There will always be a need for rendering 'thin’ guidelines ‘thicker' by applying situated judgment, especially in a complex area like clinical assessment, which can be fraught with contingencies and ambiguity. Accordingly, workers should be allowed some leeway in how they use guidelines; indeed, as Timmermans and Epstein concluded in their review, "The trick in standardization appears to be to find a balance between flexibility and rigidity and to trust users with the right amount of agency to keep a standard sufficiently uniform for the task at hand" (2010: 81).

From the standpoint of guideline developers and managers, this need for flexibility may seem counterintuitive, but it is closely linked to the idea of employing street-level bureaucrats and professionals to begin with. As Prottas makes clear, workers "are employed in this role 
because, for reasons of policy or practicality, the categorization of clients into organizationally processible terms cannot be highly simplified. Human judgment is required” (1979: 91). It follows that the problems of discretion cannot be solved by trying to eradicate the use of discretion itself, as this is likely to lead to dysfunctional services and/or creative circumvention by professionals. Instead, the aim should be to ensure that discretion is used in a reasonable and conscientious manner. How this might be accomplished is beyond the scope of this dissertation, but two general points can be noted.

The first concerns the importance of adopting a comprehensive view of accountability in street-level bureaucracies and professional work (Brodkin 2008; Hupe and Hill 2007; Molander 2016). As we have seen, management and external actors face significant challenges in holding professionals accountable for their use of discretion (e.g. because the latter work largely unsupervised and rely on tacit knowledge when making judgments). However, this does not mean that professionals are free to do as they please. As Hupe and Hill have argued, street-level bureaucrats are always held accountable in "more ways than strictly from the political centre alone” (2007: 296). Among other things, these authors emphasise the importance of 'professional accountability' (Hupe and Hill 2007: 289-90), referring to how street-level workers consider themselves accountable to broader networks of fellow professionals, including their colleagues, peers and vocational associations. The importance of such networks was apparent in the clinic under study, where nurses attached great significance to how they were perceived by colleagues. Accordingly, they seemed to approach triage assessments conscientiously, as this brought benefits such as professional recognition by their peers. Of course, like all other forms of accountability, this raises certain issues, such as workers' reluctance to report each other's errors due to norms of collegiality (cf. Bringedal et al. 2018; Padgett 2013). The point, however, is that debates about street-level practice could benefit from recognising the multiple avenues of accountability rather than confining discussion to the top-down relationship between regulators and professionals.

A second issue concerns the need to complement guidelines with competent healthcare workers. While this is no 'quick fix', it is an inescapable requirement in limiting the problems associated with professional discretion. As Mintzberg (1979) argued, solutions to professional problems must grow

from a recognition of professional work for what it is. Change in the Professional Bureaucracy does not sweep in from new administrators taking office to announce major reforms, nor from government technostructures intent on bringing the professionals under control. Rather, change seeps in, by the slow 
process of changing the professionals_changing who can enter the profession, what they learn in its professional schools (ideals as well as skills and knowledge), and thereafter how willing they are to upgrade their skills. (Mintzberg 1979: 379)

In short, to meet the complex demands of professional work, procedural standards must be complemented by competent workers who can adapt them conscientiously to the relevant circumstances.

Rather than relying solely (or chiefly) on guidelines, then, we must pursue more comprehensive solutions to minimise the problems associated with discretion. While this may seem an obvious point, it is worth emphasising in light of the many challenges facing the healthcare systems of Norway and similar countries-including an older population and the concurrent increase in chronic illness, as well as the new and costly treatments that are constantly being introduced (cf. Hjort 2006; NOU 2014: 34-49). There is widespread agreement that such developments pose significant budgetary challenges, and one tempting way of cutting costs may be to couple comprehensive guidelines with 'cheaper' and less competent staff (cf. Lipsky 2010: 172-9). Additionally, there is always the risk that standards may render professionals vulnerable to external regulation, where the state or other actors try to reduce flexibility in order to streamline professional practice (cf. Harrison 2015: 66-7; Timmermans 2005). While staff may resist external regulation of that kind, it can nevertheless add unnecessary costs to their already challenging work, potentially creating perverse incentives and damaging patients. For that reason, it is crucial to recognise the limits of procedural standards and the dangers of demanding unquestioning adherence to them.

\section{Limitations and future research}

Before concluding, I will reflect briefly on this dissertation's limitations, and on how these might guide further research into standardisation and discretion. First, the present research explores a particular standard in a particular setting. The MTS is an algorithmic triage system that aims to provide a near-exhaustive codification of the decision-making process (see Chapter 2), and it was studied in a crowded, public walk-in organisation, where nurses spend 4-8 minutes on each patient, assessing fairly complex medical problems under little direct supervision. As such, this dissertation tells $a$ story, not the story, about the procedural standardisation of professional work.

While the findings concerning guideline departures resonate well with other studies of triage and clinical assessment work (cf. Dowding et al. 2009; Greatbatch et al. 2005; O'Cathain et al. 2004; Ruston 2006), it is difficult to draw strong inferences about the structural 
foundations of these similarities. Relevant factors seem to include high workloads, complex assessments, non-exhaustive guidelines and lack of direct supervision. However, more comparative research is needed if we are to make stronger generalisations about the relationship between guidelines, deviations and context. Among other things, it would be important to compare different types of guidelines, workers, organisations and institutional arrangements (for inspiration, see Collin-Jacques and Smith 2005). In relation to different types of guidelines, there is also a need to differentiate the category of 'procedural standards' itself. Berg's definition illustrates this, as it groups standards that are "more or less elaborate, precise, or binding” (1997a: 1081). While useful as an umbrella term, we are likely to gain analytical traction by identifying salient sub-categories of procedural standards, varying along such dimensions as aims, content and elaboration.

An additional limitation relates to the choice of methods and to my own lack of clinical knowledge, which prevented me from drawing strong conclusions about the quality of nurses' discretionary practices. While there is a substantial literature on the validity and reliability of triage nurses' assessments, we have seen how this literature focuses on decision making outcomes rather than processes, and there is a need for more evaluative research that takes account of what nurses actually do when performing triage assessments.

Additionally, the detailed analyses of triage nurses' practices precluded more in-depth analysis of their relationships with other actors. These relationships may significantly influence nurses' guideline deviations; for instance, intra-code adjustments were wholly dependent on the nurse coordinator, and turning patients away typically depended on whether other organisations were open and available. Closely related, while patients' influence on triage assessments has been mentioned in several of the articles in this dissertation, their impression management and negotiation also warrants more detailed study, as this is typically of great importance in clinical decision making (cf. Heritage and Maynard 2006). Moreover, in focusing so closely on the MTS, this dissertation has not been able to delve deeply into how this was nested into other standards (Lampland and Star 2009). ${ }^{41}$ And lastly, the bottomup approach has costs as well as pay-offs; in particular, I was unable to fully explore how nurses' practices were embedded in a wider organisational and institutional context. Further studies of standardisation are therefore needed to examine more closely how the (non-)use of

\footnotetext{
${ }^{41}$ Exceptions include article 1, where I make brief mention of how the MTS was in some tension with nurses' standard for documentation, SBAR, and article 4, where I zoom in on the Numeric Rating Scale, a standard for pain rating that was nested into the MTS.
} 
guidelines is contingent on broader networks of actors, objects and institutions (cf. Rapley 2008), and how this, among other factors, may challenge overtly individualist conceptions of responsibility and accountability in the healthcare services (cf. Goodwin 2014).

Finally, it is worth noting that, like virtually all other studies of standardisation, this dissertation focuses on manually created guidelines - that is, guidelines created by experts in an attempt to codify the most important concerns when performing a particular task. Until recently, this was the gold standard for standard creation (Timmermans and Berg 2003), but recent advances in machine learning may lead to the emergence of a different form of guideline. Put simply, machine learning means developing computer programs that can gradually 'learn’ (through repeated trial-and-error analysis of large data sets) how to solve a particular task (Mitchell 1997). Under ideal conditions, these programs can significantly outperform humans in pattern recognition and prediction (Brynjolfsson and Mitchell 2017)and as the emerging 'sociology of machine learning' (Stilgoe 2018) suggests, this technology raises several questions about autonomy, accountability and the relationship between humans and machines. There is some evidence of the successful use of this technology in triage (Levin et al. 2017). If machine learning-based guidelines become more widespread, we can expect a general shift in the relationship between standardisation and discretion in professional work, with departures from guidelines perceived as increasingly unacceptable. In any case, this seems a fruitful avenue for future studies of standardisation.

\section{Conclusion}

This dissertation has explored the relationship between standardisation and discretion in professional work at street-level, using the priority setting of triage nurses as its case. Its point of departure was the author's fieldwork in a Norwegian EPCC, where triage nurses were required to assess patients using the Manchester Triage System. Observations revealed that nurses regularly departed from MTS recommendations but also seemed to be influenced by the system in a number of ways. On this basis, the dissertation examined how and why nurses departed from the MTS and, conversely, how the MTS influenced their priority setting. Together, the four articles of the dissertation show how nurses supplemented the MTS with additional skills and knowledge, leading them to adjust and override the formally prescribed priorities of the MTS. While they had several reasons for doing so, their primary concern was to 'correct' the MTS and to ensure more precise prioritisation of patients. However, by restricting, enabling and supporting priority setting, the MTS also played a significant role in their assessments. 
As well as shedding light on triage nurses' discretionary practices, this dissertation makes three more general contributions to the sociology of standardisation. First, the dissertation helps to bridge the gaps between the sociology of standardisation and the literatures on streetlevel bureaucracy and categorisation. In so doing, the dissertation identifies fruitful theoretical linkages for future studies of standardisation and discretion in street-level categorisation of clients. Secondly, through in-depth inquiry into nurses' use of the MTS, the dissertation provides a rich account of the difficulties of streamlining clinical practice. Despite its elaborate design, the MTS was too 'thin' to match the complexity of triage nurses' work, and following it unreflectively would have been detrimental for both patients and staff. Nurses therefore had to render the guidelines 'thicker' through situated judgments, illustrating the crucial role of additional skills and knowledge in making standards work. Finally, the dissertation also shows how the MTS (despite its shortcomings) affected nurses’ work in several ways, so answering Timmermans and Berg's (2003) call for further research on how guidelines interact with professional practice. By transcending the either/or language that characterises much research on standardisation, the dissertation provides a nuanced account of the interplay between prescribed and discretionary aspects of triage nursing.

Overall, this dissertation highlights both problems and potentials for the procedural standardisation of professional work. Hopefully, these findings can serve to underline the limitations of dichotomous thinking about standards—of seeing them as either good or bad, functional or dysfunctional. Instead, researchers should approach standards with an open mind, with a view to empirically unpacking their complexity. Regulators should view standardisation and discretion less as a zero-sum game than as two ends of a scale, whose balance must be adjusted to the task in hand. Educators should sensitise students to the potential shortcomings of guidelines, underlining the importance of 'tinkering' to make them work. Finally, workers should be encouraged to be open about their discretionary practices, and to reflect openly on their blind spots and unintended consequences. Only by facing this complexity head on, acknowledging the need for both standardisation and discretion, can we hope to see improvements in professional practice. 


\section{References}

Abbott, A. (1988) The system of professions: an essay on the division of expert labor. Chicago: University of Chicago Press.

Album, D. (1996) Nære fremmede: pasientkulturen i sykehus. Oslo: TANO.

Allen, D. and Hughes, D. (2002) Nursing and the division of labour in healthcare. Palgrave.

Anspach, R.R. (1987) Prognostic conflict in life-and-death decisions: The organization as an ecology of knowledge, Journal of Health and Social Behavior. 28, 3, 215-31.

Ashforth, B.E. and Humphrey, R.H. (1997) The ubiquity and potency of labeling in organizations, Organization Science. 8,43-58.

Atkinson, P. and Coffey, A. (2003) Revisiting the relationship between participant observation and interviewing. In Holstein, J.A. and Gubrium, J.F. (eds.) Inside interviewing. New lenses, new concerns. Thousand Oaks, Calif.: SAGE. pp. 415-28.

Atkinson, P., Coffey, A., Delamont, S., Lofland, J., et al. (2001) Handbook of ethnography. SAGE Publications Ltd.

Barnes, B., Bloor, D. and Henry, J. (1996) Scientific knowledge: a sociological analysis. London: Athlone.

Bazeley, P. (2007) Qualitative data analysis with NVivo. Los Angeles: Sage.

Bechky, B.A. (2003) Object lessons: Workplace artifacts as representations of occupational jurisdiction, American Journal of Sociology. 109, 3, 720-52.

Becker, H.S. (1963) Outsiders: studies in the sociology of deviance. London: Free Press.

Becker, H.S. (1996) The epistemology of qualitative research. In Jessor, R., Colby, A., and Shweder, R.A. (eds.) Ethnography and human development: context and meaning in social inquiry. Chicago: The University of Chicago Press. pp. 53-71.

Bendelow, G.A. and Williams, S.J. (1995) Transcending the dualisms: towards a sociology of pain, Sociology of Health \& Illness. 17, 2, 139-65.

Berg, M. (1997a) Problems and promises of the protocol, Social Science \& Medicine. 44, 8, 1081-8.

Berg, M. (1997b) Rationalizing medical work. Cambridge: MIT Press.

Berg, M., Horstman, K., Plass, S. and Van Heusden, M. (2000) Guidelines, professionals and the production of objectivity: standardisation and the professionalism of insurance medicine, Sociology of Health \& Illness. 22, 6, 765-91. 
Berger, P.L. and Luckmann, T. (1966) The social construction of reality: a treatise in the sociology of knowledge. Garden City, N.Y.: Anchor Books.

Berkwits, M. (1998) From practice to research: The case for criticism in an age of evidence, Social Science \& Medicine. 47, 10, 1539-45.

Blaxter, M. (1978) Diagnosis as category and process: The case of alcoholism, Social Science \& Medicine. 12,9-17.

Bloor, D. (1997) Wittgenstein, rules and institutions. London: Routledge.

Blumer, H. (1954) What is wrong with social theory?, American Sociological Review. 19, 1, $3-10$.

Blumer, H. (1969) Symbolic interactionism: perspective and method. Englewood Cliffs, N.J: Prentice Hall.

Bosk, C.L. (2008) What would you do?: juggling bioethics and ethnography. Chicago: University Of Chicago Press.

Bourke, J. (2014) The story of pain: From prayer to painkillers. New York, NY: OUP Oxford.

Bowker, G.C. and Star, S.L. (1999) Sorting things out: classification and its consequences. Cambridge, Mass.: MIT Press.

Braun, V. and Clarke, V. (2006) Using thematic analysis in psychology, Qualitative Research in Psychology. 3, 2, 77-101.

Brehm, J. and Gates, S. (1997) Working, shirking, and sabotage: bureaucratic response to a democratic republic. Ann Arbor: University of Michigan Press.

Brillman, J.C., Doezema, D., Tandberg, D., Sklar, D.P., et al. (1996) Triage: limitations in predicting need for emergent care and hospital admission, Annals of Emergency Medicine. 27, 4, 493-500.

Bringedal, B., Rø, K.I., Magelssen, M., Førde, R., et al. (2018) Between professional values, social regulations and patient preferences: medical doctors’ perceptions of ethical dilemmas, Journal of Medical Ethics. 44, 4, 239-43.

Brodkin, E.Z. (2008) Accountability in street-level organizations, International Journal of Public Administration. 31, 3, 317-36.

Brodkin, E.Z. (2012) Reflections on street-level bureaucracy: past, present, and future, Public Administration Review. 72, 6, 940-9. 
Brodkin, E.Z. (2015) The inside story: street-level research in the US and beyond. In Hupe, P., Hill, M., and Buffat, A. (eds.) Understanding Street-level Bureaucracy. Bristol: Policy Press. pp. 25-42.

Bruce, K. and Suserud, B.-O. (2005) The handover process and triage of ambulance-borne patients: the experiences of emergency nurses, Nursing in Critical Care. 10, 4, 201-9.

Brunsson, N. and Jacobsson, B. (2000) A world of standards. Oxford: Oxford University Press.

Brynjolfsson, E. and Mitchell, T. (2017) What can machine learning do? Workforce implications, Science. 358, 6370, 1530-4.

Buffat, A. (2015) When and why discretion is weak or strong: the case of taxing officers in a Public Unemployment Fund. In Hupe, P., Hill, M., and Buffat, A. (eds.) Understanding Street-level Bureaucracy. Bristol: Policy Press. pp. 79-96.

Buvik, K. (2016) The hole in the doughnut: a study of police discretion in a nightlife setting, Policing and Society. 26, 7, 771-88.

Carter, E.J., Pouch, S.M. and Larson, E.L. (2014) The relationship between emergency department crowding and patient outcomes: a systematic review, Journal of nursing scholarship. 46, 2, 106-15.

Casper, M.J. and Clarke, A.E. (1998) Making the pap smear into the right tool for the job: cervical cancer screening in the USA, circa 1940-95, Social studies of science. 28, 2, 255-90.

Charon, J.M. (2004) Symbolic interactionism: an introduction, an interpretation, an integration. 8th ed. Upper Saddle River, N.J: Prentice Hall.

Clarke, V. and Braun, V. (2014) Thematic analysis. In Encyclopedia of Critical Psychology. Springer, New York, NY. pp. 1947-52.

Collin-Jacques, C. and Smith, C. (2005) Nursing on the line: Experiences from England and Quebec (Canada), Human Relations. 58, 1, 5-32.

Czarniawska, B. (2014) Why I think shadowing is the best field technique in management and organization studies, Qualitative Research in Organizations and Management: An International Journal. 9, 1, 90-3.

Dent, A., Rofe, G. and Guy, S. (2007) Which triage category patients die in hospital after being admitted through emergency departments? A study in one teaching hospital, Emergency Medicine. 11, 2, 68-71. 
Dobransky, K. (2009) The good, the bad, and the severely mentally ill: Official and informal labels as organizational resources in community mental health services, Social Science \& Medicine. 69, 5, 722-8.

Dodier, N. and Camus, A. (1998) Openness and specialisation: Dealing with patients in a hospital emergency service, Sociology of Health \& Illness. 20, 4, 413-44.

Douglas, M. (1966) Purity and danger: an analysis of concepts of pollution and taboo. London: Routledge.

Dowding, D., Mitchell, N., Randell, R., Foster, R., et al. (2009) Nurses’ use of computerised clinical decision support systems: a case site analysis, Journal of Clinical Nursing. 18, 8, 1159-67.

Durkheim, É. and Mauss, M. (1903) De quelques formes de classification - contribution à l'étude des représentations collectives, Année sociologique. 6,.

Durkheim, É. and Mauss, M. (1969) Primitive classification. London: Cohen \& West.

Dworkin, R. (1978) Taking rights seriously. London: Duckworth.

Emerson, R.M., Fretz, R.I. and Shaw, L.L. (2011) Writing ethnographic fieldnotes. Chicago: University of Chicago Press.

Espeland, W. and Stevens, M. (1998) Commensuration as a social process, Annual Review of Sociology. 24, 1, 313-43.

Espeland, W.N. and Stevens, M.L. (2008) A sociology of quantification, European Journal of Sociology / Archives Européennes de Sociologie. 49, 3, 401-36.

Etzioni, A. (1969) The semi-professions and their organization: teachers, nurses, social workers. New York, N.Y.: Free Press.

Evans, T. (2010) Professional discretion in welfare services: beyond street-level bureaucracy. London: Ashgate.

Evans, T. (2011) Professionals, managers and discretion: critiquing street-level bureaucracy, British Journal of Social Work. 41, 2, 368-86.

Evans, T. and Harris, J. (2004) Street-level bureaucracy, social work and the (exaggerated) death of discretion, The British Journal of Social Work. 34, 6, 871-95.

Fiske, S.T. and Taylor, S.E. (2013) Social cognition: from brains to culture. London: SAGE.

FitzGerald, G., Jelinek, G.A., Scott, D. and Gerdtz, M.F. (2010) Emergency department triage revisited, Emergency Medicine Journal. 27, 2, 86-92. 
Flynn, R. (2002) Clinical governance and governmentality, Health, Risk \& Society. 4, 2, 15573.

Foucault, M. (2003) The birth of the clinic: an archaeology of medical perception. London: Routledge.

Fowler, P.B.S. (1997) Evidence-based everything, Journal of evaluation in clinical practice. 3, 3, 239-43.

Freidson, E. (1994) Professionalism reborn: theory, prophecy, and policy. Chicago: University of Chicago Press.

Freidson, E. (2001) Professionalism: The third logic. Cambridge: Polity Press.

Friedman, J.R. (2009) The ‘social case’, Medical Anthropology Quarterly. 23, 4, 375-96.

Fry, M. and Burr, G. (2001) Current triage practice and influences affecting clinical decisionmaking in emergency departments in NSW, Australia, Accident and Emergency Nursing. 9, 4, 227-34.

Fry, M. and Burr, G. (2002) Review of the triage literature: Past, present, future?, Australian Emergency Nursing Journal. 5, 2, 33-8.

Fujimura, J.H. (1992) Crafting science: Standardized packages, boundary objects, and 'translation.', Science as practice and culture. 168,168-9.

Fukuyama, F. (2012) The origins of political order: from prehuman times to the French Revolution. Reprint edition. New York, NY: Farrar, Straus and Giroux.

Gabbay, J. and le May, A. (2011) Practice-based evidence for healthcare: clinical mindlines. London: Routledge.

Garfinkel, H. (1967) Studies in ethnomethodology. Englewood Cliffs, N.J: Prentice-Hall.

Geertz, C. (1973) Thick description: Toward an interpretative theory of culture. In Geertz, C. (ed.) The interpretation of cultures. Selected essays. New York: Basic Books. pp. 330 .

Gerdtz, M.F. and Bucknall, T.K. (2001) Triage nurses’ clinical decision making. An observational study of urgency assessment, Journal of Advanced Nursing. 35, 4, 55061.

Geyman, J.P. (1999) POEMs as a paradigm shift in teaching, learning, and clinical practice. Patient-Oriented Evidence that Matters., The Journal of family practice. 48, 5, 343-4. 
Gilboy, N., Travers, D. and Wuerz, R. (1999) Re-evaluating triage in the new millennium: A comprehensive look at the need for standardization and quality, Journal of Emergency Nursing. 25, 6, 468-73.

Goffman, E. (1989) On fieldwork, Journal of Contemporary Ethnography. 18,123-32.

Goodwin, D. (2014) Decision-making and accountability: differences of distribution, Sociology of Health \& Illness. 36, 1, 44-59.

Greatbatch, D., Hanlon, G., Goode, J., O’Cathain, A., et al. (2005) Telephone triage, expert systems and clinical expertise, Sociology of Health \& Illness. 27, 6, 802-30.

Halvorsen, K.S., Nilsen, J.E. and Olsen, J.Å. (2014) Triage i den akuttmedisinske kjeden (NAKOS report 2/2014).

Hanlon, G., Strangleman, T., Goode, J., Luff, D., et al. (2005) Knowledge, technology and nursing: The case of NHS Direct, Human Relations. 58, 2, 147-71.

Hansen, E.H. and Hunskår, S. (2016) Legevaktarbeid: en innføringsbok for leger og sykepleiere. Oslo: Gyldendal akademisk.

Hanson, N.R. (1958) Patterns of discovery: an inquiry into the conceptual foundations of science. 1st Paperback Edition edition. Cambridge: Cambridge University Press.

Harrison, S. (1998) The politics of evidence-based medicine in the United Kingdom, Policy \& Politics. 26, 1, 15-31.

Harrison, S. (2015) Street-level bureaucracy and professionalism in health services. In Hupe, P., Hill, M., and Buffat, A. (eds.) Understanding Street-level Bureaucracy. Bristol: Policy Press. pp. 61-78.

Haug, M.R. (1975) The deprofessionalization of everyone?, Sociological Focus. 8, 3, $197-$ 213.

Haug, M.R. (1988) A re-examination of the hypothesis of physician deprofessionalization, The Milbank Quarterly. 66,48-56.

Heritage, J. (1984) Garfinkel and ethnomethodology. Cambridge: Polity Press.

Heritage, J. and Maynard, D.W. (2006) Problems and prospects in the study of physicianpatient interaction: 30 years of research, Annual Review of Sociology. 32,351-74.

Hillman, A. (2007) Negotiating access: Practices of inclusion and exclusion in the performance of 'real' emergency medicine. Ph.D. Cardiff University.

Hjort, P. (2006) Helsetjenesten mot år 2030 - tanker om utfordringene, Tidsskrift for Den norske legeforening. 126,32-6. 
Hogle, L.F. (1995) Standardization across non-standard domains: the case of organ procurement, Science, Technology, \& Human Values. 20, 4, 482-500.

Howe, D. (1991) Knowledge, power and the shape of social work practice. In Davies, M. (ed.) The Sociology of Social Work. London: Routledge.

Hoyle, L. (2014) 'I mean, obviously you're using your discretion': Nurses Use of Discretion in Policy Implementation, Social Policy and Society. 13, 02, 189-202.

Hughes, D. (1977) Everyday and medical knowledge in categorizing patients. In Dingwall, R., Heath, C., Reid, M., and Stacey, M. (eds.) Health Care and Health Knowledge. London: Croom Helm. pp. 128-40.

Hunter, D.J. (1996) Rationing and evidence-based medicine, Journal of Evaluation in Clinical Practice. 2, 1, 5-8.

Hupe, P. and Hill, M. (2007) Street-level bureaucracy and public accountability, Public Administration. 85, 2, 279-99.

Hupe, P., Hill, M. and Buffat, A. (2015) Understanding street-level bureaucracy. Bristol: Policy Press.

Iserson, K.V. and Moskop, J.C. (2007) Triage in medicine, part I: Concept, history, and types, Annals of Emergency Medicine. 49, 3, 275-81.

Järvinen, M. and Mik-Meyer, N. (2017) Kvalitativ analyse: syv traditioner. København: Hans Reitzel.

Jeffery, R. (1979) Normal rubbish: deviant patients in casualty departments, Sociology of Health \& Illness. 1,90-107.

Jerolmack, C. and Khan, S. (2014) Talk is cheap: ethnography and the attitudinal fallacy, Sociological Methods \& Research. 43, 2, 178-209.

Johannessen, L.E.F. (2013) 'Det er ikke undere vi driver med' - Betydningen av hjernehinneblødningens fortelling for sykdommens og nevrokirurgiens prestisje. Mastergrad. Oslo: Universitetet i Oslo.

Johannessen, L.E.F. (2016) How triage nurses use discretion: A literature review, Professions and Professionalism. 5, 3.

Jones, C., Exworthy, M. and Halford, S. (1999) Social work: Regulation and managerialism. In Professionals and the New Managerialism in the Public Sector. Buckingham: Open University Press.

Jordan, K. and Lynch, M. (1998) The dissemination, standardization and routinization of a molecular biological technique, Social Studies of Science. 28, 5-6, 773-800. 
Kalleberg, R., Engelstad, F. and Malnes, R. (2009) Samfunnsvitenskapenes oppgaver, arbeidsmåter og grunnlagsproblemer. Oslo: Gyldendal akademisk.

Keiser, L.R. (2010) Understanding street-level bureaucrats’ decision making: determining eligibility in the social security disability program, Public Administration Review. 70, 2, 247-57.

Khan, S. and Jerolmack, C. (2013) Saying meritocracy and doing privilege, The Sociological Quarterly. 54, 1, 9-19.

Knaapen, L. (2014) Evidence-based medicine or cookbook medicine? Addressing concerns over the standardization of care, Sociology Compass. 8, 6, 823-36.

Kövecses, Z. (2006) Language, mind, and culture: a practical introduction. Oxford University Press. New York: Oxford University Press.

Lamont, M. (1994) Money, morals, and manners: the culture of the French and the American upper-middle class. 1 edition. Chicago: University Of Chicago Press.

Lamont, M. (2009) How professors think: inside the curious world of academic judgment. Cambridge, Mass: Harvard University Press.

Lamont, M. and Molnár, V. (2002) The study of boundaries in the social sciences, Annual Review of Sociology. 28,167-95.

Lamont, M. and Swidler, A. (2014) Methodological pluralism and the possibilities and limits of interviewing, Qualitative Sociology. 37, 2, 153-71.

Lampland, M. and Star, S.L. (2009) Standards and their stories: how quantifying, classifying, and formalizing practices shape everyday life. Ithaca, N.Y.: Cornell University Press.

Latour, B. and Woolgar, S. (1986) Laboratory life: the construction of scientific facts. New Jersey: Princeton University Press.

Leder, D. (1990) Clinical interpretation: The hermeneutics of medicine, Theoretical Medicine. 11,9-24.

Levin, S., Toerper, M., Hamrock, E., Hinson, J.S., et al. (2017) Machine-learning-based electronic triage more accurately differentiates patients with respect to clinical outcomes compared with the Emergency Severity Index, Annals of Emergency Medicine.

Liodden, T. (2017) The burdens of discretion. Managing uncertainty in the asylum bureaucracy. Ph.D. Universitetet i Oslo.

Lipsky, M. (1971) Street-level bureaucracy and the analysis of urban reform, Urban Affairs Quarterly. 6, 4, 391-409. 
Lipsky, M. (1980) Street-level bureaucracy: dilemmas of the individual in public services. New York: Russell Sage Foundation.

Lipsky, M. (2010) Street-level bureaucracy: dilemmas of the individual in public services. 30th anniversary expanded ed. New York: Russell Sage Foundation.

Lund, E.C. (2012) Virke og profesjon. Oslo: Akribe.

Lymbery, M. (1998) Care management and professional autonomy: the impact of community care legislation on social work with older people, The British Journal of Social Work. 28, 6, 863-78.

Lymbery, M. (2000) The retreat from professionalism, Professionalism, boundaries and the workplace. 123-38.

Lynch, M. (2018) The narrative of the number: quantification in criminal court, Law \& Social Inquiry. $\mathrm{n} / \mathrm{a}-\mathrm{n} / \mathrm{a}$.

Van Maanen, J. (2011) Tales of the field: on writing ethnography. Chicago: The University of Chicago Press.

MacDonald-Nethercott, E., Richter, S., Boyle, A. and Higginson, I. (2016) What should be done to reduce emergency department crowding? - a delphi study, Emergency Medicine Journal. 33, 12, 914-914.

Mackway-Jones, K., Marsden, J., Windle, J. and Manchester Triage Group (2014) Emergency triage. 3rd ed. Chichester: Wiley.

Malinowski, B. (1922) Argonauts of the Western Pacific: an account of native enterprise and adventure in the archipelagoes of Melanesian New Guinea. Long grove, Il.: Waveland Press, Inc.

Manchester Triage Group (2011) Akuttmedisinsk triage. Oslo: Unipub.

Manchester Triage Group (2015) Akuttmedisinsk triage. 2. utg. Oslo: Gyldendal akademisk.

Marx, K. (1867) Capital, Volume One. New York: Vintage books.

Mattingly, C. (1998) In search of the good: narrative reasoning in clinical practice, Medical Anthropology Quarterly. 12, 3, 273-97.

May, P.J. and Winter, S.C. (2009) Politicians, managers, and street-level bureaucrats: influences on policy implementation, Journal of Public Administration Research and Theory. 19, 3, 453-76. 
Maynard-Moody, S. and Musheno, M. (2012) Social equities and inequities in practice: streetlevel workers as agents and pragmatists, Public Administration Review. 72, s1, S16S23.

Maynard-Moody, S. and Musheno, M.C. (2003) Cops, teachers, counselors: stories from the front lines of public service. First edition edition. Ann Arbor: University of Michigan Press.

Maynard-Moody, S. and Portillo, S. (2010) Street-level bureaucracy theory. In Durant, R.F. and Edwards III, G.C. (eds.) The Oxford Handbook of American Bureaucracy. Oxford: Oxford University Press. pp. 252-77.

Meyers, M.K. and Lehmann Nielsen, V. (2012) Street-level bureaucracy and public policy. In Guy Peters, B. and Pierre, J. (eds.) The SAGE Handbook of Public Administration. London: SAGE. pp. 305-18.

Mik-Meyer, N. (2017) The power of citizens and professionals in welfare encounters: the influence of bureaucracy, market and psychology. Social and Political Power MUP Series. Oxford: Manchester University Press.

Mintzberg, H. (1979) The structuring of organizations: a synthesis of the research. Englewood Cliffs, N.J: Prentice-Hall.

Mintzberg, H. (2005) Developing theory about the development of theory, Great minds in management: The process of theory development. 355-72.

Mitchell, T.M. (1997) Machine learning. New York, NY: McGraw-Hill Education.

Molander, A. (2016) Discretion in the welfare state: social rights and professional judgment. Abingdon, Oxon ; New York, NY: Routledge.

Mykhalovskiy, E. and Weir, L. (2004) The problem of evidence-based medicine: directions for social science, Social Science \& Medicine. 59, 5, 1059-69.

Neyland, D. (2008) Organizational ethnography. Los Angeles: SAGE Publications.

Norwegian Board of Health Supervision (2008) 'Mens vi venter...'-forsvarlig pasientbehandling i akuttmottakene?

NOU (2014) Åpent og rettferdig - prioriteringer i helsetjenesten.

NOU (2015) Først og fremst — Et helhetlig system for håndtering av akutte sykdommer og skader utenfor sykehus.

O’Cathain, A., Sampson, F.C., Munro, J.F., Thomas, K.J., et al. (2004) Nurses’ views of using computerized decision support software in NHS Direct, Journal of Advanced Nursing. 45, 3, 280-6. 
Padgett, S.M. (2013) Professional collegiality and peer monitoring among nursing staff: An ethnographic study, International journal of nursing studies. 50, 10, 1407-15.

Pines, J.M., Hilton, J.A., Weber, E.J., Alkemade, A.J., et al. (2011) International perspectives on emergency department crowding, Academic Emergency Medicine: Official Journal of the Society for Academic Emergency Medicine. 18, 12, 1358-70.

Polanyi, M. (1967) The tacit dimension. Garden City: Doubleday.

Prottas, J.M. (1979) People-processing: the street-level bureaucrat in public service bureaucracies. Lexington, Mass: Lexington Books.

Raknes, G. and Hunskaar, S. (2017) Reasons for encounter by different levels of urgency in out-of-hours emergency primary health care in Norway: a cross sectional study, BMC Emergency Medicine. 17,19.

Rapley, T. (2008) Distributed decision making: the anatomy of decisions-in-action, Sociology of Health \& Illness. 30, 3, 429-44.

Reed, I. (2008) Justifying sociological knowledge: from realism to interpretation, Sociological Theory. 26, 2, 101-29.

Ringard, Å., Sagan, A., Saunes, I.S. and Lindahl, A.K. (2013) Norway - Health system review, Health System in Transition. 15, 8, 1-162.

Ritzer, G. (1993) The McDonaldization of society: an investigation into the changing character of contemporary social life. 9 edition. Thousand Oaks, California: Pine Forge Press.

Rock, P. (2001) Symbolic interactionism and ethnography. In Atkinson, P., Coffey, A., Delamont, S., Lofland, J., et al. (eds.) Handbook of Ethnography. SAGE Publications Ltd. pp. 26-39.

Rosoff, A.J. (2001) Evidence-based medicine and the law: the courts confront clinical practice guidelines, Journal of Health Politics, Policy and Law. 26, 2, 327-68.

Roth, J.A. (1971) Utilization of the hospital emergency department, Journal of Health and Social Behavior. 12, 4, 312-20.

Roth, J.A. (1972) Some contingencies of the moral evaluation and control of clientele: The case of the hospital emergency service, American Journal of Sociology. 77, 5, 839-56.

Russell, B. (2012) Professional call centres, professional workers and the paradox of the algorithm: the case of telenursing, Work, Employment \& Society. 26, 2, 195-210.

Ruston, A. (2006) Interpreting and managing risk in a machine bureaucracy: Professional decision-making in NHS Direct, Health, Risk \& Society. 8, 3, 257-71. 
Sandvik, H., Hunskår, S. and Diaz, E. (2012) Fastlegepasienters bruk av legevakt, Tidsskrift for Den norske legeforening. 132, 20, 2272-6.

Schmidt, V.H. (2004) Models of health care rationing, Current Sociology. 52, 6, 969-88.

Schutz, A. (1953) Common-sense and scientific interpretation of human action, Philosophy and Phenomenological Research. 14, 1, 1-38.

Schutz, A. (1967) Phenomenology of the social world. 1 edition. Evanston, Ill.: Northwestern University Press.

Schwandt, T. (1994) Constructivist, interpretivist approaches to human inquiry. In Denzin, N.K. and Lincoln, Y. (eds.) The landscape of qualitative research: Theories and issues. pp. 221-59.

Seale, C. (1999) The quality of qualitative research. London: Sage.

Shapiro, S. (1997) Degrees of freedom: the interaction of standards of practice and engineering judgment, Science, Technology, \& Human Values. 22, 3, 286-316.

Smith, S. (2012) Street-level bureaucracy and public policy. In Guy Peters, B. and Pierre, J. (eds.) The SAGE Handbook of Public Administration. London: SAGE. pp. 431-46.

Spradley, J.P. (1979) The ethnographic interview. New York: Holt, Rinehart and Winston.

Spradley, J.P. (1980) Participant observation. 1st edition. New York: Holt, Rinehart and Winston.

SSB (n.d.) 07938: Personer med helse- og sosialfaglig utdanning, etter kjønn og alder. 4. kvartal 2008 - 2017. [Online].

Stilgoe, J. (2018) Machine learning, social learning and the governance of self-driving cars, Social Studies of Science. 48, 1, 0306312717741687.

Strauss, A., Schatzman, L., Ehrlich, D., Bucher, R., et al. (1963) The hospital and it's negotiated order. In Freidson, E. (ed.) The hospital in modern society. New York: Free Press.

Sudnow, D. (1967) Passing on: the social organization of dying. Englewood Cliffs, N.J.: Prentice-Hall.

Swedberg, R. (2017) Theorizing in sociological research: a new perspective, a new departure?, Annual Review of Sociology. 43, 1, 189-206.

Sykepleien (2009) - Respektløst begrep, Sykepleien. 97, 7.

Taylor, I. (2007) Discretion and control in education: the teacher as street-level bureaucrat, Educational Management Administration \& Leadership. 35, 4, 555-72. 
The National Centre for Emergency Primary Health Care (2009) ...er hjelpa ncermast! Forslag til Nasjonal handlingsplan for legevakt. [Online]. Nasjonalt kompetansesenter for legevaktmedisin, Unifob helse.

The National Centre for Emergency Primary Health Care (2014) Nasjonale krav til legevakt og fremtidens øyeblikkelig hjelp-tilbud i kommunene. Oppdrag fra Akuttutvalget. [Online]. Nasjonalt kompetansesenter for legevaktmedisin, Uni Research Helse.

The Norwegian Medical Association (2015) En legevakt for alle, men ikke for alt. Legeforeningens innspillsrapport for en bedre legevakt.

Thompson, G.A. (2014) Labeling in interactional practice: applying labeling theory to interactions and interactional analysis to labeling, Symbolic Interaction. 37, 4, 458-82.

Timmermans, S. (1999) When death isn't dead: implicit social rationing during resuscitative efforts, Sociological Inquiry. 69, 1, 51-75.

Timmermans, S. (2005) From autonomy to accountability: the role of clinical practice guidelines in professional power, Perspectives in Biology and Medicine. 48, 4, 490501.

Timmermans, S. and Berg, M. (1997) Standardization in action: achieving local universality through medical protocols, Social Studies of Science. 27, 2, 273-305.

Timmermans, S. and Berg, M. (2003) The gold standard: the challenge of evidence-based medicine and standardization in health care. Philadelphia, Pa: Temple University Press.

Timmermans, S. and Epstein, S. (2010) A world of standards but not a standard world: Toward a sociology of standards and standardization, Annual Review of Sociology. 36, 1, 69-89.

Tjora, A. (2000) The technological mediation of the nursing-medical boundary, Sociology of Health \& Illness. 22, 6, 721-41.

Tolich, M. (2004) Internal confidentiality: When confidentiality assurances fail relational informants, Qualitative Sociology. 27, 1, 101-6.

Turco, C.J. and Zuckerman, E.W. (2017) Verstehen for sociology: comment on Watts, American Journal of Sociology. 122, 4, 1272-91.

Ubel, P.A. and Goold, S. (1997) Recognizing bedside rationing: clear cases and tough calls, Annals of Internal Medicine. 126,74-80.

Ugelvik, T. (2014) Prison ethnography as lived experience: notes from the diaries of a beginner let loose in Oslo prison, Qualitative Inquiry. 20, 4, 471-80. 
Vassy, C. (2014) Emergency departments. In Cockerham, W., Dingwall, R., and Quah, S. (eds.) The Wiley Blackwell Encyclopedia of Health, Illness, Behavior, and Society. Chichester: Wiley-Blackwell.

Venkatesh, S. (2002) `Doin’ the hustle’: constructing the ethnographer in the American ghetto, Ethnography. 3, 1, 91-111.

Vergne, J.-P. and Wry, T. (2014) Categorizing categorization research: review, integration, and future Directions, Journal of Management Studies. 51, 1, 56-94.

Wadel, C. (1973) Now, whose fault is that?: the struggle for self-esteem in the face of chronic unemployment. St. John's, Nfld.: Institute of Social and Economic Research, Memorial University of Newfoundland.

Wadel, C. (1991) Feltarbeid i egen kultur: en innføring i kvalitativt orientert samfunnsforskning. Flekkefjord: SEEK.

Wahlberg, A.C., Cedersund, E. and Wredling, R. (2003) Telephone nurses' experience of problems with telephone advice in Sweden, Journal of Clinical Nursing. 12, 1, 37-45.

Walby, S. and Greenwell, J. (1994) Medicine and nursing: professions in a changing health service. London: Sage.

Walker, L. and Gilson, L. (2004) 'We are bitter but we are satisfied': nurses as street-level bureaucrats in South Africa, Social Science \& Medicine. 59, 6, 1251-61.

Weber, M. (1930) The Protestant ethic and the spirit of capitalism. Unwin University books. London: Unwin University Books.

Weber, M. (1978) Economy and society: an outline of interpretive sociology. Berkeley, Calif.: University of California Press.

Weber, M. (1983) General economic history. New Brunswick, N.J.: Transaction Publishers.

Weiss, M.C. (2011) Diagnostic decision making: The last refuge for general practitioners?, Social Science \& Medicine. 73, 3, 375-82.

Weiss, R.S. (1994) Learning from strangers : the art and method of qualitative interview studies. New York: Free Press.

Weisz, G., Cambrosio, A., Keating, P., Knaapen, L., et al. (2007) The Emergence of Clinical Practice Guidelines, Milbank Quarterly. 85, 4, 691-727.

Whyte, W.F. (1993) Street corner society: the social structure of an Italian slum. Chicago: University of Chicago Press. 
Wilkinson, C. and MacLean, S. (2013) Enforcement of liquor licence provisions: The introduction of civilian licence inspectors in Victoria, Drugs: Education, Prevention and Policy. 20, 1, 15-21.

Wittgenstein, L. (1953) Philosophical investigations. Oxford: Basil Blackwell.

Wolcott, H.F. (1994) Description, analysis, and interpretation in qualitative inquiry. In Wolcott, H.F. (ed.) Transforming Qualitative Data. Description, Analysis, Interpretation. Thousand Oaks, Calif.: SAGE. pp. 9-54.

Wolcott, L.B.W. (1979) What is an emergency? Depends on whom you ask, Journal of the American College of Emergency Physicians. 8, 6, 241-3.

Zerubavel, E. (1991) The fine line: making distinctions in everyday life. New York, N.Y.: Free Press.

Zerubavel, E. (1996) Lumping and splitting: notes on social classification, Sociological Forum. 11, 3, 421-33.

Zerubavel, E. (1997) Social mindscapes: an invitation to cognitive sociology. Cambridge, Mass.: Harvard University Press. 


\section{Appendices}

1: Excerpt from the MTS manual: Flow chart with discriminators

36

15 Dårlig voksen

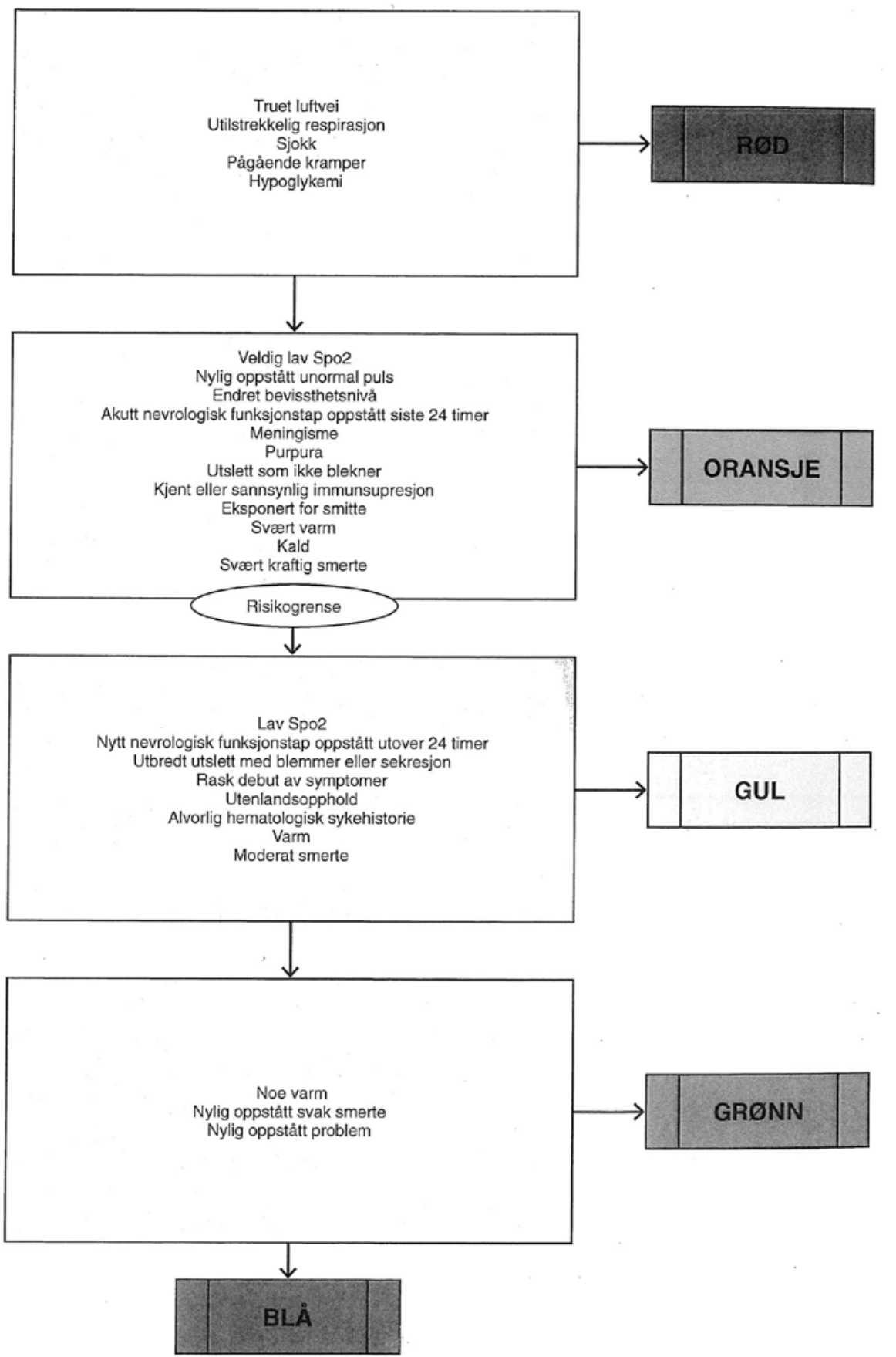

Reprinted with permission from the Norwegian Manchester Triage Group. 


\section{2: Excerpt from the MTS manual: Specification of discriminators}

Kommentarer til Dårlig voksen

\begin{tabular}{|c|c|}
\hline Se også & Kommentarer \\
\hline Illebefinnende & $\begin{array}{l}\text { De spesifikke diskriminatorerene skal sikre indentifisering av alvorlige sykdomstilstander som for } \\
\text { eksempel meningokokksepsis. }\end{array}$ \\
\hline $\begin{array}{l}\text { Generelle og spesifikke } \\
\text { diskriminatorer }\end{array}$ & Forklaring \\
\hline Truet luftvei & $\begin{array}{l}\text { En luftvei kan være truet enten fordi den ikke kan holdes åpen, eller fordi luftveisbeskyttende } \\
\text { reflekser (som stopper inhalasjon) er tapt. Dette vil føre til intermitterende total eller delvis } \\
\text { obstruksjon. Dette manifesterer seg som snorkelyder eller boblende lyder ved respirasjon. }\end{array}$ \\
\hline Utilstrekkelig respirasjon & $\begin{array}{l}\text { Pasienter som ikke er i stand til ả puste godt nok til å opprettholde tilstrekkelig oksygenering har } \\
\text { utilstrekkelig respirasjon. Man kan se anstrengt respirasjon eller utmattelse. }\end{array}$ \\
\hline Sjokk & $\begin{array}{l}\text { Sjokk er utilstrekkelig oksygentilførsel til vevet. De klassiske tegnene inkluderer svette, blekhet, } \\
\text { takykardi, hypotensjon og redusert bevissthetsnivå. }\end{array}$ \\
\hline Pågâende kramper & Pasienter som er i generalisert tonisk eller klonisk anfall, og pasienter som har partielle kramper. \\
\hline Hypoglykemi & Glukose lavere enn $3 \mathrm{mmol} / \mathrm{h}$ \\
\hline Veldig lav Spo2 & Saturasjon lavere enn 95 \% med O2-behandling, eller lavere enn 92 \% på romluft. \\
\hline Nylig oppstått unormal puls & $\begin{array}{l}\text { Bradykardi (under } 60 \text { slag per min hos voksne), takykardi (over100 slag per min hos voksne) eller } \\
\text { en uregelmessig rytme som har oppstått i løpet av de siste } 7 \text { dager. Aldersspesifikke referanse- } \\
\text { omrăder av bradykardi og takykardi bør brukes hos barn. }\end{array}$ \\
\hline Endret bevissthetsnivå & $\begin{array}{l}\text { En pasient som ikke er helt klar. Responderer enten bare på tilsnakk eller smerte, eller } \\
\text { responderer ikke. }\end{array}$ \\
\hline $\begin{array}{l}\text { Akutt nevrologisk } \\
\text { funksjonstap oppstått siste } \\
24 \text { timer }\end{array}$ & $\begin{array}{l}\text { Ethvert tap av nevrologisk funksjon som har debutert siste } 24 \text { timer. Dette kan inkludere endret eller } \\
\text { tapt sensibilitet/sanseopplevelse, svakhet i ekstremiteter (enten forbigảende eller permanent) og } \\
\text { forstyrrelser i blære- eller tarmfunksjon. }\end{array}$ \\
\hline Meningisme & Klassisk er stiv nakke sammen med hodepine og lysskyhet. \\
\hline Purpura & $\begin{array}{l}\text { Et utslett hvor som helst på kroppen som har sammenheng med små blødninger under huden. } \\
\text { Purpura blekner ikke (blir ikke hvitt) når det utøves trykk mot det. }\end{array}$ \\
\hline Utslett som ikke blekner & $\begin{array}{l}\text { Utslett som ikke blekner (blir hvitt) når det utøves trykk mot det. Blir ofte testet ved å bruke et glass } \\
\text { slik at fargeforandringer kan observeres gjennom bunnen pả glasset. }\end{array}$ \\
\hline $\begin{array}{l}\text { Kjent eller sannsynlig } \\
\text { immunsuppresjon }\end{array}$ & $\begin{array}{l}\text { Enhver pasient som er kjent eller sannsynlig immunsupprimert, inkludert de som går på } \\
\text { immunosuppressive medisiner (for eksempel langvarig bruk av steroider). }\end{array}$ \\
\hline Eksponert for smitte & $\begin{array}{l}\text { Kjent eksponering for et farlig patogen, eller reise til et omrảde med en identifisert, alvorlig } \\
\text { infeksjonsrisiko. }\end{array}$ \\
\hline Svært varm & $\begin{array}{l}\text { Hvis huden kjennes svært varm, sies pasienten klinisk â være svært varm. Mâl temperaturen } \\
\text { sả snart som mulig - en temperatur høyere enn } 41^{\circ} \mathrm{C} \text { er svært varm. }\end{array}$ \\
\hline Kald & $\begin{array}{l}\text { Pasienten er kald hvis huden kjennes kald. Temperaturen bør måles så raskt som mulig - en } \\
\text { kjernetemperatur lavere enn } 35^{\circ} \mathrm{C} \text { er kald. }\end{array}$ \\
\hline Svært kraftig smerte & $\begin{array}{l}\text { Uutholdelige smerter - ofte beskrevet som den sterkeste noensinne. Bruk smertestigen. (Se kapittel } \\
\text { om smertevurdering). }\end{array}$ \\
\hline Lav Spo2 & Dette er en saturasjon lavere enn $95 \%$ pả romluft. \\
\hline $\begin{array}{l}\text { Nytt nevrologisk funksjons- } \\
\text { tap oppstătt utover } 24 \text { timer }\end{array}$ & $\begin{array}{l}\text { Ethvert tap av nevrologisk funksjon som har debutert utover } 24 \text { timer. Dette kan inkludere endret } \\
\text { eller tapt sensibilitet/sanseopplevelse, svakhet iekstremiteter (forbigáende eller permanent) og } \\
\text { forstyrrelser i blære- eller tarmfunksjon. }\end{array}$ \\
\hline $\begin{array}{l}\text { Utbredt utslett med } \\
\text { blemmer eller sekresjon }\end{array}$ & $\begin{array}{l}\text { Enhver form for utbrudd som væsker eller gir blemmer, og som dekker mer en } 10 \% \text { av kropps- } \\
\text { overflaten. }\end{array}$ \\
\hline Rask debut av symptomer & Debut i løpet av de siste 12 timene. \\
\hline Utenlandsopphold & Nylig vært på utenlandsreise eller -opphold i eksotiske strøk (siste 2 uker). \\
\hline $\begin{array}{l}\text { Alvorlig hematologisk } \\
\text { sykehistorie }\end{array}$ & En pasient med hematologisk sykdom som er kjent for å forverres raskt. \\
\hline Varm & $\begin{array}{l}\text { Hvis huden kjennes varm sies man klinisk å være varm. Mål temperaturen så snart som mulig } \\
\text { - en temperatur over } 38,5^{\circ} \mathrm{C} \text { er varm. }\end{array}$ \\
\hline Moderat smerte & Smerte som er intens, men til ả holde ut. Bruk smertestigen. (Se kapitlet om smertevurdering). \\
\hline Noe varm & $\begin{array}{l}\text { Hvis huden kjennes noe varm, sies pasienten klinisk å være noe varm. Temperaturen bør måles } \\
\text { sả snart som mulig - en temperatur høyere enn } 37,5^{\circ} \mathrm{C} \text { er noe varm. }\end{array}$ \\
\hline Nylig oppstátt svak smerte & $\begin{array}{l}\text { Smerte som har oppstått i løpet av de siste } 7 \text { dager. Bruk smertestigen. (Se kapitlet om smerte- } \\
\text { vurdering). }\end{array}$ \\
\hline Nylig oppstâtt problem & Et problem som har oppstått i løpet av de siste 7 dager. \\
\hline
\end{tabular}




\section{3: Ethics approval}

\section{Norsk samfunnsvitenskapelig datatjeneste AS}

NORWEGIAN SOCIAL SCIENCE DATA SERVICES

Lars Emil Fagernes Johannessen

Senter for profesjonsstudier Høgskolen i Oslo og Akershus

Postboks 4 St. Olavs plass

0130 OSLO

Vår dato: 17.03 .2015

Vår ref: 42085 / 3 / AGL

Deres dato:

Deres ref:

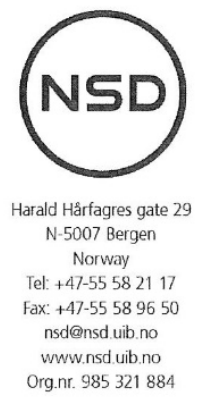

TILBAKEMELDING PA MELDING OM BEHANDLING AV PERSONOPPLYSNINGER

Vi viser til melding om behandling av personopplysninger, mottatt 05.02.2015. All nødvendig informasjon om prosjektet forelå i sin helhet 04.03.2015. Meldingen gjelder prosjektet:
42085
Fortolkning og prioritering av pasienter på legevakten
Behandlingsansvarlig
Høgskolen i Oslo og Akershus, ved institusjonens øverste leder
Daglig ansvarlig
Lars Emil Fagernes Johannessen

Personvernombudet har vurdert prosjektet og finner at behandlingen av personopplysninger er meldepliktig i henhold til personopplysningsloven § 31 . Behandlingen tilfredsstiller kravene i personopplysningsloven.

Personvernombudets vurdering forutsetter at prosjektet gjennomføres i tråd med opplysningene gitt i meldeskjemaet, korrespondanse med ombudet, ombudets kommentarer samt personopplysningsloven og helseregisterloven med forskrifter. Behandlingen av personopplysninger kan settes i gang.

Det gjøres oppmerksom på at det skal gis ny melding dersom behandlingen endres i forhold til de opplysninger som ligger til grunn for personvernombudets vurdering. Endringsmeldinger gis via et eget skjema, http://www.nsd.uib.no/personvern/meldeplikt/skjema.html. Det skal også gis melding etter tre år dersom prosjektet fortsatt pågår. Meldinger skal skje skriftlig til ombudet.

Personvernombudet har lagt ut opplysninger om prosjektet i en offentlig database, http://pvo.nsd.no/prosjekt.

Personvernombudet vil ved prosjektets avslutning, 01.01.2019, rette en henvendelse angående status for behandlingen av personopplysninger.

Vennlig hilsen

Katrine Utaaker Segadal

Audun Løvlie

Kontaktperson: Audun Løvlie tlf: 55582307

Vedlegg: Prosjektvurdering

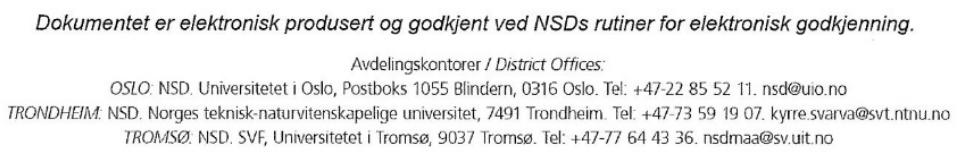




\title{
4: Information letter / informed consent form
}

\author{
Fortolkning og beslutningstaking på legevakten \\ Forespørsel om deltakelse i et doktorgradsprosjekt av Lars E.F. Johannessen, HiOA
}

Hva innebærer prosjektet?

Doktorgradsprosjektet er en sosiologisk studie av hvordan legevaktansatte fortolker og fatter beslutninger om pasienter. Jeg vil blant annet undersøke prosedyrene, hjelpemidlene og kunnskapen dere benytter i deres arbeid, samt hvordan arbeidet er fordelt på legevaktens ulike posisjoner. Prosjektet har til hensikt å øke kunnskapen om hvordan legevaktansatte klarer å prioritere innad i en stor, uavklart og uselektert pasientgruppe, med det formål å bidra til forståelse for og forbedring av legevaktens pasientbehandling.

Jeg er sosiolog, ikke helsearbeider. Prosjektet vil derfor beskrive, ikke vurdere, det arbeid dere giør. $\AA$ vurdere arbeidet er noe jeg verken er kompetent til eller interessert i. Det er også verdt å merke seg at prosjektet dreier seg om dere ansatte, ikke pasienter. Derfor vil jeg ikke nedtegne verken direkte eller indirekte personidentifiserbare opplysninger om pasientene.

Prosjektet er basert på kvalitative forskningsmetoder. Jeg vil særlig benytte såkalt deltakende observasjon, som her innebærer å følge dere rundt på legevakten, observere det arbeid dere gjør, og snakke med dere om deres arbeidshverdag. Etter hvert er jeg også interessert i å spørre enkelte av dere om dere vil delta i intervjuer. Datainnsamlingen vil foregå over en periode på ca. seks måneder, der jeg deltar på arbeidsøkter ca. to til fem ganger i uken. Prosjektet er tilknyttet Senter for profesjonsstudier ved Høgskolen i Oslo og Akershus.

Hva skjer med opplysningene du gir fra deg?

Informasjonen som registreres skal kun brukes som beskrevet i hensikten med studien. All informasjon som nedtegnes vil bli behandlet uten navn eller andre direkte gjenkjennende opplysninger. Jeg er underlagt taushetsplikt. Alle opplysninger vil bli behandlet konfidensielt, og ingen enkeltpersoner skal kunne gjenkjennes i den endelige studien.

Som deltaker i studien har du rett til å få innsyn i hvilke opplysninger jeg registrerer om deg. Du har også rett til å få korrigert eventuelle feil i de opplysningene jeg har registrert. Deltakelse i studien er frivillig. Du kan når som helst og uten begrunnelse trekke deg fra studien. Dersom du trekker deg kan du kreve å få slettet innsamlede opplysninger, med mindre de allerede er inngått $\mathrm{i}$ analyser eller brukt $\mathrm{i}$ vitenskapelige publikasjoner. Alle som deltar i studien har rett til å få informasjon om resultatene av den. Prosjektet vil avsluttes innen 1. januar 2019. Alle personsensitive data vil da bli slettet. Studien er meldt til personvernombudet for forskning, Norsk samfunnsvitenskapelig datatjeneste AS. I tillegg er den behandlet i Regional komité for medisinsk og helsefaglig forskningsetikk. Høgskolen i Oslo og Akershus ved administrerende direktør er databehandlingsansvarlig.

Lurer du på noe mer?

Du kan kontakte meg på tlf. 48293782 eller epost lars.johannessen@hioa.no.

\section{SAMTYKKEERKLÆERING}

Jeg har lest og forstått informasjonen over og samtykker til å delta i studien

Sted og dato Signatur





\section{Article 1}

Johannessen, L.E.F. (2017). Beyond guidelines: Discretionary practice in face-toface triage nursing. Sociology of Health \& Illness 39(7): 1180-1194. 



\title{
Beyond guidelines: discretionary practice in face-to-face triage nursing
}

\section{Lars E.F. Johannessen}

\author{
Centre for the Study of Professions, Oslo and Akershus University College of Applied \\ Sciences, Norway
}

\begin{abstract}
This article draws on ethnographic data from a Norwegian emergency primary care clinic (EPCC) to explore nurses' discretionary application of guidelines.

Specifically, it analyses nurses' discretionary use of the Manchester Triage System (MTS) when performing face-to-face triage, that is, assessing the urgency of patients' complaints. The analysis shows how nurses assessed patients at odds with MTS prescriptions by collecting supplementary data, engaging in differential diagnostic and holistic reasoning, relying on emotion and intuition, and allowing colleagues and patients to influence their reasoning. The findings also show how nurses' reasoning led them to override guidelines both overtly and covertly. Based on this evidence, it is argued that nurses' assessments relied more on internalised 'triage mindlines' than on codified triage guidelines, although the MTS did function as a support system, checklist and system for supervisory control. The study complements existing research on standardisation in nursing by providing an in-depth analysis of nurses' methods for navigating guidelines and by detailing how deviations from those guidelines spring from their clinical reasoning. The challenges of imposing a managerial logic on professional labour are also highlighted, which is of particular relevance in light of the drive towards standardisation in modern healthcare.
\end{abstract}

Keywords: triage, discretion, nursing, standardisation, guidelines, mindlines

\section{Introduction}

From the 1980s onward, standardisation has been 'a focal point of interest in the health care field' (Timmermans and Berg 2003: 13). A key expression of this interest is the continual introduction of what are variously called guidelines, protocols, algorithms or standards, which have in common that they constitute 'a set of instructions telling medical personnel to do A in situation B' (Berg 1997: 1081). Timmermans and Berg (2003: 26) characterise these as 'procedural standards' and claim that they 'boost the stakes of standardization to the highest level' because they 'attempt to achieve the seemingly impossible: prescribe the behavior of professionals'.

Procedural standards have become remarkably widespread in emergency medical service (EMS) triage, in which healthcare workers - typically nurses - assess the urgency of patients' complaints in order to determine how long they can wait before receiving medical attention (FitzGerald et al. 2010). In Norway, attempts to standardise triage multiplied in the wake of a 
highly critical report from the Norwegian Board of Health Supervision (2008), to which managers responded by introducing guidelines to ensure more systematic and objective assessments (Halvorsen et al. 2014).

Despite managerial intentions, however, standardisation research suggests that the influence of guidelines varies. Ethnomethodologists have noted that no rule can exhaustively prescribe every aspect of a practice (cf. Heritage 1984), and empirical analyses have shown how workers can tinker with standards in a number of ways (cf. Timmermans and Epstein 2010).

The aim of this article is to explore nurses' discretionary use of guidelines when performing face-to-face triage - a type of triage that has received markedly little attention in the guideline application literature. Specifically, the article analyses how nurses use discretion in their clinical reasoning and priority setting. Clinical reasoning refers to the social process of making judgments about patients' state of health, which despite its centrality in understanding guideline application has been under-analysed in previous guideline research.

The data are drawn from an ethnographic project in an urban, large-scale emergency primary care clinic (EPCC), ${ }^{1}$ which resembles EMS organisations in several other countries in that it is open to all patients at all times. The EPCC in question utilised the Manchester Triage System (MTS), which is Europe's most widely used triage guideline (Mackway-Jones et al. 2014).

The analysis shows how nurses contravened MTS recommendations by collecting supplementary data, engaging in differential diagnostic and holistic reasoning, relying on emotion and intuition and being influenced by interaction with colleagues, patients or patients' relatives. The findings also show that nurses would override the system by both overt and covert methods whenever their discretionary assessments led them to believe that the system-prescribed waiting time was unreasonable or unrealistic. Based on these findings, it is argued that nurses relied more on 'triage mindlines' than on MTS guidelines when assessing patients, although the guidelines did function as a support system, checklist and system for supervisory control.

In what follows, I review the research on standardisation and triage, provide an overview of the present study's data and methods, and present and discuss its findings.

\section{Standardisation and triage}

Medical sociology has a strong tradition of examining the effects of managerialism and managerial tools on the autonomy of healthcare professionals (cf. Berg et al. 2000, Germov 2005, Kirkpatrick et al. 2009, Light and Levine 1988, Numerato et al. 2012, Sheaff et al. 2003, Timmermans and Berg 1997, 2003). This section will concentrate mainly on the small but significant literature investigating the ways in which triage nurses (do not) use guidelines. These studies have focused almost exclusively on call-centres, and in particular on the use of the computer-based Clinical Assessment System (CAS) in NHS Direct (the precursor to NHS $111){ }^{2}$ There is a significant body of evidence of what Lampland and Star (2009: 15) have termed the 'slippage' between standards and their practical application. For instance, Ruston (2006) argued that NHS Direct functions more like a professional bureaucracy than a machine bureaucracy (Mintzberg 1979), as nurses rely on their professional judgment rather than on guidelines when assessing callers. O'Cathain et al. (2004b) made the more moderate claim that nurses engage in 'dual triage', relying both on their own reasoning and on the guidelines provided when making decisions. Common to these and other studies is the finding that nurses take an 'active' rather than a 'passive' approach (Russell 2012) to guideline implementation by supplementing or replacing guidelines with their own professional discretion. 
In analysing triage and standardisation, one key interest is to describe overt and covert variations of 'active' approaches to guidelines. Overt approaches entail officially giving different urgency ratings and/or advice than those suggested by the guidelines (Greatbatch et al. 2005). Covert approaches escape management monitoring and take several forms. In their conversation analysis of nurse-patient interactions, Greatbatch et al. (2005: 825) found that nurses privilege their own knowledge and expertise and 'adapt, tailor, qualify and supplement the dispositions and advice recommended by CAS'. There is also evidence that nurses sometimes draw on their knowledge of the guidelines to 'manipulate' the system into agreeing with their own assessments (Dowding et al. 2009, O'Cathain et al. 2004b, Ruston 2006). Nurses have also been shown to rely on intuition (Johannessen 2016, O'Cathain et al. 2004a, Randell et al. 2009) and collegial support (Hanlon et al. 2005, O'Cathain et al. 2004a, Tjora 2000).

A second key interest of these studies is to explain why nurses deviate from guidelines, and several possible explanations have been suggested. First, 'slippage' has been attributed to nurses' status as professionals with specialised knowledge, 'mobility power' and a strong culture of autonomous decision-making (Greatbatch et al. 2005; Russell 2012). A second explanation is that nurses deviate because of organisational factors, such as having to assign patients' triage codes in light of resource situation in the ED as a whole (Bjørn and Balka 2007, Johannessen 2016). A third explanation is that guidelines' 'encoded' knowledge only partially reflects and/or is at odds with the knowledge required for performing urgency assessments (Bjørn and Balka 2007, Greatbatch et al. 2005, Hanlon et al. 2005, Ruston 2006, Tjora 2000). Studies adopting this third explanation report that nurses view guidelines as inflexible, reductionist and ill-adapted to nurses' particular settings (Dowding et al. 2009, Johannessen 2016, Murdoch et al. 2015, O'Cathain et al. 2004b); in some studies, nurses have even argued that strict adherence to guidelines might put certain patients at risk (Ruston 2006).

The reviewed studies provide detailed insights into guideline application in triage nursing, but they are not without limitations. First, as acknowledged by O'Cathain et al. (2004b), studies of telephone triage are not necessarily transferable to services where nurses have face-toface contact with patients. Second, as these studies predominantly analyse deviations, they have little to say about how guidelines do inform nurses' assessments. Third, these studies have tended to neglect one crucial reason for guideline deviation, namely the discordance between guidelines and nurses' clinical reasoning. While previous research has argued that nurses rely on their own clinical judgment and that there is an incongruence between guidelines' encoded and nurses' situated knowledge, little systematic analytical attention has been paid to how nurses' reason about patients' problems and how this reasoning informs triage code allocation. To complement the existing research, this study offers a detailed analysis of how nurses use discretion in their clinical reasoning and priority setting in face-to-face triage.

\section{Data and methods}

The article forms part of the author's larger ethnographic project exploring how Norwegian EPCC workers interpret and prioritise patients' needs. Fieldwork was conducted between April 2015 and December 2015. Data in this article are drawn from a large-scale, urban EPCC located in the city centre, performing more than 50,000 consultations per year, employing more than 100 nurses and physicians and open for 24 hours on every day of the week. The EPCC was divided into a 'frontline' (comprising a reception area, waiting room and two triage booths) and an 'inside' area (consisting of another waiting room, a work station and a series of examination rooms). Triage assessments typically lasted 4-8 minutes, during which a nurse 
would gather a brief medical history, ask about previous diseases and relevant medications, collect vital parameters (such as pulse, respiratory rate and temperature) and sometimes perform examinations (such as simple neurological assessments).

The 47 fieldwork sessions conducted at this EPCC had an average duration of approximately six hours. Of these, 20 sessions were spent observing nurses in triage and asking them about their assessments, enabling me to learn about their assessments and priority setting in close proximity to actual patients. In total, I observed 349 face-to-face assessments by two male and 14 female nurses, a majority of whom were aged between 25 and 35 years. On average, these nurses had worked in this EPCC for 3.5 years (range 1-7 years). I also spent two sessions attending mandatory courses in triage nursing. The remaining sessions provided information about the repercussions of triage assessments throughout the EPCC, serving as an analytical basis for comparison. For the purpose of analytical contrast, I conducted a further nine fieldwork sessions at two other emergency institutions. I also conducted semi-structured interviews with seven nurses, two physicians and two managers, in which triage assessments was a key theme. ${ }^{3}$ The interviews were transcribed verbatim. During the fieldwork, I scribbled keywords and near-verbatim quotes on a notepad or laptop for subsequent use in writing more elaborate field notes, yielding approximately 1,270 single-spaced pages. As all notes were written in Norwegian, I have translated the extracts included here, making minor grammatical and aesthetic adjustments.

The study was approved by the Norwegian Social Scientific Data Services. To secure informants' internal and external confidentiality (Tolich 2004), names and ages were anonymised. I signed non-disclosure agreements with the participating EPCCs and secured workers' informed consent by distributing an information letter and delivering several short presentations on the project. When interacting with patients, each EPCC worker I shadowed would ask whether it was acceptable that I witnessed their interaction.

I was interested in discretion prior to entering the field and followed up on this interest because I found that nurses regularly assessed and prioritised patients at odds with MTS prescriptions. Alternating between fieldwork and analysis, I tried to explore as many aspects as possible of triage nurses' discretionary practice. Among others things, this led me to experiment with assessing patients myself, using my own copy of the MTS manual.

During and after the fieldwork, significant parts of the analysis were done in Nvivo 10 (QSR International, Brisbane), sorting all the data into emergent broad-brush codes (Bazeley 2007). This article is based on 21 broad-brush codes of relevance to nurses' application of guidelines. After familiarising myself with this material, I ordered it into a deductive scheme of 12 codes, the most central of which were 'deviations from MTS', 'MTS restrictions' and 'opinions about MTS'. This coding was then inductively differentiated and iteratively reviewed to explore nurses' discretionary use of guidelines. Although the analysis proceeded without use of any established system for reliability checking, I sought to reduce researcher bias by sharing preliminary drafts with colleagues and informants, delivering oral presentations to members of the field and briefly re-entering the field at a later stage to test tentative conclusions. The results of this process are presented below.

\section{Analysis}

This section describes how triage nurses used discretion when assessing and prioritising patients. Following a review of MTS guidelines, I detail how nurses deviated from these when assessing the urgency of patients' complaints. Finally, I describe how nurses sought to 
override MTS when faced with discrepancies between their own assessment and guideline recommendations.

\section{Manchester Triage System}

In the participating EPCC, MTS was the official system for urgency assessments. This is a paper-based licensed triage system comprising 53 flow charts ordered after 'chief complaints' such as abdominal pain, allergy, ear problems and head injury. Each flow chart consists of 'discriminators' - clinical signs and symptoms related to the chief complaint. Within each chart, discriminators are ordered in a hierarchy of five colour-coded triage codes: red (most urgent), orange, yellow, green and blue (least urgent). MTS instructs nurses to start from the top of the chart and to rule out discriminators one by one until they find a positive match, which determines the patient's triage code. This system also instructs nurses to consider discriminators 'without making any assumptions about the [patient's] diagnosis' (Mackway-Jones et al. 2014: 11). The top three codes specify maximum waiting times; while red patients are to receive immediate medical attention, orange and yellow patients are to see a physician within ten and 60 minutes, respectively.

Nurses were eligible for triage after working for approximately one year in the EPCC. They would then have to read the MTS manual (Mackway-Jones et al. 2014), attend a full-day triage course and practise the system for three full shifts under the supervision of a triage instructor.

During the triage course, the instructors, who were themselves nurses, communicated MTS prescriptions somewhat ambiguously. On the one hand, they stressed the importance of adhering to the system; on the other, they encouraged participants to supplement MTS with their professional knowledge and skills. For instance, instructor Isabel made the following claim: 'Manchester triage is made to guide triage nurses. It's a tool we use to make the right decisions. We cannot turn off our brain and just fill out the form - we have to think like nurses, all the time'. These diverging messages illustrate a tension between managerial and professional ideology also reported in other studies (Flynn 2002, Russell 2012). ${ }^{4}$ The rest of this analysis shows how the triage nurses I observed - especially those who were more experienced - resolved this tension in favour of professionalism.

\section{Discretionary assessments}

Shadowing nurses in triage taught me that their assessments were not reducible to MTS prescriptions. Although there was some overlap, nurses commonly departed from the guidelines by collecting supplementary data, engaging in differential diagnostic and holistic reasoning, relying on emotion and intuition and allowing colleagues, patients or patients' relatives to influence them. Each of these elements is considered in turn below.

Supplementary data In assessing urgency, nurses typically engaged in data collection beyond that prescribed by MTS discriminators. This was especially the case when complaints could not be reduced unambiguously to MTS classifications. While some additions reflected weaknesses in MTS and institutional requirements for triage assessment, others were initiated by the nurses themselves. Examples of the latter include making broader assessment of a patient's medical history and medications and using one's 'clinical gaze' to identify cues that escape the MTS system.

This supplementary work was facilitated in part by SBAR, another standard specifying what nurses should document in triage. SBAR stands for 'situation' (a paragraph about the patient's complaint); 'background' (relevant medical history and medications); 'assessment' (vital parameters and test scores) and 'recommendation' (listing of one's chosen flow chart and discriminator). Managers expected thorough documentation according to SBAR to enable nurse 
coordinators to sort patients within each triage code, which was crucial when patient volume was high. Thus, some deviations from MTS can be understood in light of this partially competing standard.

Differential diagnostics In addition to SBAR, nurses' supplementary data collection was facilitated by their own diagnostic knowledge. In one interview, Nurse Alice explained nurses' diagnostic approach as follows.

We're not allowed to diagnose patients; doctors do that. But of course, we know about diagnoses; we know what their symptoms are. It's not like this is unknown to us. So, we're thinking along the lines of 'Could this patient have had a transient ischemic attack, TIA?' things like that. 'Could he have had neurological manifestations?' With issues like fainting, syncope as we call it, we always ask 'Do you remember what happened before you fainted?' And then you have those patients who don't remember anything happening. That's not reflected in the flow chart; the only thing included there is whether you've been unconscious. And that gives you a yellow priority. But not remembering anything from before the incident [...] I would make it an orange priority because you haven't had any pre-warning, which makes one suspect that it could be cardiac-related.

Alice's account suggests that nurses know about correlations between symptoms, signs and diagnoses, and that they use this knowledge to collect additional data of relevance. Her comments were echoed by other nurses in the EPCC, who claimed to regularly use diagnoses as heuristics for assessing symptoms and signs beyond those suggested in MTS. In other words, nurses engaged in differential diagnostic reasoning - hypothesising and seeking to rule out or confirm possible diagnoses of the patient's complaint. By suggesting prognoses, diagnoses enable nurses to anticipate the potential development of the patient's condition and so judge how long they can wait before receiving medical attention.

Nurses typically limited their diagnostic hypotheses to acute, severe and treatable conditions, as these, in line with the EPCC's mandate, indicate a need for swift medical intervention. Their diagnostic hypotheses were low in specificity, usually entailing broad disease categories such as myocardial infarction or sepsis, as is common in frontline institutions (Armstrong 2011). For that reason, nurses' prognoses were more impressions than clear-cut predictions, with suspected rather than expected or certain trajectories. Nonetheless, as these suspicions were often considered more accurate than MTS recommendations, they could be significant for priority setting, as illustrated in Nurse Alice's claim about upgrading a patient's priority.

Nurses' differential diagnostic reasoning is clearly at odds with the MTS's prescription to consider only symptoms and signs, not diagnoses. However, triage nurses argued that diagnostic reasoning is a necessary and potentially life-saving supplement because the MTS system is inadequate for certain acute severe conditions. In the words of nurse Lindsay, 'If you don't know anything and just follow the manual, things might quickly go wrong'.

Holistic reasoning Nurses also deviated from MTS prescriptions by considering symptoms, signs and risk factors as a whole. Consider Nurse Judith's reasoning after she assessed a patient who feared she had meningitis. After the patient left triage, Judith explained:

I understand her worry about [previously having] fever, headache and neck pain, but at the same time, there was a lot that didn't fit the overall picture. That she had pains in her arms and legs, chest pain, and so on, and that she's better today - that definitely goes against 
meningitis and indicates the flu or similar. And her general wellbeing, that's a good sign having meningitis often makes you really tired. Even more, she didn't have any fever.

It is clear here that Judith weighed symptoms and signs against each other to determine the likelihood of meningitis, and this was a common practice among the nurses I observed. This holistic weighing of information was in marked contrast to the prescribed atomism of MTS, namely, considering discriminators one by one. When nurses nonetheless engaged in holistic reasoning, it was because they believed that this would enable more precise priority setting than the individual consideration of symptoms suggested by MTS.

It is worth noting that extra-clinical information often informed nurses' holistic reasoning, as when inferences about patient types intersected with their clinical reasoning. An example of this was Nurse Judith's remark that an elderly male patient's age was a medical risk factor, as well as indicating that his complaint should be trusted because 'He's from a generation where people don't complain'. Her words illustrate how social typifications constituted a form of metadata in judging the credibility of patients' signs and symptoms. Nurses also drew on typifications of this kind to make broader assessments about how patients would cope while waiting to see a physician. For instance, because children, older patients and those considered mentally unstable were believed to be less able to cope with long waiting times, nurses ensured that these patients were taken care of during their wait, occasionally even upgrading their triage code. In drawing on such extra-clinical information, nurses took account of a broader set of patient-related information than suggested by the MTS. This illustrates how clinical reasoning - even when reductively oriented to threats to a patient's body or mind depends on 'cognitive resources made available by membership of a wider cultural formation' (Hughes 1977: 139).

Emotion and intuition Complementing the more explicable sides of nurses' clinical reasoning, the influence of intuition and emotion represented a third deviation from MTS prescriptions. This was most in evidence when nurses sensed that a patient's condition was urgent, even though they were unable to articulate any explicit evidence of that urgency. They referred to this as 'a bad gut feeling' and claimed that this emotional evidence could influence their estimation of a patient's wait time. For instance, Nurse Andre said 'We often make assessments based on our gut feeling. There's a lot of people you feel can't wait for five hours'. His assertion reveals an impressionistic aspect of nurses' prognostication, which goes beyond the affect-neutral image of triage in MTS.

Nurses and managers were somewhat ambivalent about this reliance on emotion and intuition; many believed it could result in arbitrary or biased priority setting, especially amongst neophyte nurses. However, they also claimed that the gut feelings of more experienced nurses were crucial in identifying patients who might otherwise be at risk of falling between the cracks of MTS. On that basis, a 'bad gut feeling' was to some extent an institutionally recognised basis for setting priorities, especially in the case of a more experienced nurse. These views are congruent with other research findings that show intuition to be an essential (if poorly regarded) aspect of expert practice (Benner and Tanner 1987, Gobet and Chassy 2008, King and Appleton 1997).

In summary, triage nurses often relied on their emotions and intuition when setting priorities, and this was seen as a necessary (though not unproblematic) addition to the affect-neutral logic of MTS.

Interaction A final point of interest about triage nurses' assessments is that they were interactively constructed. For instance, nurses interacted with patients and patients' relatives, who 
could significantly influence nurses' assessments by emphasising some issues at the expense of others. Occasionally, those presenting in triage also made explicit attempts to negotiate their triage code. Although these attempts rarely succeeded, they demonstrated that patients and their relatives were far from the passive purveyors of information implied in the MTS manual (see Edwards and Sines 2008 for a similar argument).

Nurses' interactions with colleagues also influenced their assessments. In general, they would confer with colleagues - typically their 'neighbour' in triage or the nurse coordinator when seeking a second opinion. Colleague interaction was often deliberative, making it difficult to discern a definitive 'source' for the decision and illustrating how triage decision making was often 'distributed' (Goodwin 2014, Rapley 2008). None of this is reflected in the MTS manual, which assumes that a single decision-maker is responsible for priority setting.

It is also important to acknowledge that assessments were influenced by interaction with non-human artefacts (Nicolini 2012), such as diagnostic technology, frameworks of knowledge, and, most importantly here, the MTS. Despite the deviations described above, it would be an exaggeration to claim that nurses assessed patients wholly independently of guidelines. MTS did in fact regulate nurses' practice by serving as a 'bare minimum' of information to be considered and documented, to which nurses were held accountable by colleagues and superiors. Accordingly, nurses' discretionary assessments were often pigeonholed into the official categories of MTS. Moreover, although nurses rarely, if ever, had the manual in front of them during the triage encounter, they often consulted MTS towards the end of the assessment in case they had forgotten to check for relevant symptoms and signs. Nurses also relied on MTS in situations where they were unsure how to assess patients. Therefore, despite underdetermining and often misrepresenting triage nursing practice, the MTS guidelines clearly influenced nurses' urgency assessments in a sociologically noteworthy sense.

\section{Triage code adjustments}

In this subsection, I will delve deeper into when, how and why nurses' privileged their own assessments over MTS recommendations. To understand when, it is necessary to revisit the association of MTS triage codes with target waiting times. When assigning patients to a triage code, triage nurses must ask themselves two questions: is the recommended waiting time (1) reasonable and (2) realistic for this particular patient? The first question concerns whether the MTS waiting time accords with the nurse's own assessment; the second concerns whether this waiting time is attainable given the ratio of patients to physicians at the moment of assessment. When nurses believed the MTS-suggested waiting time to be unreasonable and/or unrealistic, their choice of triage code often deviated from MTS recommendations.

To understand how nurses navigated MTS, it is important to consider the organisation's rules for priority setting. While EPCC management allowed nurses to upgrade patients' triage code if they provided a reason in the triage note, downgrading was strictly prohibited. To downgrade patients (or keep their upgrades 'off radar'), nurses had to employ more covert methods, of which I observed three main types. Note, however, that not every nurse was found to engage in covert practice, perhaps because of individual differences among nurses and/or differences in the cases I observed. Nonetheless, it is fair to assume that the prevalence of covert practices was greater than what I, a sociologist 'outsider', was allowed to observe.

Qualifying discriminators One covert practice involved qualifying discriminators. As mentioned, this was characterised as 'strictly prohibited' by a triage course instructor, but some nurses were observed to do so nonetheless. For instance, when assessing a three-year-old boy, 
Nurse Alyssa qualified the discriminator 'new abnormal pulse'. The boy's pulse was first measured as 150 and then 100, before stabilising at 118; this was eight points above the discriminator limit for his age group and should have resulted in an orange triage code. However, Alyssa reasoned that the fluctuation, in combination with the boy's dry, warm skin, normal skin colour and otherwise good general condition were strong enough reasons to disregard his slightly increased pulse. On that basis, she gave him a yellow triage code, later explaining that she preferred to consider him 'as a whole' rather than prioritising on the basis of single symptoms, which illustrates the importance of nurses' holistic reasoning. She also added that this was a breach of EPCC policy: 'If it [the pulse] is abnormal, then I'm really not allowed to skip past it'.

This example raises the question of why Alyssa overrode the system. Part of the answer is that triage codes are a scarce commodity that must be rationed; if everyone receives high priority then no one receives high priority. Many nurses referred to MTS as an 'overtriage tool', in that it assigns too high a priority to certain complaints. For that reason, they felt the need to 'correct' MTS, especially in (the relatively frequent) situations of overcrowding, in which waiting times increased and more refined queue ordering was required. It is also worth noting that certain nurse managers expressed some understanding of deviations like Alyssa's. When asked if qualifying discriminators was acceptable in certain cases, Nurse Cindy, who taught triage courses and occasionally performed triage herself, answered as follows: 'I believe it's okay if you have some experience, but it's ... It's not what we teach them'. This implies that deviations like Alyssa's might go unsanctioned even when detected. Cindy's answer also highlights the salience of nurses' experience in downgrading patients. Downgrading was considered more legitimate - and was therefore more typical - among more experienced nurses like Alyssa, who had worked in the EPCC for several years.

Strategically choosing flow charts Another covert method for acting on one's own assessment was strategically choosing flow charts. For instance, Nurse Anne spent 6.5 minutes assessing a patient with a swollen forehead and concluded that the patient should receive a green triage code. Awarding this code required some reflexivity on Anne's behalf; after the patient had left triage, we discussed this.

Anne: $\quad$ Sometimes you have to manipulate the system a bit because, according to the manual, she would have been orange.

Researcher: What [discriminator] would she have got?

Anne: If I'd believed this was an allergic reaction, I could have used [the flowchart] Allergy, and then she'd get [the discriminator] 'Facial oedema'.

Researcher: So you have to reflect on which flowchart you choose?

Anne: Ideally, one is supposed to get the same priority regardless of the flowchart we use. But it's completely ridiculous for her to see a doctor within ten minutes; that's why I chose the chart facial problems instead.

In the facial problems chart, the patient would be positive for 'facial swelling', a green discriminator; in the Allergy chart, the patient's problem would constitute 'facial oedema', an orange discriminator. Anne's differential diagnosis excluded an allergic reaction, prompting her to estimate the patient's 'waitability' as significantly longer than the ten minutes suggested by the allergy chart. She therefore chose 'facial swelling' to ensure a triage code that better aligned with her own assessment. Similar practices allowed nurses to upgrade patients as well. Thus, nurses' knowledge about flowchart discrepancies allowed them to prioritise on the basis of their own discretion. 
Oral adjustments In some instances, nurses were unable or unwilling to engage in workarounds to adjust a patient's formal triage code. This most often related to certain orange discriminators; there were numerous examples of nurses giving orange triage codes despite their conviction that there was nothing seriously wrong with the patient. One telling example was Nurse Helen's comment after she had assigned two orange codes in a row:

Both were orange according to the chart, but none were orange in a clinical sense. $\mathrm{He}$ checked out on a discriminator used when one suspects stroke, but he had no other symptoms. He was a young man born in ' 84 , but he got orange nonetheless. The girl was orange just because she had a high pulse, but I believe that's due to her being anxious. Besides that, she was clinically fine, with perfectly fine parameters.

Although Nurse Helen's assessments conflicted with MTS, she adhered to the system's recommendations. This caution was informed by both patient safety and judicial reasons, clearly illustrating how MTS discriminators could limit nurses' discretionary space. However, Helen had another means of modifying patient priority. After these assessments, she left the booth for a few minutes; on her return, she explained:

I visited logistics and explained that I registered them as orange, but that they weren't clinically orange - I believe they can wait more than ten minutes. We're supposed to use our head too, in addition to the discriminators. I feel they could have been yellow, but you shouldn't skip those discriminators.

This example shows that while Nurse Helen was unwilling to perform an inter-code adjustment - that is, downgrading a patient's triage code - she was comfortable with making an intra-code adjustment - assigning the patient a lower priority within their triage code. This was done by communicating the discretionary assessment to the clinic's nurse coordinator, so influencing their internal queue, ${ }^{5}$ namely, their mental representation of patients' relative priority. This queue was more refined than the electronically recorded external queue, which ordered patients first by triage code and then by time of arrival. Because the coordinator often told those working 'inside' who should be prioritised, these informal messages could strongly influence patients' wait time before receiving medical attention. A similar practice served to move patients forward in line as well. Thus, such informal interactions allowed nurses to act on their discretionary assessments without appearing to violate guideline prescriptions.

\section{Discussion and concluding remarks}

The analysis has shown that nurses take an active approach (Russell 2012) to face-to-face triage, which is congruent with earlier findings on telephone triage. The analysis has also detailed the relationship between guideline deviations and nurses' clinical reasoning, which has been under-analysed in previous research. Nurses assessed patients at odds with MTS guidelines by collecting supplementary data, engaging in differential diagnostic and holistic reasoning, relying on emotion and intuition and allowing colleagues, patients or patients' relatives to influence their reasoning. Moreover, where nurses' discretionary assessment suggested that the system-prescribed wait time was either unreasonable or unrealistic, nurses sought to override the system by qualifying discriminators, strategically choosing flowcharts or orally adjusting urgency levels. Although the observed characteristics are unlikely to be exhaustive of triage nurses' discretionary practices, the findings show how managerial tools may be significantly at 
odds with the professional reasoning they seek to regulate. These findings are particularly interesting because most nurses in this EPCC, including those I shadowed, had no experience with triage before being introduced to MTS. Despite their co-occurring socialisation into triage nursing and MTS, they nevertheless employed significant discretion when assessing patients.

However, triage nurses did not operate completely independently of the guidelines. MTS served as a support system and checklist, holding nurses accountable to a minimum of symptoms and signs to be considered in their assessments and documentation. Nurses' assessments therefore synthesised their own professional judgment with system-prescribed considerations; rather than simply disregarding guidelines, they used them reflexively by drawing on some parts rather than others, supplementing or circumventing them when it was considered necessary to ensure fair and correct priority setting. In short, nurses assessed patients' urgency in negotiation (Strauss et al. 1963) with MTS.

The present findings are difficult to subsume under the existing conceptualisations of triage nurses' use of guidelines. In acknowledging the joint influence of nurse and guideline in triage assessments, the notion of 'dual triage' (O'Cathain et al. 2004b) mentioned above might appear promising. However, this idea does not reflect the full extent of how triage nurses supplemented, translated and contravened guidelines. Additionally, the term 'dual' does not do justice to the complexity of these assessments; influences on triage assessments are not just dual, they are multiple.

The findings here are better aligned with the concept of 'mindlines', referring to collectively reinforced, internalised, tacit guidelines (Gabbay and le May 2004, 2011). While Gabbay and le May's (2011: 12) concept was based primarily on observations of doctors, they argued for its application to other professionals as well. On that basis, I propose the term 'triage mindlines' to conceptualise how nurses assess patients using internalised guiding principles derived from professional socialisation and personal experience, as well as interaction with colleagues, triage instructors, management, MTS and other sources. These guiding principles can be articulated to some degree, but they also encompass tacit knowledge (Polanyi 1967), such as a nurse's ability to judge a patient's general condition, which is crucially important for identifying those most at risk. ${ }^{6}$ Because they encompass a broader range of knowledge than MTS, triage mindlines structure the triage encounter in terms of a more situated, individualised logic than the abstract, procedural prescriptions of MTS.

One likely reason for nurses' greater reliance on triage mindlines than on MTS guidelines is the dual reductionism of rule-based systems. As argued in previous research, such systems exclude nurses' situated, tacit knowledge, and the limited set of information these systems provide cannot account for all the contingencies of everyday work practice (cf. Berg 1997, Dew et al. 2010, Greatbatch et al. 2005, Heath and Luff 2000, Suchman 1987, Tjora 2000). A second and related reason is that the MTS prescription of atomistic and non-diagnostic reasoning imposes too strict a boundary between nursing and medicine. Nurses' knowledge makes such a boundary difficult to maintain in practice, as evidenced here and in other studies (e.g. Allen 1997, Butler et al. 2009, Hughes 1988, Tjora 2000). A third reason for nurses' reliance on triage mindlines is that they must consider several standards (e.g. MTS and SBAR) when making triage assessments. As previous research has focused almost exclusively at one standard at a time, this discretionary balancing of several competing standards warrants further research. A fourth reason - differentiating this EPCC from many other EMS organisations (cf. Ruston 2006, Tjora 2000) - is that neither management nor the system's design demanded absolute adherence to the guidelines. Instead, management expected triage nurses to supplement MTS with their professional knowledge and experience, and the paper-based MTS guidelines allowed for significantly more discretion than computer-based triage guidelines typically do (cf. Bjørn and Balka 2007). Moreover, even if management had required nurses to adhere completely to the system, the light monitoring regime for face-to-face triage - as opposed to 
telephone triage, where nurses often practice in front of superiors and conversations are typically recorded - allowed nurses more freedom to exercise their own discretion. A fifth and final reason relates to nurses' pragmatism. As Timmermans and Berg (2003: 70) argued, healthcare professionals regard guidelines as means rather than ends, adhering to them only if they are considered useful for the task at hand. This was not always the case in the participating EPCC; indeed, in line with findings from other studies (Dowding et al. 2009, Ruston 2006), nurses believed that strict adherence to the MTS could pose a risk for certain patients. Their discretionary practice was therefore motivated, at least partially, by a pragmatic focus on helping patients by overcoming the limitations of the system.

That said, the present findings do not imply that the EPCC would be better off without the MTS, or that procedural standards in general are detrimental to patients or healthcare workers. Both managers and nurses were largely satisfied with the system while acknowledging that it had limitations, and that some of these were quite severe. While an assessment of the success of the MTS would require a different research design, the present findings reveal a problematic tension between nurses' reasoning and MTS assumptions about this reasoning. Guideline developers could reduce these tensions by paying closer attention to how professionals reach decisions for instance, by taking account of nurses' tendency to reason in a differential diagnostic and holistic manner (cf. Edwards 1994). The findings also illustrate some limitations in the regulatory force of procedural standards. As no rule can exhaustively prescribe every aspect of a practice, those developing and enforcing guidelines might usefully adopt Timmermans and Epstein's (2010: 81) view that 'The trick in standardization appears to be to find a balance between flexibility and rigidity and to trust users with the right amount of agency to keep a standard sufficiently uniform for the task at hand'. More grandiose ambitions, such as demanding absolute adherence to guideline prescriptions or arguing that, 'There is a need for a uniform triage scale that is suitable for all services' (Azeredo et al. 2015: 47), are likely to prove dead ends.

Although confinement to a single research site precludes statistical inference, the present analysis provides an in-depth understanding of guideline application within this particular institutional setting. It seems likely that the findings will prove relevant in understanding the use of procedural guidelines in other settings, especially where relatively experienced professionals work to assess complex (medical) problems under high workloads and less than total monitoring. More generally, the findings here illustrate the difficulties of imposing a managerial logic on professional labour (Flynn 2002, Lam 2000, Townley 2002) and the crucial role of additional skills and knowledge in making guidelines work (Ruston 2006; Timmermans and Berg 2003). These considerations should be kept in mind when designing and implementing guidelines in professional organisations.

Address for correspondence: Lars E.F. Johannessen, Oslo and Akershus University College of Applied Sciences - Centre for the Study of Professions, PB 4 St. Olavs plass, Oslo 0130, Norway.E-mail: lars.johannessen@hioa.no

\section{Acknowledgements}

I would like to thank Dag Album, Erik B. Rasmussen, colleagues in my research group at the Centre for the Study of Professions and my anonymous reviewers for their comments and suggestions.

\section{Notes}

1 In Norwegian, EPCCs translates as legevakt. 
2 Exceptions pertaining to face-to-face triage include Dowding et al. (2009) and the studies reviewed by Johannessen (2016). The former includes face-to-face triage as only one of four case studies; the latter reviews descriptive studies that focus more on decision-making in general than on nurses' use of guidelines. Neither provides firm grounds for any conclusions about guideline application in faceto-face triage.

3 Relevant questions include: 'What are your thoughts on having to use MTS in your assessments?'; 'Beyond MTS, what influences your allocation of triage codes?' and 'What is the most challenging aspect of performing triage?'

4 A similar ambiguity characterises the MTS manual, but the MTS system itself is unequivocally built on an algorithmic and managerial logic.

5 I learned about this 'internal' queue by shadowing nurse coordinators and probing them about their queue management.

6 The relevance of nurses' tacit knowledge became apparent whenever I tried to use the MTS manual myself. As a sociologist and non-nurse, my underdeveloped 'clinical gaze' meant that I could not arrive at the same conclusions as the nurses I shadowed.

\section{References}

Allen, D. (1997) The nursing-medical boundary: a negotiated order?, Sociology of Health \& Illness, 19, 4, 498-520.

Armstrong, D. (2011) Diagnosis and nosology in primary care, Social Science \& Medicine, 73, 6, $801-7$.

Azeredo, T.R.M., Guedes, H.M., Rebelo de Almeida, R.A., Chianca, T.C.M., et al. (2015) Efficacy of the Manchester Triage System: a systematic review, International Emergency Nursing, 23, 2, 47-52.

Bazeley, P. (2007) Qualitative data analysis with NVivo. Los Angeles: Sage.

Benner, P. and Tanner, C. (1987) Clinical judgment: how expert nurses use intuition, The American Journal of Nursing, 87, 1, 23-31.

Berg, M. (1997) Problems and promises of the protocol, Social Science \& Medicine, 44, 8, 1081-8.

Berg, M., Horstman, K., Plass, S. and Van Heusden, M. (2000) Guidelines, professionals and the production of objectivity: standardisation and the professionalism of insurance medicine, Sociology of Health \& Illness, 22, 6, 765-91.

Bjørn, P. and Balka, E. (2007) Health care categories have politics too: Unpacking the managerial agendas of electronic triage systems. In Bannon, L.J., Wagner, I., Gutwin, C., Harper, R.H.R., et al. (eds) ECSCW 2007. London: Springer.

Butler, C.W., Danby, S., Emmison, M. and Thorpe, K. (2009) Managing medical advice seeking in calls to Child Health Line, Sociology of Health \& Illness, 31, 6, 817-34.

Dew, K., Stubbe, M., Macdonald, L., Dowell, A., et al. (2010) The (non) use of prioritisation protocols by surgeons, Sociology of Health \& Illness, 32, 4, 545-62.

Dowding, D., Mitchell, N., Randell, R., Foster, R., et al. (2009) Nurses' use of computerised clinical decision support systems: a case site analysis, Journal of Clinical Nursing, 18, 8, 1159-67.

Edwards, B. (1994) Telephone triage - how experienced nurses reach decisions, Journal of Advanced Nursing, 19, 4, 717-24.

Edwards, B. and Sines, D. (2008) Passing the audition - the appraisal of client credibility and assessment by nurses at triage, Journal of Clinical Nursing, 17, 18, 2444-51.

FitzGerald, G., Jelinek, G.A., Scott, D. and Gerdtz, M.F. (2010) Emergency department triage revisited, Emergency Medicine Journal, 27, 2, 86-92.

Flynn, R. (2002) Clinical governance and governmentality, Health, Risk \& Society, 4, 2, 155-73.

Gabbay, J. and le May, A. (2004) Evidence based guidelines or collectively constructed 'mindlines?' Ethnographic study of knowledge management in primary care, BMJ, 329, 1013.

Gabbay, J. and le May, A. (2011) Practice-based evidence for healthcare: clinical mindlines. London: Routledge. 
Germov, J. (2005) Managerialism in the Australian public health sector: towards the hyper-rationalisation of professional bureaucracies, Sociology of Health \& Illness, 27, 6, 738-58.

Gobet, F. and Chassy, P. (2008) Towards an alternative to Benner's theory of expert intuition in nursing: A discussion paper, International Journal of Nursing Studies, 45, 1, 129-39.

Goodwin, D. (2014) Decision-making and accountability: differences of distribution, Sociology of Health \& Illness, 36, 1, 44-59.

Greatbatch, D., Hanlon, G., Goode, J., O'Cathain, A., et al. (2005) Telephone triage, expert systems and clinical expertise, Sociology of Health \& Illness, 27, 6, 802-30.

Halvorsen, K.S., Nilsen, J.E. and Olsen, J.A. (2014) Triage $i$ den akuttmedisinske kjeden [Triage in the emergency medical services] (NAKOS report 2/2014). Oslo: Helsedirektoratet.

Hanlon, G., Strangleman, T., Goode, J., Luff, D., et al. (2005) Knowledge, technology and nursing: The case of NHS Direct, Human Relations, 58, 2, 147-71.

Heath, C. and Luff, P. (2000) Technology in action. Cambridge: Cambridge University Press.

Heritage, J. (1984) Garfinkel and ethnomethodology. Cambridge: Polity Press.

Hughes, D. (1977) Everyday and medical knowledge in categorizing patients. In Dingwall, R., Heath, C., Reid, M. and Stacey, M. (eds) Health care and health knowledge. London: Croom Helm.

Hughes, D. (1988) When nurse knows best: some aspects of nurse/doctor interaction in a casualty department, Sociology of Health \& Illness, 10, 1, 1-22.

Johannessen, L.E.F. (2016) How triage nurses use discretion: A literature review, Professions and Professionalism, doi: http://dx.doi.org/10.7577/pp.1446.

King, L. and Appleton, J.V. (1997) Intuition: a critical review of the research and rhetoric, Journal of Advanced Nursing, 26, 1, 194-202.

Kirkpatrick, I., Jespersen, P.K., Dent, M. and Neogy, I. (2009) Medicine and management in a comparative perspective: the case of Denmark and England, Sociology of Health \& Illness, 31, 5, 642-58.

Lam, A. (2000) Tacit knowledge, organizational learning and societal institutions: An integrated framework, Organization Studies, 21, 3, 487-513.

Lampland, M. and Star, S.L. (2009) Standards and their stories: how quantifying, classifying, and formalizing practices shape everyday life. New York: Cornell University Press.

Light, D. and Levine, S. (1988) The changing character of the medical profession: a theoretical overview, The Milbank Quarterly, 66, Suppl 2, S10-32.

Mackway-Jones, K., Marsden, J., Windle, J. and Manchester Triage Group (2014) Emergency triage. 3rd edn. Chichester: Wiley.

Mintzberg, H. (1979) The structuring of organizations: a synthesis of the research. Englewood Cliffs, NJ: Prentice-Hall.

Murdoch, J., Barnes, R., Pooler, J., Lattimer, V., et al. (2015) The impact of using computer decisionsupport software in primary care nurse-led telephone triage: interactional dilemmas and conversational consequences, Social Science \& Medicine, 126, 36-47.

Nicolini, D. (2012) Practice theory, work, and organization: an introduction. Oxford: Oxford University Press.

Norwegian Board of Health Supervision (2008) 'Mens vi venter..'-forsvarlig pasientbehandling $i$ akuttmottakene? ['While we are waiting..'-do patients receive adequate treatment in accident and emergency units?]. Oslo: Statens helsetilsyn.

Numerato, D., Salvatore, D. and Fattore, G. (2012) The impact of management on medical professionalism: a review, Sociology of Health \& Illness, 34, 4, 626-44.

O'Cathain, A., Nicholl, J., Sampson, F., Walters, S., et al. (2004a) Do different types of nurses give different triage decisions in NHS Direct? A mixed methods study, Journal of Health Services Research \& Policy, 9, 4, 226-33.

O'Cathain, A., Sampson, F.C., Munro, J.F., Thomas, K.J., et al. (2004b) Nurses' views of using computerized decision support software in NHS Direct, Journal of Advanced Nursing, 45, 3, 280-6.

Polanyi, M. (1967) The tacit dimension. Garden City: Doubleday.

Randell, R., Mitchell, N., Thompson, C., McCaughan, D., et al. (2009) Supporting nurse decision making in primary care: exploring use of and attitude to decision tools, Health Informatics Journal, 15, 1, 516. 
Rapley, T. (2008) Distributed decision making: the anatomy of decisions-in-action, Sociology of Health \& Illness, 30, 3, 429-44.

Russell, B. (2012) Professional call centres, professional workers and the paradox of the algorithm: the case of telenursing, Work, Employment \& Society, 26, 2, 195-210.

Ruston, A. (2006) Interpreting and managing risk in a machine bureaucracy: professional decision-making in NHS Direct, Health, Risk \& Society, 8, 3, 257-71.

Sheaff, R., Rogers, A., Pickard, S., Marshall, M., et al. (2003) A subtle governance: 'soft' medical leadership in English primary care, Sociology of Health \& Illness, 25, 5, 408-28.

Strauss, A., Schatzman, L., Ehrlich, D., Bucher, R., et al. (1963) The hospital and it's negotiated order. In Freidson, E. (ed) The hospital in modern society. New York: Free Press.

Suchman, L.A. (1987) Plans and situated actions: the problem of human-machine communication. Cambridge: Cambridge University Press.

Timmermans, S. and Berg, M. (1997) Standardization in action: achieving local universality through medical protocols, Social Studies of Science, 27, 2, 273-305.

Timmermans, S. and Berg, M. (2003) The gold standard: the challenge of evidence-based medicine and standardization in health care. Philadelphia: Temple University Press.

Timmermans, S. and Epstein, S. (2010) A world of standards but not a standard world: Toward a sociology of standards and standardization, Annual Review of Sociology., 36, 1, 69-89.

Tjora, A. (2000) The technological mediation of the nursing-medical boundary, Sociology of Health \& Illness, 22, 6, 721-41.

Tolich, M. (2004) Internal confidentiality: when confidentiality assurances fail relational informants, Qualitative Sociology, 27, 1, 101-6.

Townley, B. (2002) Managing with modernity, Organization, 9, 4, 549-73. 



\section{Article 2}

Johannessen, L.E.F. (2018). Workplace assimilation and professional jurisdiction: How nurses learn to blur the nursing-medical boundary. Social Science \& Medicine 201: 51-58. 



\title{
Workplace assimilation and professional jurisdiction: How nurses learn to blur the nursing-medical boundary
}

\author{
Lars E.F. Johannessen \\ Centre for the Study of Professions, OsloMet - Oslo Metropolitan University, Pb. 4, St. Olavs plass, 0130 Oslo, Norway
}

\section{A R T I C L E I N F O}

\section{Keywords:}

Norway

Boundaries

Discretion

Guidelines

Jurisdiction

Knowledge

Learning

Workplace assimilation

\begin{abstract}
A B S T R A C T
In theorising 'the system of professions', Andrew Abbott emphasised how jurisdictional boundaries in the workplace are far fuzzier than those specified in law. A key reason for this fuzziness is the process he characterised as 'workplace assimilation', involving on the job learning of a craft version of another profession's knowledge system. However, despite its centrality, workplace assimilation remains poorly elaborated in the scholarly literature. To address this shortcoming, this study explores the workplace assimilation of nurses in a Norwegian emergency primary care clinic. Using an ethnographic approach, the study shows how nurses learned to blur the nursing-medical boundary by (1) doing physician-like work; (2) interacting with their colleagues; (3) comparing their own clinical assessments to those of physicians (as codified in the patient record) and (4) using medical reference works to guide their clinical decision making. In detailing these aspects of workplace assimilation, the study illuminates how and why workers come to blur jurisdictional boundaries in the workplace.
\end{abstract}

\section{Introduction}

In his seminal work The System of Professions, Andrew Abbott (1988) theorised how professions compete for jurisdiction-that is, for control over particular tasks. This form of competition occurs mainly in the judicial system, the public sphere and the workplace; however, as Abbott noted, "There is a profound contradiction between the two somewhat formal arenas of jurisdictional claims, legal and public, and the informal arena, the workplace" (Abbott, 1988, p. 66). While the formal arenas specify clear jurisdictional boundaries between professionals, the workplace is a site where "formal lines of demarcation frequently break down" (Allen, 2001, p. 79).

A key reason for this breakdown is the process that Abbott characterised as workplace assimilation, defined as a "form of knowledge transfer" in which "[s]ubordinate professionals, nonprofessionals, and members of related, equal professions learn on the job a craft version of given professions' knowledge systems" (Abbott, 1988, p. 65). Although not comparable to the training required for full membership in a profession, workplace assimilation nevertheless enables members of one profession to carry out at least some of the tasks of another (Abbott, 1988, pp. 65-6).

The latter point has been richly described in studies of professionals' 'boundary-blurring work' (Allen, 1997), i.e. work that obscures formal jurisdictional boundaries. Most such studies have centred on healthcare organisations, with particular emphasis on 'the nursing-medical boundary' (Allen, 1997; Annandale et al., 1999; Apesoa-Varano, 2013;
Butler et al., 2009; Carmel, 2006a; Hughes, 1988; Liberati, 2017; Porter, 1991; Prowse and Allen, 2002; Salhani and Coulter, 2009; Snelgrove and Hughes, 2000; Stein, 1967; Stein et al., 1990; Svensson, 1996; Tjora, 2000; Walby and Greenwell, 1994). For instance, Hughes (1988) did participant observation in a casualty clinic and discovered that nurses frequently found themselves "moving close to areas of judgment for which the doctor takes legal responsibility" (Hughes, 1988, p. 5). Similarly, in a hospital ethnography, Allen (1997) found that ward-based nurses often had difficulty in reaching physicians working across wards, leading them to violate organisational policy to address pressing medical concerns when physicians were unavailable.

There is also evidence that nurses become more likely to blur boundaries as they gain work experience (cf. Allen, 1997; Hughes, 1988; O'Cathain et al., 2004; Xyrichis et al., 2017); consistent with the predictions of workplace assimilation, this suggests that nurses somehow learn to blur boundaries in the workplace. However, nurses' workplace learning has not been granted particular analytical interest; existing studies have largely been confined to the content and rationale of nurses' boundary-blurring work, with little attention to how nurses learn to blur the nursing-medical boundary in the first place. Tjora's (2000) study of emergency medical communication centres is a partial exception, as he mentions "how new knowledge is socially developed" through nurses' "discussion and evaluation of [their] own and others' practice" (Tjora, 2000, p. 734). Beyond this, however, little has been written about how workplace assimilation enables nurses to blur professional boundaries.

E-mail address: lars.johannessen@hioa.no. 
This deficit reflects a more general neglect of workplace assimilation in the scholarly literature. Abbott himself provided only a brief theoretical description of the concept (spread across 1988, pp. 64-8), and subsequent studies have noted only that workplace assimilation occurs in their given field, without exploring the actual learning mechanisms involved (cf. Evans and Honold, 2007; Kirkpatrick, 1999; O'Connor, 2009). This is unfortunate; in treating it as a unified whole, we risk overlooking salient variations in how, why and to what extent workplace assimilation occurs. These are questions of great significance in judging the soundness of boundary-blurring work, and in understanding the 'fuzziness' of workplace jurisdiction more generally. A fuller understanding of professional boundaries in the workplace therefore demands further investigation of the processes of workplace assimilation.

To that end, this ethnographic study explores workplace assimilation among nurses and physicians at a Norwegian emergency primary care clinic (EPCC; 'legevakt' in Norwegian). As frontline institutions dealing with high volumes of undifferentiated patients, some of whom may be critically ill, large-scale EPCCs like the one under study resemble emergency departments in other countries (Vassy, 2014). Although clearly not representative of all healthcare organisations, the inter-professional composition of the EPCC workforce and the significant overlap in work tasks makes this an ideal setting for exploring workplace assimilation.

The present article focuses in particular on how nurses learn to blur boundaries in the frontline role of face-to-face triage, where they assess the urgency of patients' complaints. While triage was demarcated by guidelines that distinguished clearly between nurses' assessments and physicians' consultations, nurses were found to routinely blur this boundary by performing triage assessments in ways that approximated the discretionary diagnostic and prescriptive work of physicians. The central research question, then, is how nurses learned to blur boundaries in this way. By delving deeply into this case of triage nursing, the aim is to extend our understanding of workplace assimilation, thus improving our knowledge of how and why formal divisions of professional labour become blurred in the workplace.

I continue by describing the study's theoretical perspective and its data and methods. In the subsequent findings section, I briefly describe the jurisdictional boundary separating triage nurses from physicians, and how nurses blurred this boundary when assessing patients. This is followed by a detailed analysis of the learning mechanisms underpinning nurses' boundary-blurring work, before I discuss the broader implications of the study's findings.

\subsection{Theoretical approach}

Before exploring nurses' workplace assimilation, it is important to clarify some key concepts. As mentioned, Abbott (1988, p. 65) viewed workplace assimilation as a form of "knowledge transfer", enabling members of one profession or occupational group to perform certain tasks that belong formally to another. In this, Abbott seems to understand knowledge in pragmatic terms as involving "a form of mastery that is expressed in the capacity to carry out a social and material activity" (Nicolini, 2012, p. 5). For present purposes, the knowledge of interest is commonly referred to as medical or clinical, relating to the practical tasks of identifying and treating medical conditions. This includes both the tacit skills underpinning clinical interpretation and reasoning, and more abstract explicit knowledge of medical topics (Polanyi, 1967). The question addressed here is how nurses develop sufficient clinical knowledge to blur the nursing-medical boundary. As suggested above, the bulk of this 'blur-enabling' knowledge is likely to be developed in the workplace.

Following Tÿnjälä (2008, p. 140), we can distinguish three basic modes of workplace learning: (1) incidental and informal learning that occurs as a 'side effect' of work, (2) intentional, non-formal learning related to work, such as the intentional practising of certain skills or tools; and (3) formal, on- and off-the-job training. This study focuses predominantly on the first type-informal workplace learning-which is most relevant for understanding the largely informal process of workplace assimilation. Following Eraut (2004), the distinction between informal and formal learning can be seen as a continuum, in which the informal end is characterised by unstructured learning in the absence of an official teacher. Such learning "may occur without the awareness or intention to learn (implicit learning), or it may involve a more or less deliberate effort to learn" (Ellström, 2011, p. 106).

The present analysis places particular emphasis on the situated nature of nurses' workplace learning-in other words, on "the relationship between learning and the social situation in which it occurs" (Lave and Wenger, 1991, p. 14). As such, learning is approached as "an external interaction process between the learner and his or her social, cultural and material environment" (Illeris, 2011, p. 35). Accordingly, the object of analysis here is nurses' learning environment and their interactions within it. On this view, learning is intimately connected with practice (i.e. the performance of work activities), both because practice itself involves learning and because it raises practical problems that nurses must solve (Ellström, 2011, pp. 105-6). Finally, the study also analyses learning through an ethnographic lens, which will be described in the following section.

\section{Data and methods}

Ethnography- "the study of groups and people as they go about their everyday lives" (Emerson et al., 2011, p. 1, p. 1)—offers an appropriate means of analysing the situated and interactive aspects of nurses' workplace assimilation, as it allows the researcher to study learning in situ, including those practices that informants might not necessarily identify as involving learning (Eraut, 2004). The study setting was a publicly funded Norwegian EPCC; located in the city centre, it performed more than 50,000 consultations per year, employed more than 100 nurses and physicians and was open for $24 \mathrm{~h}$ on every day of the week. Like emergency departments in other countries (Vassy, 2014), it allowed patients to walk in at their own discretion. The clinic was intended to serve patients with medical rather than surgical complaints. Spatially, it was divided into a 'frontline' (comprising a reception area, waiting room and triage booths) and an 'inside' area (consisting of another waiting room, a work station shared by nurses and physicians and a series of examination rooms).

Between April and December 2015, 47 fieldwork sessions were conducted at this EPCC; the average duration of each session was approximately $6 \mathrm{~h}$. As discussed in more detail below, nurses in the EPCC rotated between several stratified roles, developing knowledge in all of them. All of these roles were covered in the 35 sessions in which I shadowed nurses throughout (most of) their working day. On average, the participants had worked in the EPCC for approximately three years, and all had a bachelor's degree in nursing (as is required for the protected title of 'nurse' in Norway). Of the other twelve sessions, three were spent observing courses related to triage nursing and other topics, and nine were dedicated to shadowing physicians. I also conducted semi-structured interviews with seven nurses, two physicians and two managers, who were questioned, among other things, about roles and boundaries in the EPCC. Overall, studying both professional groups and stratifying my observations according to EPCC roles proved useful for exploring variations in workplace learning.

The interviews were transcribed verbatim. During fieldwork, I scribbled keywords and near-verbatim quotes on a notepad or laptop for later reference when writing more elaborate, low-inference field notes. Totalling approximately 1270 single-spaced pages, all notes were written in Norwegian; in translating the extracts included in this article, I have made minor grammatical and aesthetic adjustments.

The study was approved by the Norwegian Social Scientific Data Services. Pseudonyms are used to secure informants' internal and external confidentiality (Tolich, 2004), and no other identifying 
information is disclosed. I signed a non-disclosure agreement with the participating EPCC. Workers were informed about the project both orally and in writing, and all informants gave their verbal consent to participation. When interacting with patients, each EPCC worker I shadowed would ask the patient whether it was acceptable that I witnessed their interaction.

From an early stage of this fieldwork, the collected data were sorted into emergent broad-brush codes, using QSR NVivo 10. Prior to commencing fieldwork, I was interested in what and how nurses learn in the EPCC; however, my interest in workplace assimilation was significantly heightened after leaving the field, when I engaged in an abductive process (Timmermans and Tavory, 2012) of alternate reading of field notes and the literature related to workplace jurisdiction. In pursuing this interest, I inductively differentiated and iteratively reviewed relevant broad-brush codes to explore how nurses develop blur-enabling knowledge. The results of this process are presented in the next section.

\section{Findings}

In the following, I briefly describe the jurisdictional boundary between triage nursing and medicine in the research setting, and how nurses blurred this boundary in their everyday assessments. This is followed by a detailed analysis of how nurses learned to engage in this boundary-blurring work.

\subsection{Boundaries}

As argued by Walby and Greenwell (1994, p. 86), triage challenges traditional boundaries between nursing and medicine by allowing nurses to engage in assessment work that resembles physicians' consultations. In this respect, triage reflects a broader trend within healthcare organisation, where an increasing number of tasks are being delegated from medicine to other professions (Nancarrow and Borthwick, 2005). However, as is typical for delegated work, the triage nurses I observed were restricted in ways that physicians were not. This was most clearly articulated in the main guideline governing triage assessments in this EPCC: the Manchester Triage System (MTS), which is the most widely used in Europe (Mackway-Jones et al., 2014).

Like most triage systems, the MTS is a procedural standard (Timmermans and Epstein, 2010), specifying how urgency assessments are to be performed. EPCC nurses were thoroughly socialised into this system; before being allowed to practice triage, they were required to read the MTS handbook, to attend a full-day triage course and to rehearse the system for three full shifts under the supervision of a triage instructor. The system itself is designed as a paper-based manual, consisting of 53 flow charts that are organised by categories of complaint such as abdominal pain, allergy, ear problems and head injury. Nurses are required to assess patients using one of the 53 charts, each specifying symptoms and signs that are of relevance for priority setting, ordered in a hierarchy of five colour-coded levels of urgency. The MTS instructs nurses to start from the top of the chart and to rule out symptoms and signs, one by one, until they find a positive match, which then determines the patient's triage code. The system also instructs nurses to assess patients "without making any assumptions about the [patient's] diagnosis" (Mackway-Jones et al., 2014, p. 11). In other words, the MTS specifies both what information nurses should collect about patients, how they should reason about this information, and what decisions should follow from these guideline-specified conclusions. In this way, the MTS imposes strict limitations on nurses' diagnostic and prescriptive decision-making.

It should be noted that the MTS handbook specifies that the system is meant to "inform" rather than fully determine the triage process (Mackway-Jones et al., 2014, p. xi). However, the handbook is less clear about the acceptable level of discretion. In the course that nurses were required to attend before practising triage, they were instructed to adhere closely to the system. Accordingly, nurses typically regarded the system as 'the norm' for patient assessment. As adopted in this clinic, then, the MTS articulated a clear formal boundary between triage nurses and physicians.

\subsection{Blurring}

As in previous triage studies (cf. Johannessen, 2016; PurcStephenson and Thrasher, 2010), the participating nurses were observed to deviate from the guidelines, and thus blur the MTS-articulated boundary in several ways. For instance, it was evident that nurses regularly considered diagnoses during their assessments. As discussed more extensively elsewhere (Johannessen, 2017), nurses were found to engage in differential diagnostic reasoning, hypothesising diagnoses of relevance to patients' presenting complaints. This often led nurses to adjust triage codes, thus overriding system recommendations. In some assessments, nurses were observed to approximate physicians' diagnosis and treatment to an even greater extent. Consider the following field note extract of how a patient was assessed and handled in triage:

Nurse Joachim receives an English-speaking mother and a child with spots on his face and body. He examines the child for a while before calling on the neighbouring triage nurse for a second opinion. She takes a close look before deciding, "It's chickenpox". Nurse Joachim replies "It is, isn't it?" The second nurse suggests that he should send the patient to the pharmacy to buy an ointment and some painkillers. "There's nothing we can do in any case", she concludes. Nurse Joachim conveys this information to the patient's mother, who replies that she thought they could get a vaccine. He assures her that it will all be over in a week and that there is nothing they can do about it. The mother asks again whether he is certain that it is nothing dangerous, and he confirms this. Mother and child leave triage, and Nurse Joachim completes his documentation.

Both of the nurses in this example had worked in the EPCC for more than three years, thus indicating that boundary-blurring was correlated with experience in triage. Their decision making was clearly at odds with the MTS, which states that patients with these symptoms and signs should be registered to see a physician. Instead, the nurses engaged de facto in consultation with the patient, making a diagnosis (in all but the formal sense of communicating it in the triage note) and recommending treatment in the form of non-prescription painkillers and ointments. In so doing, their actions clearly traversed the triage nursing-medical boundary as articulated in this EPCC.

Nurses' main reason for engaging in this boundary-blurring work was to ensure more accurate prioritisation of patients. This was a particularly salient concern when the clinic was (over)crowded and they had to sort a large group of patients according to fine-grained clinical needs. If a critically ill patient was overlooked under these circumstances, $\mathrm{s} /$ he might have to wait for hours before seeing a physician; conversely, if too many patients were admitted or were assigned unduly urgent triage codes, nurses risked overlooking the most critically ill. These considerations motivated nurses to assess patients in a more thorough and discretionary manner than prescribed by the MTS.

The EPCC's management was not wholly opposed to this practice. While they generally expected nurses to follow the MTS (treating it as 'the norm' for priority setting), nurses were allowed to deviate from the system if they had clinically sound reasons for doing so. Nurses were mainly granted discretion to upgrade patients, assigning a higher triage code than specified by the MTS. Downgrading, on the other hand, was mostly considered unacceptable. However, certain managers seemed to allow nurses some discretion in downgrading as well, especially if they considered the nurse to have sufficient experience. In other words, management accepted (and to some extent expected) some blurring of formal boundaries in triage. This is not to say that all managers expressed equal acceptance; rather, they seemed to draw different boundaries for different nurses in different contexts (thus demonstrating the situated nature of professional boundaries in the 
workplace). Nor does this mean that managers were fully aware of how and to what extent triage nurses blurred boundaries. As triage was spatially separated from the rest of the clinic, managers (and other staff) only learned about these nurses' work by reading their triage notes. As long as nurses' documentation and triage code allocation seemed reasonable to outside actors (especially the coordinators overseeing patient flow and the middle managers who occasionally audited triage notes), they had significant discretion in how they assessed patients.

Given this rough sketch of the content and rationale of nurses' boundary-blurring work, the question, then, is how nurses learned to blur the nursing-medical boundary in this discretionary, physician-like manner.

\subsection{Learning}

In the following, I will show how nurses learned to blur professional boundaries by (1) doing physician-like work; (2) interacting with their colleagues; (3) comparing their own clinical assessments to those of the physician (as codified in the patient record) and (4) using medical reference works to guide their clinical-decision making. As will be made clear, these factors were mutually reinforcing, ensuring a strong blurenabling potential.

\subsubsection{Learning by doing}

We begin by looking at some foundational aspects of nurses' workplace learning, which laid the groundwork for developing more extensive blur-enabling knowledge. This learning was intimately linked to the delegation of medically defined roles to nurses, in which they had to assess patients through a medical lens, oriented towards the identification and treatment of biomedical disease. While this work clearly fell within nurses' jurisdiction, it also afforded opportunities and incentives to increase their clinical knowledge, in turn enabling them to blur jurisdictional boundaries.

To begin, it is useful to consider how nurses developed what they referred to as their 'clinical gaze' ('klinisk blikk', a common Norwegian term used almost always without reference to Foucault). This was characterised as an intuitive, perceptual ability that allows nurses to make quick assessments of whether or not a patient is ill. These tacit judgments were based primarily on visual signs, such as pallor, sweating, freezing, abnormal gait or pain expressions. Despite their use of a metaphor that privileges vision, nurses' judgments also encompassed audible, olfactory and tactile cues, derived from listening to, smelling and touching the patient. All of this information was used to judge patients' 'general condition'-that is, their overall state of health.

Neophyte nurses were afforded opportunities to practise their clinical gaze as soon as they began working in the clinic, especially when assigned the role of receptionist. As the first member of staff to meet patients entering the EPCC, receptionists are responsible for moving the most urgent patients to the front of the queue to see the triage nurse. Receptionist nurses did this by making a swift perceptual judgment of the patient's general condition and asking about their reason for attendance. The need to assess large numbers of patients with a broad range of complaints meant that their 'training material' was both voluminous and varied. Given the large number of patients attending the EPCC, receptionists rarely worked alone, and neophytes could therefore develop their gaze under the guidance of more experienced colleagues. Management recognised the importance of this guidance, as a welldeveloped clinical gaze was considered crucial for this and other roles in the EPCC. For instance, it was widely acknowledged that the ability to identify symptoms and signs described in the MTS required knowledge beyond that codified in the system itself; in fact, this was a key reason why nurses in the clinic were required to have at least one year of EPCC experience before practising triage.

However, beyond enabling them to use the MTS, a well-developed clinical gaze also enabled nurses to deviate from the guideline prescriptions. The nurses argued that their gaze allowed them to perceive nuances that escaped the MTS, either by explicitly noticing additional relevant signs (e.g. pallor, swelling) or by simply getting a 'bad gut feeling', alerting them to upgrade the patient's triage code. By developing their clinical gaze, then, nurses could engage in more discretionary diagnostics than specified by the MTS. In other words, this type of learning allowed them to blur the formal boundary that separated their guideline-based assessments from the discretionary diagnostics of physicians.

Additional learning occurred in the role of triage nurse itself, which opened up further possibilities for engaging in physician-like work. During triage assessments, the nurse is required to record the patient's medical history, as well as collect and assess vital parameters such as pulse, respiratory rate and temperature, and perform examinations such as simple neurological assessments. While most assessments lasted between 4 and $8 \mathrm{~min}$, I observed nurses spending as much as $15 \mathrm{~min}$ on the most ambiguous cases. Triage assessments could therefore be remarkably similar to medical consultations; indeed, Nurse Jonas fittingly referred to the triage nurse as a "physician light" (which he and many other nurses considered a positive label, contrary to those seeking to establish nursing as separate from but equal to medicine (cf. May and Fleming, 1997)).

The large throughput of patients also meant that nurses engaged repeatedly in this physician-like work. On busy days, nurses assessed 40-70 individual patients, familiarizing themselves with a broad array of medical conditions and ways of identifying these. Repeated assessments also helped nurses to internalise the MTS flowcharts, turning these into a stable reference point that they could build on, complement and adjust to the particular case being assessed. In this sense, the MTS served what one instructor referred to as a "competence-enhancing function", illustrating how "procedural standards afford an increase in the overall complexity of health care providers' work" (Timmermans and Berg, 2003, p. 64). In combination with the learning mechanisms described in below, this repeated engagement in physician-like work had significant blur-enabling potential.

\subsubsection{Collegial interaction - a community of practice}

Another way in which nurses learned to blur the nursing-medical boundary was by interacting with their colleagues. Different interactions were seen to entail different learning opportunities. In triage, for example, nurses occasionally telephoned the nurse or physician coordinator to confer about patients with ambiguous complaints, sometimes leading to discussions of medical topics such as the likelihood of a particular diagnosis. Triage nurses could also interact with each other; with the exception of night shifts, there were always two nurses performing triage in neighbouring booths. This enabled nurses to doublecheck their diagnostic suspicions, as in the introductory example above, when the two nurses concluded that the patient had chickenpox. Such interactions are likely to increase nurses' diagnostic confidence, as "[a] pproval from colleagues helps to reinforce a sense of personal competence" (Tjora, 2000, p. 735). These episodes are also likely to enhance nurses' diagnostic abilities; for instance, the nurses in the introductory example would be more likely to identify chickenpox on next encountering a patient with similar symptoms. In this way, nurses can collaboratively foster their clinical gaze by helping each other develop "tacit, embodied knowledge of how to 'see' and 'what to look for" (Atkinson, 1995, p. 68).

In other roles, nurses had further opportunities for interacting with colleagues, especially when working 'inside' the clinic, where 7-10 nurses and physicians would share a work station. This enabled ongoing informal exchange of clinical knowledge, as in the following example.

Nurse Benedicte comes over to Nurse Kari and comments that one of the patients has neck stiffness. Kari asks whether she has neck stiffness or a stiff neck [a salient distinction in Norwegian medical jargon]. They discuss this for a while to determine the 
characteristics of the former. Benedicte mentions a training session in which they got to feel neck stiffness in a patient. Nurse Kari comments "How cool!" before I ask her what they might fear if a patient presented with neck stiffness. "Meningitis", she answers. Benedicte then walks over to a physician to ask about the defining characteristics of neck stiffness and discusses this for a while with the physician while Kari listens in. Kari then turns to me and says, "That's the best part of sitting here-being able to listen in when they confer with each other".

This example illustrates the fluid sharing of clinical knowledge between workers in the EPCC. First, the nurses tried to determine the characteristics of neck stiffness-a possible sign of meningitis-before conferring with the physician to settle the matter. Nurse Kari's remark also illustrates how she valued being able to listen in on clinical discussions. Several nurses identified this as a significant benefit of working in the same space as physicians, and especially in proximity to the physician coordinator, who conferred regularly with junior physicians.

Nurses were also well positioned to learn more practical skills when assisting in physicians' consultations-for instance, by exposing them to interview questions and examination methods that could be used during triage assessments. Similarly, when working in the EPCC's medical communication centre, nurses reported that they learned interview questions by listening in on the calls they transferred to the ambulance services. In short, these practices illustrate how nurses could acquire clinical skills by mimicking their colleagues.

Additional learning opportunities open up as nurses ascend the EPCC's formal hierarchy. For example, a nurse coordinator supervises the clinic's patient flow in tandem with a physician coordinator, and the two frequently deliberate on the relative priority of patients who had been triaged, granting the nurse insights into (and engagement with) the physician's medical judgment.

These interactions illustrate how inter-professional cooperation facilitates the flow of blur-enabling knowledge between members of the respective professions. In theoretical terms, nurses and physicians are members of an inter-professional community of practice (Lave and Wenger, 1991)—a group of people "who share a concern, a set of problems, or a passion about a topic, and who deepen their knowledge and expertise in this area by interacting on an ongoing basis" (Wenger et al., 2002, p. 4). Clearly, this was not an egalitarian community; the possibilities for legitimate participation were inter- and intra-professionally stratified, as is typical in complex healthcare organisations (Goodwin et al., 2005). Nevertheless, EPCC workers shared concerns in assessing and handling patients, and regular interactions deepened their knowledge of these tasks.

As we have seen, this community was predicated in part on the particular 'time-space geography' (Walby and Greenwell, 1994) of the clinic. Unlike many hospitals, this EPCC assigned nurses and physicians to the same physical space; and as these nurses and physicians were permanent employees, this entailed ongoing interaction over time among the same set of individuals. Among other things, this meant that experienced staff had a strong incentive to enhance the clinical competence of their less experienced colleagues, as this would enhance the performance of the unit as a whole. Thus, in contrast to other findings that inter-professional relations are characterised by conflict and differing viewpoints (cf. Allen, 1997; Walby and Greenwell, 1994), I observed a more collaborative work setting, aligning with Carmel (2006b) and Liberati (2017). As members of this integrated community of practice, nurses could continue to develop their clinical knowledge, which in turn supported boundary-blurring work in triage and other nursing roles in the EPCC.

\subsubsection{Electronic patient records: indirect feedback}

Workplace assimilation was also facilitated by triage nurses' use of the electronic patient records (EPRs) written by the EPCC's physicians.
A typical patient record was approximately 100 words long and included a brief description of the patient's problem, examination and test results, background information of relevance and the physician's overall thoughts about diagnosis and treatment.

When shadowing nurses in triage, I regularly observed them reading patient records, especially towards the end of their shift-a practice made possible by how EPRs escape the temporal and spatial limitations of paper-based records. Nurses explained that they only accessed the records of patients they had themselves assessed. Their reasons for doing so are hinted at in the following field note excerpt.

Nurse Sara opens the EPR of a female patient with a nut allergy that she assessed earlier and comments that she has been given a lot of medication. Sara explains that the patient looked pretty okay when she assessed her and that this shows how rapidly an allergy can develop. She adds that patients with nut allergies are the scariest, as they can deteriorate rapidly. She then opens the EPR of another of her patients, who presented with abdominal pains and whom the physician has diagnosed as a suspected cardiac infarction. She comments that she had a bad feeling about this one, which was confirmed by reading this record.

This excerpt illuminates how nurses accessed patient records to follow up on patients' development post-triage. This practice enabled nurses to learn how physicians assessed patients they had themselves assessed. In the words of another nurse, Hilde, this allowed them to see "whether you've been thinking along the right lines, and whether you've missed something", which reveals both how nurses viewed their assessments as similar yet subordinate to those of physicians and, more importantly, how reading these records provided nurses with indirect feedback on their own triage assessments.

The assimilative potential of this feedback should not be underestimated. Other studies have noted how EPRs give nurses easier access to the physician's patient documentation as compared to paper-based records, and how this facilitates a less hierarchical relationship between nurses and physicians (Håland, 2012; Svenningsen, 2004). In light of nurses' physician-like work in triage, patient records have even greater potential for producing boundary-blurring effects. Access to EPRs enables nurses to compare their assessments to those of physicians, furthering their understanding of what information to collect, which examinations to perform and what diagnostic category and medications are relevant for patients they have just assessed. This type of feedback is an essential component in the development of expertise, as learning whether one was right or wrong is likely to improve the precision of one's future assessments (Hogarth, 2010; Shanteau, 1992). Furthermore, congruence between the assessments of nurses and physicians is likely to reassure the former, as in the above excerpt where Nurse Sara received 'confirmation' of her diagnostic suspicion. This indirect approval seemed to boost nurses' confidence and can be viewed as a form of "training for certainty" (Atkinson, 1984), encouraging nurses to trust and act on their own inclinations. By enabling a more discretionary approach to the MTS, this process could further facilitate the blurring of boundaries between triage nurses and physicians.

Before turning to the final learning factor, it is worth noting that nurses viewed their use of EPRs as a legal grey area, as the following extract suggests.

Nurse Marit is reading patient records. I ask whether this is something she often does, and she replies: "I sneak in to see whether I've assessed them correctly. I don't know if it's legal, but I do it to get some sort of feedback". I express understanding. "But actually, it's a breach of confidentiality", she adds. I ask whether this is the case even if she assessed the patient herself. "No, that's my reasoning too. But if you just open the record of someone with vaginal haemorrhage or something, just to have a look, then it's not okay." She adds that in [another EPCC], you have to enter a reason before opening a patient record. 
Nurse Marit's comments reveal how this practice was viewed as a potential threat to patients' right to privacy, although not substantial enough to prevent her from engaging in said practice. The commonly held view was that the benefits of learning outweigh privacy concerns, especially when a patient presents with problems that nurses find challenging to assess. Marit's final remark is also noteworthy, as it demonstrates how the potential for workplace learning can vary according to organisational policy and technical solutions.

\subsubsection{Referencing theory in practice}

A final source of blur-enabling knowledge was the plethora of medical reference works available to nurses in triage and elsewhere. Along with courses nurses had to attend at the clinic, where they were occasionally told about diagnostic markers and treatments for different conditions, these reference works were an institutional expression of nurses' need for medical knowledge in their work. As most reference works were in digitized form, they were easily available wherever nurses had access to a computer.

The assimilative potential of these reference works seemed greatest when used in tandem with practical assessments. When nurses performed triage, I occasionally observed them consulting these sources to read about symptoms, signs and treatments associated with particular diagnoses. For instance, consider Nurse Sofie's interaction with a patient who claimed to have shingles (an acute infectious disease that may cause a painful and blistered rash; also referred to as 'herpes zoster').

Patient: I think I've got shingles.

Sofie: Okay, what symptoms do you have?

Patient: I have a burning spot on the top of my head. So that's what I think it is. I'm starting to get a stiff neck too.

Sofie: Have you looked at ... [the spot]?

Patient: No, but my children have.

Sofie goes over to look at the patient's scalp.

Sofie: How long have you been having this?

Patient: Just started today.

Sofie: Have you had it before?

Patient: No.

Sofie: Can you manage to put your chin down towards your chest?

Patient: Yes. (She puts her chin down.)

Sofie opens the browser on her computer and googles 'shingles'. She reads about the condition on Norsk Helseinformatikk [an official Norwegian webpage for healthcare professionals]. She then googles 'shingles treatment' and enters the webpage of a Norwegian pharmacy. In total, she spends three minutes reading about the condition.

[The rest of the interaction has been edited out. In short, Sofie asked the patient about additional symptoms and previous diseases, before turning to a colleague to ask for help. In total, the assessment took eight minutes.]

After the patient has left triage, Sofie explains: "I thought it was a bit strange because I've never triaged anyone with shingles before. In these cases, I occasionally check the treatment [of the condition]. Often, there's no treatment; you're just supposed to wait and let it heal itself, and then I don't bother to register them because there's no use letting them sit here and wait".

This example illustrates how nurses can acquire theory in practice by being probed about particular conditions and then referencing authoritative medical sources for propositional knowledge about these conditions. In this way, her use of the reference works was intimately linked to being delegated physician-like work.

This extract also demonstrates how nurses may incorporate newly acquired knowledge into their discretionary judgment. As Nurse Sofie said, had she discovered that there was no treatment for shingles, she would have been inclined not to register the patient because "then there's no use letting them sit here and wait"-even though, according to the MTS, the patient should be registered. As Sofie and other nurses saw it, knowledge of conditions and treatments might enable them to anticipate the physician's diagnostic and prescriptive conclusions, at least when dealing with relatively simple cases. In situations where they were convinced that their agency was similar to a physician's, nurses were likely to act $a$ s if they were the physician, especially when faced with problems deemed non-urgent and non-treatable. Through this kind of learning and subsequent practice, nurses could significantly blur the boundary between themselves and the EPCC physicians.

\section{Discussion and concluding remarks}

In attempting to elaborate Abbott's (1988) concept of workplace assimilation, this article has explored how nurses learned to blur the nursing-medical boundary in a Norwegian EPCC. Nurses were found to develop blur-enabling knowledge by (1) doing physician-like work; (2) interacting with their colleagues; (3) comparing their own clinical assessments to physicians' assessments as codified in the patient record and (4) using medical reference works to guide their clinical-decision making. It is worth noting that several of these learning mechanisms have been documented as salient aspects of the training of medical interns; for instance, Kivle (2008) has shown how Norwegian interns learn by reading patient records written by senior colleagues. Although far from exhaustive, these findings further our understanding of how workers can develop blur-enabling knowledge in the workplace, in turn facilitating a deeper understanding of the 'fuzziness' of workplace jurisdiction.

Generalising from the case in question, one may expect some degree of workplace assimilation in all settings where members of one occupational group find it relevant to acquire the available tacit or explicit knowledge commonly assumed to be the exclusive preserve of another group. More specifically, structural facilitators of workplace assimilation in this EPCC seemed to include the following. (1) Being delegated work tasks from a superordinate profession, which, together with (2) the turbulent nature of emergency work, incentivised nurses to increase their clinical knowledge; (3) assessing a large number of patients presenting with a broad array of complaints, which provided nurses with varied learning material; (4) having almost unrestricted digital access to EPRs and reference works, which provided nurses with relevant input and feedback on their assessments; (5) being part of an interprofessional community of practice, which facilitated the informal sharing of knowledge; and (6) working closely with physicians, which allowed nurses to access "restricted areas, opportunities and experiences" (Goodwin et al., 2005, p. 860), in which they are "exposed to the very skills, knowledge, and experience that physicians claim to hold exclusively" (Apesoa-Varano, 2013, p. 340). Furthermore, (7) most of this learning was allowed, and to a large extent encouraged, by the clinic's management; and (8) the identity of 'competent clinician' was clearly considered prestigious among clinical workers in the EPCC, further motivating them to increase their clinical proficiency. Although more research is needed to determine the relative weight, exhaustiveness and transferability of these factors, they serve as reference points for further inquiry into how, why and where workplace assimilation occurs.

These findings also help refine our understanding of the 'assimilative' aspect of workplace assimilation. First, nurses' assimilation was not total, as their workplace learning reduced rather than eradicated epistemic differences between themselves and the physicians. This is consistent with Abbott's (1988, p. 65) claim that workplace assimilation provides only a craft version of another profession's knowledge system. 
However, the designation 'craft' may have some unfortunate connotations, especially if interpreted as antithetical to more theoretical forms of knowledge. As we have seen, workplace assimilation within the EPCC also included nurses acquiring clinical knowledge of the abstract, propositional kind. Abbott's 'craft' qualifier should therefore be interpreted in a pragmatic sense (cf. Heritage, 1984, pp. 61-3), i.e. as an emphasis on workplace assimilation being intimately linked to the solving of practical problems, some of which require more in-depth theoretical knowledge.

Developing this 'craft' knowledge can significantly increase workers' agency in the workplace, sometimes beyond that of (some of) their superordinates. As Abbott (1988, p. 66) argued, "the best of the subordinates often excel the worst of the superordinates; certain individuals in closely related professions end up knowing far more about a profession's actual work than do a fair number of its own practitioners". Although I can draw no firm conclusions about the relative proficiency of nurses and physicians in this EPCC, my fieldwork undoubtedly suggests that workplace assimilation was of crucial importance in increasing the accuracy of nurses' triage assessments, allowing them to 'correct' the MTS and to facilitate patient flow during periods of (over)crowding (see also Nugus et al., 2013). This is not to say that all boundary-blurring work rested on an equally sound foundation, or that all nurses were equally competent to blur boundaries. The point is rather that workplace assimilation generally increased the quality of nurses' work.

However, despite its enhancing effects on workers' competence, workplace assimilation does not automatically result in formal jurisdictional change. Knowledge developed on the job is typically still considered subordinate to professional schooling, and overly assimilated workplaces tend to be characterised as "shady" or "unethical" (Abbott, 1988, p. 67). Consequently, management has an interest in downplaying the blurring of professional boundaries, especially in communicating with outside actors. This is not to say that formal change never occurs; Abbott (1988, p. 68) cites the psychotherapeutic revolution in the US as a prime example of how assimilation can intrude into the formal jurisdictional system. There were also some signs of formal recognition in this EPCC, as management had recently extended triage nurses' responsibilities to include questionnaire-based diagnosis of 'simple' urinary tract and eye infections and dispensing non-prescription medicines for pain and allergies. While the relationship between workplace assimilation and formal jurisdictional change is beyond the scope of the present investigation, future research should look more closely at this issue.

In closing, it might prove helpful to see how workplace assimilation extends beyond the relationship between nurses and physicians. Consider, for instance, the EPCC's security guards, who were positioned next to receptionists in the registration area. As the longest-serving group in the clinic, the security guards had significant experience of informally assessing patients. Clinical staff often lauded them for their well-developed clinical gaze, and I occasionally observed guards rushing to help those they identified as being at risk. It was also apparent that the guards regularly contributed to the training of neophyte receptionist nurses, just as other studies have shown that nurses informally train physicians (cf. Xyrichis et al., 2017). This points to more complex networks of training that can fruitfully be explored in future studies of workplace assimilation. It would also be interesting to investigate boundaries, blurring and learning in different settings and across different occupational groups, and the many consequences such learning may have for occupational power relations at micro, meso and macro levels. As such inquiries can provide deeper insights into the dynamics of workplace boundaries, they are highly encouraged.

\section{Acknowledgements}

I would like to thank Dag Album, Erik B. Rasmussen, Marte Mangset, colleagues in my research group at the Centre for the Study of
Professions and my anonymous reviewers for their comments and suggestions.

\section{References}

Abbott, A., 1988. The System of Professions: an Essay on the Division of Expert Labor University of Chicago Press, Chicago.

Allen, D., 2001. Narrating nursing jurisdiction: "atrocity stories" and "Boundary-Work". Symbolic Interact. 24, 75-103. https://doi.org/10.1525/si.2001.24.1.75.

Allen, D., 1997. The nursing-medical boundary: a negotiated order? Sociol. Health Illness 19, 498-520. https://doi.org/10.1111/j.1467-9566.1997.tb00415.x.

Annandale, E., Clark, J., Allen, E., 1999. Interprofessional working: an ethnographic case study of emergency health care. J. Interprof. Care 13, 139-150. https://doi.org/10. 3109/13561829909025546.

Apesoa-Varano, E.C., 2013. Interprofessional conflict and repair: a study of boundary work in the hospital. Socio. Perspect. 56, 327-349. https://doi.org/10.1525/sop. 2013.56.3.327.

Atkinson, P., 1995. Medical Talk and Medical Work: the Liturgy of the Clinic. Sage, London.

Atkinson, P., 1984. Training for certainty. Soc. Sci. Med. 19, 949-956. https://doi.org/10 1016/0277-9536(84)90324-1.

Butler, C.W., Danby, S., Emmison, M., Thorpe, K., 2009. Managing medical advice seeking in calls to Child Health Line. Sociol. Health Illness 31, 817-834. https://doi. org/10.1111/j.1467-9566.2009.01179.x.

Carmel, S., 2006a. Boundaries obscured and boundaries reinforced: incorporation as a strategy of occupational enhancement for intensive care. Sociol. Health Illness 28 , 154-177. https://doi.org/10.1111/j.1467-9566.2006.00486.x.

Carmel, S., 2006b. Health care practices, professions and perspectives: a case study in intensive care. Soc. Sci. Med. 62, 2079-2090. https://doi.org/10.1016/j.socscimed. 2005.08.062.

Ellström, P.-E., 2011. Informal learning at work: conditions, processes and logics. The SAGE Handbook of Workplace Learning 105-119.

Emerson, R.M., Fretz, R.I., Shaw, L.L., 2011. Writing Ethnographic Fieldnotes. University of Chicago Press, Chicago.

Eraut, M., 2004. Informal learning in the workplace. Stud. Cont. Educ. 26, 247-273. https://doi.org/10.1080/158037042000225245.

Evans, L., Honold, K., 2007. The division of expert labour in the European audit market: the case of Germany. Crit. Perspect. Account. 18, 61-88. https://doi.org/10.1016/j. cpa.2005.03.011

Goodwin, D., Pope, C., Mort, M., Smith, A., 2005. Access, boundaries and their effects: legitimate participation in anaesthesia. Sociol. Health Illness 27, 855-871. https:// doi.org/10.1111/j.1467-9566.2005.00477.x.

Håland, E., 2012. Introducing the electronic patient record (EPR) in a hospital setting: boundary work and shifting constructions of professional identities. Sociol. Health Illness 34, 761-775, https://doi.org/10.1111/j.1467-9566.2011.01413.x.

Heritage, J., 1984. Garfinkel and Ethnomethodology. Polity Press, Cambridge.

Hogarth, R.M., 2010. Educating Intuition. University Of Chicago Press, Chicago.

Hughes, D., 1988. When nurse knows best: some aspects of nurse/doctor interaction in a casualty department. Sociol. Health Illness 10, 1-22. https://doi.org/10.1111/14679566.ep11340102.

Illeris, K., 2011. Workplaces and learning. In: Malloch, M., Cairns, L., Evans, K., O'Connor, B.N. (Eds.), The SAGE Handbook of Workplace Learning. Sage, London, pp. 32-45.

Johannessen, L.E.F., 2017. Beyond guidelines: discretionary practice in face-to-face triage nursing. Sociol. Health Illness 39, 1180-1194. https://doi.org/10.1111/1467-9566. 12578.

Johannessen, L.E.F., 2016. How triage nurses use discretion: a literature review. Prof. Prof. 5. https://doi.org/10.7577/pp.1446.

Kirkpatrick, I., 1999. Workplace assimilation and conflict in professional service organisations: the case of university libraries. Publ. Pol. Adm. 14, 71-86. https://doi.org/ 10.1177/095207679901400406.

Kivle, B.M.T., 2008. Å lære og å praktisere i sykehus - turnuslegen som student og lege. Sosiol. Tidsskr. 16, 107-126.

Lave, J., Wenger, E., 1991. Situated Learning: Legitimate Peripheral Participation. Cambridge University Press, Cambridge.

Liberati, E.G., 2017. Separating, replacing, intersecting: the influence of context on the construction of the medical-nursing boundary. Soc. Sci. Med. 172, 135-143. https:// doi.org/10.1016/j.socscimed.2016.11.008.

Mackway-Jones, K., Marsden, J., Windle, J., Manchester Triage Group, 2014. Emergency Triage, third ed. Wiley, Chichester.

May, C., Fleming, C., 1997. The professional imagination: narrative and the symbolic boundaries between medicine and nursing. J. Adv. Nurs. 25, 1094-1100. https://doi. org/10.1046/j.1365-2648.1997.19970251094.x.

Nancarrow, S.A., Borthwick, A.M., 2005. Dynamic professional boundaries in the healthcare workforce. Sociol. Health Illness 27, 897-919. https://doi.org/10.1111/j 1467-9566.2005.00463.x.

Nicolini, D., 2012. Practice Theory, Work, and Organization: an Introduction. Oxford University Press, Oxford.

Nugus, P., Forero, R., McCarthy, S., McDonnell, G., Travaglia, J., Hilman, K., Braithwaite, J., 2013. The emergency department "carousel": an ethnographically-derived mode of the dynamics of patient flow. Int. Emerg. Nurs. https://doi.org/10.1016/j.ienj. 2013.01.001.

O'Cathain, A., Sampson, F.C., Munro, J.F., Thomas, K.J., Nicholl, J.P., 2004. Nurses' views of using computerized decision support software in NHS Direct. J. Adv. Nurs. 45, 280-286. https://doi.org/10.1046/j.1365-2648.2003.02894.x. 
O'Connor, L., 2009. Information literacy as professional legitimation: the quest for professional jurisdiction. Libr. Rev. 58, 272-289. https://doi.org/10.1108/ 00242530910952828 .

Polanyi, M., 1967. The Tacit Dimension. Doubleday, Garden City.

Porter, S., 1991. A participant observation study of power relations between nurses and doctors in a general hospital. J. Adv. Nurs. 16, 728-735. https://doi.org/10.1111/j. 1365-2648.1991.tb01731.x.

Prowse, M., Allen, D., 2002. "Routine" and "emergency" in the PACU: the shifting contexts of nurse-doctor interaction. In: Allen, D. (Ed.), Nursing and the Division of Labour in Healthcare. Palgrave Macmillan, Basingstoke.

Purc-Stephenson, R.J., Thrasher, C., 2010. Nurses' experiences with telephone triage and advice: a meta-ethnography. J. Adv. Nurs. 66, 482-494. https://doi.org/10.1111/j. 1365-2648.2010.05275.x.

Salhani, D., Coulter, I., 2009. The politics of interprofessional working and the struggle for professional autonomy in nursing. Soc. Sci. Med. 68, 1221-1228. https://doi.org/ 10.1016/j.socscimed.2009.01.041.

Shanteau, J., 1992. Competence in experts: the role of task characteristics. Organ. Behav. Hum. Decis. Process., Experts and Expert Syst. 53, 252-266. https://doi.org/10 1016/0749-5978(92)90064-E.

Snelgrove, S., Hughes, D., 2000. Interprofessional relations between doctors and nurses: perspectives from South Wales. J. Adv. Nurs. 31, 661-667. https://doi.org/10.1046/ j.1365-2648.2000.01321.x.

Stein, L.I., 1967. The doctor-nurse game. Arch. Gen. Psychiatr. 16, 699-703. https://doi. org/10.1001/archpsyc.1967.01730240055009.

Stein, L.I., Watts, D.T., Howell, T., 1990. The doctor-nurse game revisited. N. Engl. J. Med. 322, 546-549. https://doi.org/10.1056/NEJM199002223220810.

Svenningsen, S., 2004. Den Elektroniske Patientjournal Og Medicinsk Arbejde. Handelshøjskolens forlag, Copenhagen.
Svensson, R., 1996. The interplay between doctors and nurses-a negotiated order perspective. Sociol. Health Illness 18, 379-398. https://doi.org/10.1111/1467-9566. ep10934735.

Timmermans, S., Berg, M., 2003. The Gold Standard: the Challenge of Evidence-based Medicine and Standardization in Health Care. Temple University Press, Philadelphia, $\mathrm{Pa}$.

Timmermans, S., Epstein, S., 2010. A world of standards but not a standard world: toward a sociology of standards and standardization. Annu. Rev. Sociol. 36, 69-89. https:// doi.org/10.1146/annurev.soc.012809.102629.

Timmermans, S., Tavory, I., 2012. Theory construction in qualitative research from grounded theory to abductive analysis. Socio. Theor. 30, 167-186. https://doi.org/ $10.1177 / 0735275112457914$

Tjora, A., 2000. The technological mediation of the nursing-medical boundary. Sociol. Health Illness 22, 721-741. https://doi.org/10.1111/1467-9566.00228.

Tolich, M., 2004. Internal confidentiality: when confidentiality assurances fail relational informants. Qual. Sociol. 27, 101-106. https://doi.org/10.1023/B: QUAS. $0000015546.20441 .4 a$

Tynjälä, P., 2008. Perspectives into learning at the workplace. Educ. Res. Rev. 3, 130-154. https://doi.org/10.1016/j.edurev.2007.12.001.

Vassy, C., 2014. Emergency departments. In: The Wiley Blackwell Encyclopedia of Health, Illness, Behavior, and Society. John Wiley \& Sons.

Walby, S., Greenwell, J., 1994. Medicine and Nursing: Professions in a Changing Health Service. Sage, London.

Wenger, E., McDermott, R., Snyder, W.M., 2002. Cultivating Communities of Practice. Harvard Business Review Press, Boston.

Xyrichis, A., Lowton, K., Rafferty, A.M., 2017. Accomplishing professional jurisdiction in intensive care: an ethnographic study of three units. Soc. Sci. Med. 181, 102-111. https://doi.org/10.1016/j.socscimed.2017.03.047. 


\section{Article 3}

Johannessen, L.E.F. (2018). Narratives and gatekeeping: Making sense of triage nurses' practice. Published online ahead of print in Sociology of Health \& Illness. 



\section{Narratives and gatekeeping: making sense of triage nurses' practice Lars E.F. Johannessen}

Centre for the Study of Professions, OsloMet - Oslo Metropolitan University, Norway

Abstract It is well documented that emergency service staff consider some patients to be 'inappropriate attenders'. A central example is 'trivia', denoting patients with medical problems considered too 'trivial' to warrant attention. Although research has repeatedly shown that frontline staff violate guidelines in turning away 'trivial' patients, existing research has paid insufficient attention to why staff are willing to engage in guideline-violating gatekeeping, which may put both themselves and 'trivial' patients at risk. To address this issue, the present article explores nurses' narratives about 'trivial' patients - referred to in this context as 'GP patients' - drawing on fieldwork data from a Norwegian emergency service. The article reconstructs three narrative clusters, showing that nurses' gatekeeping is motivated by concerns for the patient being turned away, for nurses and more critically ill patients, and for the service they work for. Some of the issues embedded in these narratives have been under-analysed in previous research most importantly, the role of identity and emotion in nurses' gatekeeping, and how patient narratives can function as 'social prognoses' in nurses' assessments. Analysis of these narratives also reveals an antagonistic relationship between nurses and 'trivial' patients that contradicts nurses' ethical guidelines and indicates a need for healthcare reform.

Keywords: gatekeeping, guidelines, inappropriate attenders, narratives, rationing, triage

\section{Introduction}

Walk-in emergency medical services (EMS) are open to anyone seeking medical attention. This openness attracts people with a wide range of complaints and motivations, many of whom are deemed 'inappropriate' by EMS workers. Staff notions of inappropriateness have been thoroughly investigated in sociological research, particularly in studies relating to informal patient categorisation in EMS settings (Dingwall and Murray 1983, Dodier and Camus 1998, Edwards and Sines 2008, Edwards 2007, Guttman et al. 2001, Hillman 2007, 2014, 2016, Hughes 1977, 1980, 1988, 1989, Jeffery 1979, Kelly and May 1982, Latimer 1997, 1998, Mannon 1976, Roth 1971, 1972, Roth and Douglas 1983, Vassy 2001, Wamsiedel 2016).

A key category explored in this research is 'trivia', which denotes patients presenting with medical problems deemed too 'trivial' to warrant emergency attention. On the surface, 'trivia' might seem a purely clinical category, but existing studies have shown that these patients are judged by an amalgam of clinical and extra-clinical criteria. Such patients are seen to exploit 


\section{Lars E.F. Johannessen}

EMS organisations for reasons of convenience (Vassy 2001), and to present with 'routine' conditions that do not allow staff to utilise their professional skills (Dingwall and Murray 1983, Dodier and Camus 1998, Palmer 1983, Roth 1972). They are further seen to lower the status of EMS organisations to that of GP services (Jeffery 1979) and to deviate from the norm that patients 'should be restricted in their reasonable activities by the illnesses they report with' (Jeffery 1979: 101).

Staff have also been shown to turn 'trivial' patients away altogether from the EMS. Vassy (2001: 619) refers to such gatekeeping as 'the micro-rationing of care', defined as 'when the staff refuse to provide a service which they could competently provide, and when the re-directed person does not obtain the equivalent service elsewhere'. In most of the described settings, turning away patients with medical complaints contravenes organisational guidelines and/or national legislation (cf. Vassy 2001). As those turned away might prove to be sicker than assumed by staff, this is a potentially risky practice for both patient and provider.

Although existing research has highlighted how EMS staff perceive and sanction these patients, the category of 'trivial' patients remains under-analysed in sociological research. Previous studies have largely treated 'trivia' as one among several categories of inappropriate attenders, giving only brief and general remarks about why staff view these patients in this way. Existing research has also neglected why EMS staff are willing to overrule guidelines to turn such patients away. We therefore lack important insight into the logics of their gatekeeping practice.

This article seeks to uncover EMS staffs' subjectively convincing reasons for turning 'trivial' patients away. It does so by analysing the narratives underlying such gatekeeping. As cultural structures of key importance for human cognition and communication (Abbott 2008), narratives have been shown to structure healthcare providers' clinical reasoning (Hunter 1991), and, more importantly, to serve as core heuristics for evaluating the value of patients and their conditions (Johannessen 2014). Narrative analysis is therefore a useful means of untangling staff notions about 'trivial' patients.

Specifically, the article draws its data from a fieldwork study of triage nurses in a Norwegian walk-in EMS organisation. Working in the frontline of the EMS, triage nurses were responsible for assessing the urgency of patients' complaints. Although officially they had very limited authority to deny patients access, they frequently contravened guidelines to turn away 'trivial' attenders, referred to in this context as 'GP patients' (i.e. general practitioner patients). Underpinning their gatekeeping was a series of narratives about GP patients and related elements of their work, all of which reveal salient reasons for engaging in this guideline-violating practice.

In what follows, I elaborate the narrative framework and provide an overview of the study's data and methods. In the analysis, I reconstruct three clusters of narratives, framing gatekeeping as motivated by concerns for: (1) the individual patient; (2) nurses and more critically ill patients; and (3) the EMS as an emergency institution. In conclusion, I discuss the broader implications of these narratives for nurses' gatekeeping practice.

\section{Narratives}

According to Barthes (1975: 237), 'there has never been anywhere, any people without narrative'. His message resonates within the sociology of health and illness, where studies have demonstrated the relevance of narrative in a range of topics related to health and healthcare, including patients' experience of their illness (cf. Frank 1997) and professionals' interpretation of patients (cf. Hunter 1991). 
In the present context, narrative refers to a representation of a series of events (Abbott 2008), chained together by a plot and involving characters acting out or being exposed to these events (Polletta et al. 2011). As representations, narratives simplify characters and events, emphasising some aspects while minimising others. Attending to what and how something is represented therefore serves to highlight how social actors frame and make sense of particular sets of experiences' (Coffey and Atkinson 1996: 67).

Some remarks in previous research on 'inappropriate attenders' hint at the relevance of narrative for understanding patient categorisation and gatekeeping. For instance, Roth (1972: 846) remarked that staff told 'atrocity stories' about patients, but he did not elaborate on content and structure of these stories. Similarly, Jeffery (1979: 95) commented on how the informal categorisation of a patient entailed that 'staff felt able to predict a whole range of features related not only to his medical condition but also to his past life, to his likely behaviour inside the casualty department, and to his future behaviour'. However, like Roth, Jeffery ventured no deeper into this narrative landscape.

The present article explores narratives in an organisational setting, where storytelling 'hardly follows the traditional pattern of a narrator telling a story from the beginning to the end in front of an enchanted and attentive audience' (Czarniawska 2007: 386). As narratives often function on a connotative level (Thwaites et al. 2002), alluded to only in actors' brief remarks, the analysis seeks to reconstruct hermeneutically the narratives underlying nurses' fragmented accounts - teasing out their notions about themselves, GP patients and others as characters with certain motivations and dispositions, embedded in trajectories with positive or negative outcomes. In so doing, we can hope to understand how nurses conceive of GP patients, and why they believe it is warranted to turn them away from the EPCC.

\section{Data and methods}

The article is based on an ethnographic study of a Norwegian emergency primary care clinic (EPCC; legevakt in Norwegian). EPCCs are heterogeneous institutions ranging from a single physician on call in rural areas to large-scale organisations employing hundreds of workers. Similar to emergency departments (EDs) in other countries (Vassy 2014), ${ }^{1}$ the latter organisations allow patients to walk in at their own discretion. Data in this article are drawn from one of these large-scale organisations, an urban, public EPCC that performed more than 50,000 consultations per year; employed more than 100 nurses and physicians and was open for 24 hours on every day of the week. It was intended for patients with medical rather than surgical complaints and served patients along the whole spectrum of criticality.

A basic overview of the EPCC's patient flow provides useful context for the analysis section. The first to meet patients were the receptionists, who registered patients' bureaucratic details and made brief clinical assessments to identify and move the most urgent patients in front of the line to see the triage nurse. Triage was performed in two booths next to the reception, where nurses called on patients individually. A triage assessment typically lasted 4-8 minutes, during which the nurse would gather a brief medical history, collect vital parameters, perform simple examinations and settle on an urgency level. Triage assessments were regulated using the Manchester Triage System (MTS) - a paper-based system of flowcharts in which relevant symptoms and signs are ranked at five levels of urgency. ${ }^{2}$ After triage, patients deemed eligible were sent to another waiting area 'inside' the clinic, where they were to wait to be called on by a nurse for testing or a physician for a consultation. Each shift also had coordinating nurses and physicians to monitor patient flow. 
I conducted 47 fieldwork sessions at this EPCC between April and December 2015. These were stratified according to shifts, weekdays and roles, and had an average duration of six hours. Twenty sessions were spent shadowing nurses in triage and asking them about their assessments, which enabled me to learn about their gatekeeping in close proximity to actual patients. The other sessions were spent following nurses in other roles, as well as physicians and auxiliary staff. For the purpose of analytical contrast, I conducted a further nine fieldwork sessions at two other emergency institutions.

Important parts of the fieldwork were conducted in non-patient settings, notably in break rooms and at the working station shared by nurses and physicians, which were key places for sharing remarks about GP patients. When several nurses were present, I would mostly listen to their conversations, occasionally asking about topics of interest. When alone with nurses, I would engage them in conversation; on quiet days, these interactions took the form of informal interviews.

I also conducted semi-structured interviews with seven nurses, two physicians and two managers, all recruited towards the end of fieldwork. The interviews with nurses lasted on average 100 minutes (ranging from 40 minutes to three hours). Using an interview guide with seven batteries of questions, I inquired about topics such as 'inappropriate attenders' and gatekeeping in the EPCC.

The interviews were transcribed verbatim. During fieldwork, I scribbled keywords and nearverbatim quotes on a notepad or laptop, for later use in writing more elaborate, low-inference field notes (totalling approximately 1,270 single-spaced pages). All notes were written in Norwegian; I have translated the extracts included in this article, making minor grammatical and aesthetic adjustments.

The study was approved by the Norwegian Social Scientific Data Services. Pseudonyms are used to secure informants' internal and external confidentiality (Tolich 2004), and no other identifying information is disclosed. I signed non-disclosure agreements with the participating EPCCs and secured participants' informed consent by distributing an information letter and delivering several short presentations on the project.

Analysis began immediately on entering the research setting. As nurses were particularly concerned with GP patients, teasing out their notions about this category became a key occupation during fieldwork and in writing field notes. For this article, the relevant data were inductively differentiated and iteratively reviewed to explore nurses' notions about GP patients. I did not begin by analysing narratives but became aware of the narrative character of nurses' perceptions through long-term engagement with the data. As there are no firm boundaries between the reconstructed narratives, I refer to each section in the analysis as a 'narrative cluster', ordered around certain thematic and structural similarities.

In selecting data, I have been careful to emphasise those accounts that were consistent with nurses' gatekeeping practice. Because I was not allowed to record nurses' conversations in the field, most of the quoted excerpts are drawn from the interview data, which are richer in detail and reveal more about how nurses viewed GP patients. However, it is important to note that the analysis builds on all the data collected about GP patients, and that the interviewees' accounts are largely consistent with remarks made in backstage settings. A likely reason for this consistency is that I interviewed nurses towards the end of the fieldwork, after ensuring that they saw me more as 'one of them' than as a potentially dangerous 'outsider'. As Nurse Nina told me in her interview, 'Now that you've been working with us for so long, [...] you've seen it yourself; you know what we're talking about, and you don't respond by raising your eyebrows thinking 'Oh my gosh! Are you a nurse?' 


\section{Analysis}

To begin, it is useful to look at the category 'GP patients' itself, as this was used by the nurses. A first defining feature is that GP patients are those with problems deemed to have a medical (i.e. somatic or psychiatric) rather than a social basis. This is a central distinction within the category of 'illegitimate attenders', separating GP patients from, for instance, the 'tramps' and 'drunks' described by Jeffery (1979). Second, GP patients present with problems that are deemed 'non-urgent' - in other words, they are considered unlikely to be at risk of serious harm if referred to a lower level of care (usually their GP service). Prototypical members of this category included young patients presenting with mild ear pains or a sore throat. However, congruent with other studies (cf. Vassy 2014), the boundary separating urgent from non-urgent was seen to vary according to such factors as number of attenders, time of day, patients' impression management, and the nurse making the assessment.

GP patients were also referred to as 'green' patients, referring to the second lowest level of urgency among the MTS' five triage codes. 'Blue' is the least urgent category, but less than one per cent of patients were assigned to this category, making 'green' the lowest priority de facto. In broad terms, 'green' encompassed all patients who: (1) had experienced changes in their medical condition during the last seven days but (2) had no symptoms or signs indicating a need for medical attention within the next sixty minutes (the target waiting time for the third least urgent code, 'yellow').

Many nurses expressed frustration that management generally considered 'green' patients to be eligible for EPCC treatment. ${ }^{3}$ In both their words and actions, nurses instead insisted on drawing a distinction within the green category. On the one hand were the legitimate 'green' patients who, although having no symptoms suggesting urgency, could benefit from further inquiry (e.g. because of having a somewhat 'diffuse' condition). On the other were the mere 'GP cases', who nurses frequently attempted to turn away from the EPCC. ${ }^{4}$

Of the 342 triage assessments I observed, 120 resulted in a green code while 62 ended in an attempt to turn the patient away. ${ }^{5}$ Fearing sanctions, nurses rarely denied GP patients access; instead, they relied on a series of strategies to convince the patient to go home or to seek help elsewhere. To 'turn a patient away', then, meant trying to convince them to go home and rest, to visit their GP or to visit the other (allegedly 'simpler') EPCC in the city. Approximately 75 per cent of the observed attempts were successful. Although this form of gatekeeping was often 'softer' than the 'micro-rationing' described by Vassy (2001), it was nonetheless at odds with the guidelines. Nurses' reasons for engaging in this practice are explored in the narratives below.

\section{Helping the patient}

A first cluster of narratives framed gatekeeping as a way of helping the patient. These accounts typically related to patients who attended at busy times and who, because of their low-priority triage code, would have to wait several hours before receiving medical attention. Nurse Olivia exemplified this concern as follows:

Sometimes, they get complete sympathy and empathy from me, even if they get a green priority. I mean, I often say it to help the patient, especially when I'm working nights or evenings; then I say 'Perhaps it will be better for you to go home and sleep and contact your GP tomorrow instead, or come back here during the daytime, when there's a shorter line' because I know they're going to be sitting here all night. (Interview) 
This account emphasises Nurse Olivia's concern for the patient's wellbeing. She knows that green patients may have to wait all night and therefore advises them to seek help the following day when there are more available staff. Other nurses offered similar reasons for turning away patients they were certain would receive no effective treatment in the EPCC, or whose condition they believed would benefit from thorough follow-up by their GP.

On occasion, nurses framed this 'helpful' gatekeeping as opposing management's economic interests, as in Nurse Christine's account:

Nursing management wants as many patients as possible in the clinic because this is about money - the more patients we get, the more money we get. And there's a deficit, so they want all the patients they can get. But street-level nurses tend to disagree with that if we can offer them help elsewhere, where the patients may be seen sooner. So, [we're] focusing on the patient, not on the economic aspects.

She went on to recount an example of these differing orientations:

This one time, the head of my division visited the booth where I triaged patients, and then I said [to several patients] 'Go to [the other clinic in the city] because here you have to wait six hours' - we're talking simple stuff, like ear infections, a simple sore throat, some stuffy noses - things like that. And then the head of my division told me 'You can't do that, Christine; they are making us really easy money because they're so quick [to treat]'. And then I tried to say 'But ... you have to consider the patient'; but 'No, that's nothing to be concerned about' [laughs in a resigned manner]. (Interview)

In these accounts, Nurse Christine casts herself in the role of patient's advocate, fighting for the patient's interests against the economic interests of management. Because management's concerns are depicted as extra-clinical, Christine is framed as justified in her clinically grounded 'defiance'.

A central underlying theme in these narratives is nurses' clinical competence. Nurses considered themselves capable of determining patients' eligibility for the EPCC, and of predicting the outcome of the physician's consultation (at least in assessing 'simple' cases). This reveals one salient reason for overruling guidelines: that one considers oneself competent to do so. In this regard, many nurses considered the MTS too risk-averse, arguing that it needed some professional adjustment. ${ }^{6}$ Accordingly, nurses often deemed it necessary to apply stricter criteria than the MTS when guarding the gates to clinic.

Finally, it is worth noting that these stories portray nurses and GP patients as having shared interests. In contrast, the next two sections reveal a more antagonistic relationship between the two groups.

\section{Helping themselves and more critically ill patients}

The second cluster of narratives centred on how admission of GP patients might negatively affect EPCC work. These narratives can be divided into two main types. The first emphasised how GP patients, by their sheer number, impact negatively on nurses' everyday work. This narrative was set against the backdrop of resource scarcity, as the EPCC was much-visited, and nurses often complained about being understaffed and overworked. GP patients were in part blamed for this because they were seen to attend in large numbers with problems that did not warrant nurses' time and attention - in other words, they added unnecessarily to an already challenging workload. A related complaint was that admitting a large number of GP patients could result in loss of oversight and control, potentially placing other patients at risk. Nurse 
Nina explained this when I asked her about the problems of admitting GP patients to the clinic:

When we have a lot of patients, it's easy to lose control - especially of the waiting area. Patients have a responsibility to tell us if they get worse, but this is where things can slip through the cracks. When we're overseeing a lot of patients, the waiting list is long, and a lot of time passes between each check on patients. They may be assigned a low priority [in triage], but that can change during their wait. They could develop criteria for sepsis [blood poisoning], and when there's a lot of patients, we might miss that. (Interview)

Nina's account depicts a possible trajectory where a patient deteriorates in the waiting room while nurses are too busy attending to other (and, implicitly, more trivial) concerns. Her account highlights the fear that certain patients in the lower urgency categories - typically, the 'green' and 'yellow' patients with somewhat 'diffuse' conditions - could be at risk of swift deterioration after leaving triage. The influx of GP patients adds to this concern because their sheer numbers make it more difficult to keep track of each individual patient in the waiting room.

A second type of narrative within this cluster concerned patients' behaviour while waiting especially when the EPCC was overcrowded, as was frequently said to be the case. Crucially, in these stories, GP patients were described as tending to complain or 'nag' during their wait. Nurses often conveyed their irritation with such 'nagging' in brief moments of backstage 'ventilation'. A much-repeated juxtaposition was that 'most complaints come from patients who really don't have to be here' (Nurse Ella). Nurses also expressed frustration with the content of patients' complaints, as in the following declaration by Nurse Olivia:

It would have been different if someone had stopped me saying 'Could you have a look at him, he's experienced a rapid decline', and it actually turned out to be true - right? Instead, they stop you and claim that they've been waiting for five hours when they've really only been waiting one hour. On top of that, they were warned about the wait when they were first registered. (Interview)

Olivia's account highlights an important distinction between asking for a new assessment and complaining about a long wait. The latter was poorly regarded as clinically unwarranted and devoid of any useful information for the nurses, and because it signalled a lack of trust in nurses' assessments (and in the functioning of the EPCC more generally). Her account also emphasises how patients are likely to exaggerate, and how they complain despite having been warned by the triage nurse about the waiting time. Olivia's description is typical of how nurses viewed 'the nagging patient'. In this regard, several nurses confessed to having developed an aversion to the waiting room; one even referred to a colleague who considered quitting the EPCC principally because of constantly having to deal with patients' non-clinical questions.

Beyond being merely irritating, nagging was also said to delay patient treatment. As evidence of this, several nurses referred to the 'vicious cycle' of the waiting room, which Nurse Nina described as follows:

No one gets rejected ${ }^{7}$ here. That means, unfortunately, that there's a long wait for things that aren't critical and that could, in theory, be seen by a GP. A long wait makes the patients frustrated; they become irritated, and then they start complaining about having to wait, and then we spend a lot of our time explaining to them 'This can wait, it's not critical, 
we have to prioritise the sickest patients first'. They're stealing attention from our real work, and after a while, that makes you really resigned. (Interview)

Nina depicts a process in which GP patients become frustrated while waiting, leading to complaints that take up nurses' time and further delay treatment. Additionally, other nurses claimed that 'nagging' in the waiting room was contagious; when one patient begins to complain, others soon follow. Although Nurse Nina attributed this behaviour to GP patients having to wait longer than others, she emphasised the frustration of having to deal constantly with such complaints. Implicit in her account is the belief that all patients are prone to nagging (some more so than others), highlighting one reason for wanting to turn away any patient presenting with GP problems on busy days.

GP patients were also seen to lack respect for the EPCC's functioning. This was exemplified when I asked Nurse Nora about the problems of admitting these patients to the clinic. She first referred to the 'vicious cycle' mentioned above and then recounted the following story:

Nora: I had a patient in Room 5 who was really ill, and then a green one came into the room, asking 'When is it my turn?' That's incredibly rude. Then you don't give a shit about how polite you're supposed to be; it's like, 'Get out! Get out, go to the waiting room and wait until you're called!'

I: $\quad$ So, that has happened to you?

Nora: $\quad$ Yeah, and that pissed me off.

I: $\quad$ What happened?

Nora: I think I saw to someone who wasn't breathing properly, or who was unconscious, and we were working on him in Room 5, and then this person came in and started to nag about having to wait. And when they see the patient in front of them, then you'd expect them to have a basic understanding of 'Okay, they're actually that bad, then I understand why I have to wait'. But when they don't, then ... then you've had it. Sometimes, it's just too much. I've never said anything impolite to patients; I've never called someone an idiot or told them to shut up, but I'm like, 'You have to get out because you have no reason being here! Go out, sit down and behave properly'. We kind of have to resort to adult education sometimes. (Interview)

Nora's story establishes a contrast between the triviality of this 'nagging' patient's complaint and the importance of treating critically ill patients. She emphasised that the patient, even when personally witnessing a life and death drama, failed to recognise why he had to wait. Within this narrative framing, his actions reveal a lack of appreciation for the priorities of EPCC staff. For Nurse Nora, this was particularly evident in how the patient physically entered Room 5 to complain. This room is dedicated to the treatment of the most critically ill patients, and as such represents 'real' emergency medicine to clinic staff. By entering this room, the GP patient disrespected this valued symbol, causing Nora to feel a strong need to sanction his transgression. ${ }^{8}$ It is also worth noting how Nora shifts between describing this particular patient and a more general 'type' - in other words, the patient is treated as a metonym for the moral transgressions of this patient group, as evidence of how 'they' selfishly prioritise their own problems without concern for those in greater need.

In contrast to the previous section, then, these narratives depict the interests of nurses and GP patients as conflicting rather than shared. 'Green' patients complicate EPCC work, both by their sheer presence and by their tendency to complain and disregard highly valued aspects of emergency medicine. These narratives also include concerns for a third 
party, the sicker and more deserving patients, which serves to heighten the triviality of GP patients' complaints.

On busy days, the leap to rationing seems clear. Knowing that GP patients will fill up the waiting room - and that they will have to wait for several hours, leading to 'nagging', interfering with nurses' work and potentially putting sicker patients at risk - nurses see good reason to turn GP patients away from the EPCC.

\section{Helping the EPCC}

The two narrative clusters above concern gatekeeping in an overcrowded setting, where nurses discern a series of reasons for turning GP patients away. On slower days, the threshold for admitting patients was claimed (and observed) to be lower, meaning that more patients were accepted. However, several nurses emphasised the importance of turning away certain patients, regardless of capacity, as in the following assertion by Nurse Olivia:

Sometimes we turn them away because we think they're abusing the clinic - like, they're constantly presenting with a stuffy nose and the like. ${ }^{9}$ So, even when there's a short line, we're sort of doing it on principle.

Later in the interview, she stated the following:

Olivia: Even if there's a short line, if someone presents with a 'green' problem, then I usually try to advise them to seek help from their general practitioner. To ... discourage them from them spreading a rumour, so to speak, that 'if you come to the EPCC, then things move swiftly, without problems'.

I: $\quad$ Do you think people are spreading that kind of rumour now?

Olivia: Yeah, at least within certain groups.

I: What do you think that rumour consists of?

Olivia: Well, say, if you're ... if two friends are chatting, and one of them complains that she has some pain, but that she doesn't want to bother with calling her GP, for instance, then the other might say 'But just go to the EPCC; that's what I did, and it was really efficient, they saw me right away, and ...' I think that's how it often works. (Interview)

Nurse Olivia highlights how nurses may be motivated to turn GP patients away even on slow days, either to sanction repeated presentations with inappropriate complaints or to combat the spread of rumours about the EPCC as convenient. Both motivations are grounded in her belief that many 'green' patients 'abuse' the EPCC - a term that reveals both the negative experience of seeing patients taking advantage of the EPCC and her moral reproach of such actions.

Accusations of 'abuse' were common among the nurses, who often exchanged stories about patients exploiting the constant availability of the EPCC. Nurse Nina gave the following examples of 'abusive' reasons for attendance:

A lot of the patients are honest, or they give themselves away, if I may put it like that, when they come here saying 'My GP's too far away'; they happened to be in the area; they couldn't get an appointment [with their GP] today; they have so much else to do this week, or they don't feel they can take time off work to go to their GP during working hours excuses like that. (Interview) 
Nina's account suggests that many patients are perceived as using the EPCC primarily for convenience, violating the norm of attending only when you cannot wait to receive help elsewhere. Several nurses argued that this defeated the purpose of the EPCC, as in the following field note excerpt:

'It's not EPCC work to do infection tests on people with sore throats, just because they won't bother going to their general practitioner', Nurse Nora says, frustrated. 'Everything about the clinic loses its meaning when people can come here for whatever'. She insists that the EPCC is intended for people with critical illness. 'So the EPCC should be an EPCC?' I probe. She confirms, adding 'But [this EPCC] isn't that - we're the whole city's GP office'. (Lunchroom conversation)

Nora's account reveals how GP patients blur the line between EPCCs and GP services. She articulates this as 'everything EPCC' losing its meaning, which highlights GP patients' status as 'matter out of place' (Douglas 1966: 44) in the EPCC, threatening to break down institutional boundaries. Because EPCCs outrank GP services in the nurses' hierarchy of healthcare organisations, this potential breakdown was considered particularly problematic. EPCCs are seen to have at least the potential for lifesaving and drama, which is generally considered prestigious in healthcare settings (cf. Album et al. 2017). In contrast, nursing in GP services is associated with administrative and routine clinical tasks, often performed by less qualified healthcare assistants. The influx of GP patients therefore risks reducing the EPCC to a 'mere' GP service. A similar notion was implicit in Nurse Nina's criticism of patients using the EPCC as a 'hairdresser with drop-in hours'. While cutting hair is not typically considered a matter of life and death, EPCC work should, in the opinion of many nurses, be exactly this.

Nurses' concerns for the EPCC's institutional identity can be further understood by exploring the connection with narratives referencing 'real' EPCC work - that is, treatment of critically ill patients. In contrast to GP patients, nurses referred to the treatment of critically ill patients as 'exciting' and even 'fun'. Nurse Maya explained this as follows:

With critical cases, we typically get to make quick and major changes. If, say, we're treating someone with acute respiratory problems, in a few minutes, we have kind of saved that life, right? (Interview)

Critically ill patients afford nurses an opportunity to be lifesavers, bringing a patient from certain death to certain survival - a binary reversal that is highly valued in health care. These 'quick and major changes' are exactly the opposite of what GP patients offer staff, as GP patients typically require time-consuming examinations in triage (to ensure that there are no signs of urgency) and the triviality of their complaints precludes any intervention of significance. Further contrasts were established in the following account by Nurse William:

The critical - that's high tempo. It's quick decisions with significant consequences for the outcome. It's more risky. If you're wrong then it might have serious consequences. So, you have to have some ambition when it comes to mastering the trade. And I think that's motivating for those who apply here. You have to know your stuff - you'll quickly be exposed if you don't. When you're working with less critical cases, like fiddling in the lab with some green patients, then you might get away with being at a lower professional level - it won't have any grave consequences. But if it's critical, it will, and then you'll quickly be exposed. Moreover, it's about action - ambulances, sirens, stretchers carried in haste through the corridors. On good days, you might get a sense of life and death, if that's what 
you want. And you have relatives in despair, and it's a lot of emotions in the swing of things. (Interview)

Nurse William echoes Nurse Maya's notion of 'life and death', adding the narrative elements of risk, action, rapid pace and emotional investment - evoking, perhaps, images from TV medical dramas like ER or House. He also emphasises the need for the specialised skills required of characters in such dramas, in explicit contrast to 'green' patients, who are framed in much more mundane terms, affording staff fewer possibilities for professional affirmation. Accordingly, another nurse, Emil, confided, 'Every day, we're hoping it's something real, so we get to do the things we're trained to do rather than just doing trivial routine stuff all the time'.

In this overarching narrative, then, GP patients are depicted first as 'abusing' the EPCC's openness, and second as threatening to break down the institutional boundary between EPCC and GP services. Both were seen as reasons for turning away patients, even on slow days. Regarding 'abuse', it should be noted that there was some disagreement about its prevalence; while some nurses believed that a majority of GP patients were 'abusers', others saw these as a small minority. Nevertheless, most agreed that certain patients abused the clinic, and that these were more deserving of sanction. Accordingly, there was an observed tendency that the more 'abusive' a patient was perceived to be, the more time and energy was invested in guarding the gateway to the clinic.

\section{Discussion and concluding remarks}

Using narrative analysis to untangle nurses' reasons for turning away GP patients, the present analysis has reconstructed three clusters of narratives, which show nurses' guideline-violating gatekeeping to be motivated by concerns for the individual patient turned away, for nurses and more critically ill patients, and for the emergency service in which they work. Nurses were most vocal about the antagonistic narratives in latter two clusters, but all were compatible with observed gatekeeping practice.

As well as resonating with and extending previous findings, the analysis has also highlighted aspects of gatekeeping that have previously received little attention - for example, how turning patients away may be motivated by concern for the patients themselves. ${ }^{10}$ Three additional contributions, intimately linked with the study's narrative perspective, deserve particular mention. First, in focusing on characterisation, the narrative perspective highlights the importance of identity in nurses' gatekeeping practice. ${ }^{11}$ For example, we have seen how the concern for organisational identity was important for nurses seeking to protect the EPCC's role as a place for critically ill patients. Issues of identity were also evident on a personal level, as for instance in nurses' regard for the lifesaving and dramatic aspects of working with critically ill patients. While this potentially cast nurses as heroic figures in a drama of life and death, GP patients were associated with far more mundane imagery. Put simply, their presence was considered a threat to nurses' prestigious identity as lifesavers, augmenting the importance of turning such patients away from the EPCC. Although similar concerns have been documented in research on EDs (cf. Hillman's $(2007,2014)$ discussion of 'real' emergency medicine), this might be a particularly pressing concern for EPCC nurses because of their institutional position between the 'trivia' of GP services and the 'emergencies' of EDs.

Second, the reconstructed narratives illustrate the affective sides of nurses' gatekeeping, echoing Czarniawska's (2007: 390) view that 'stories permit access to the emotional life of organizations'. Among other things, GP patients were seen to evoke feelings of frustration and anger. Considering how people typically want to avoid situations of low 'emotional energy' 
(Collins 2004), this seems likely to reinforce nurses' motivation for turning away GP patients. And as emotions tend to intermesh with notions of patients' social worth (cf. Sointu 2017), this might be a problematic source of social inequality in healthcare delivery.

Third, in addressing temporality, the narrative perspective also helps us see how the reconstructed narratives can serve as social prognoses in nurses' triage assessments. While clinical prognoses are confined to predicting the trajectory of a patient's medical condition, social prognoses entail a broader set of predictions, encompassing the possible consequences not only for the particular patient but also for nurses, for other patients, and for the EPCC more generally. The abovementioned 'vicious cycle' of the waiting room is a key example of such prognoses. In patient assessments, these broader prognoses can serve as hypotheses to be tested against the available data, for instance by considering whether patients' behaviour suggests that they are likely to cause trouble while waiting. In this respect, social prognoses align with Schutz's (1967) work on typification, which demonstrates our general reliance on common-sense constructs of typical motives, personalities and actions in making sense of our social worlds. Although beyond the scope of this article, further research into this connection between prognostication and typification is highly encouraged (for inspiration, cf. Veltkamp and Brown 2017).

In adopting a narrative perspective, this article does not mean to trivialise nurses' concrete experiences with GP patients (who on occasion were observed to behave in accordance with the antagonistic narratives as described above). However, it is important to maintain an analytical distinction between experiences and narratives; the latter are representations, and this has several important implications for interpreting the present findings. First, patients might have been represented differently. For instance, what nurses framed as 'nagging' might instead be seen as a consequence of having to wait while experiencing discomfort and pain. Second, some experiences were emphasised more than others - in particular, atypical or 'extreme' cases attracted greater attention, indicating a bias in nurses' cognition and communication (cf. Kahneman 2011). Third, because nurses shared stories with each other (and often also retold stories heard from others), they prolonged the sense of the original encounters. As this storytelling diffused and cemented beliefs about GP patients, a nurse could have reasons for turning away these patients regardless of whether s/he had had direct personal experience with them. Moreover, the shared nature of these beliefs added significantly to their normative force; as Ridgeway (2014: 5) notes, 'individuals expect others to judge them according to [shared] beliefs' and therefore 'take [them] into account in their own behavior, whether or not they personally endorse them'. ${ }^{12}$ Finally, these shared narratives inevitably informed nurses' experiences with patients in the EPCC, serving as general schema for interpreting individual patients' behaviour (cf. Zerubavel 1997). These are important reasons for highlighting the role of narratives in gatekeeping.

Lastly, the present findings reveal some troubling features of patient-provider relations in EMS organisations, as nurses' antagonistic narratives reveal assumptions, expectations and generalisations that can negatively affect how they receive and treat those identified as GP patients. ${ }^{13}$ However, because the reviewed EMS research has found some degree of antipathy towards 'trivial' patients across time, space and occupational groups, it is important to recognise the structural foundations of this antagonism, rather than simply attributing it to the moral shortcomings of nurses. Relevant structural factors include the tension between openness and emergency-centeredness in walk-in EMS organisations (Dodier and Camus 1998) - and how this is often resolved in favour of the latter, to the potential detriment of EPCCs and other EMS being open, lowthreshold institutions. Furthermore, Hillman (2016) shows how antipathy can be linked to institutional concerns of rationalisation and efficiency, which engender a 'combative' relationship between EMS staff and patients. More - and preferably comparative - research is needed to flesh out the structural determinants of this 'combative' relationship. However, one thing is evidently 
clear: if the 'respect for the life and the inherent dignity of the individual shall characterize all practice' (Norwegian Nurses Organisation 2011: 15), then EMS staff, managers and policy makers must work to reduce this antipathy towards 'trivial' patients.

Address for correspondence: Lars E.F. Johannessen, OsloMet - Oslo Metropolitan University, PB 4 St. Olavs plass, Oslo 0130, Norway.E-mail: Lars.Johannessen@hioa.no

\section{Acknowledgments}

I would like to thank Dag Album, Erik B. Rasmussen, my research group at the Centre for the Study of Professions, the people at Yale University's Center for Cultural Sociology, and my anonymous reviewers for their comments and suggestions.

\section{Notes}

1 In contrast to EPCCs, most Norwegian EDs do not allow patients to walk in at their own discretion.

2 The MTS system is detailed in Mackway-Jones et al. (2014).

3 It should be noted that management permitted nurses to 'advise' the least urgent 'green' patients to seek help elsewhere when higher-ranked coordinators deemed the clinic overcrowded. However, most nurses turned patients away without regard to this centralised coordination.

4 Although staff attempted to turn patients away at several points in the clinic, triage nurses were its main gatekeepers because they were the frontline personnel making the most thorough clinical assessments.

5 I also observed five 'blue' and two 'yellow' patients being turned away (the latter two were allegedly 'overtriaged' by the MTS).

6 Arguably, the triage nurses had good reasons for 'adjusting' the MTS; see Johannessen $(2017,2018)$ for a more thorough discussion.

7 'Rejection' denoted outright denial and was seen as a harder and less legitimate form of gatekeeping.

8 Entering the room of another patient was also considered problematic for other reasons - in particular, because it violated the patient's right to privacy. However, in Nurse Nora's account, the disregard for Room 5 seems the most serious transgression.

9 Nurses had access to the clinic's electronic patient record system and used it regularly to reference patients' EPCC history.

10 Buchbinder (2017) makes a similar argument.

11 As Hillman (2007: 170) suggested, 'Perhaps patient's appropriateness remains to a large extent related to staff identities'.

12 The data suggests that these narratives were shared by many physicians as well as by nurses. Furthermore, some nurses claimed that physicians expected them to be strict gatekeepers. Although I never observed physicians explicitly conveying such expectations, these claims suggest that physicians at least influenced nurses in a Meadian sense, acting as a 'generalised other' (Mead 1934) who was assumed to expect such gatekeeping.

13 Theoretically, it is possible that nurses' antagonistic narratives serve as 'blinders' on their assessments, making them overlook relevant data and turn patients in need of emergency attention away (cf. Kahneman 2011). My data do not suggest such conclusions, but this could be explored in future research.

\section{References}

Abbott, H.P. (2008) The Cambridge Introduction to Narrative. Cambridge: Cambridge University Press. 
Album, D., Johannessen, L.E.F. and Rasmussen, E.B. (2017) Stability and change in disease prestige: a comparative analysis of three surveys spanning a quarter of a century, Social Science \& Medicine, 180, 1, 45-51.

Barthes, R. (1975) An introduction to the structural snalysis of narrative, New Literary History, 6, 2, 237-72.

Buchbinder, M. (2017) Keeping out and getting in: reframing emergency department gatekeeping as structural competence, Sociology of Health \& Illness, 39, 7, 1166-79.

Coffey, A. and Atkinson, P. (1996) Making sense of qualitative data: complementary research strategies. Thousand Oaks: Sage Publications.

Collins, R. (2004) Interaction Ritual Chains. Princeton: Princeton University Press.

Czarniawska, B. (2007) Narrative inquiry in and about organizations. In Clandinin, D. (ed) Handbook of Narrative Inquiry: Mapping a Methodology. Thousand Oaks: Sage Publications.

Dingwall, R. and Murray, T. (1983) Categorization in accident departments: 'good' patients, 'bad' patients and 'children', Sociology of Health \& Illness, 5, 2, 127-48.

Dodier, N. and Camus, A. (1998) Openness and specialisation: dealing with patients in a hospital emergency service, Sociology of Health \& Illness, 20, 4, 413-44.

Douglas, M. (1966) Purity and Danger: An Analysis of Cconcepts of Pollution and Taboo. London: Routledge.

Edwards, B. (2007) Walking in - initial visualisation and assessment at triage, Accident and Emergency Nursing, 15, 2, 73-8.

Edwards, B. and Sines, D. (2008) Passing the audition - the appraisal of client credibility and assessment by nurses at triage, Journal of Clinical Nursing, 17, 18, 2444-51.

Frank, A.W. (1997) The Wounded Storyteller: Body, Illness, and Ethics. Chicago: University of Chicago Press.

Guttman, N., Nelson, M.S. and Zimmerman, D.R. (2001) When the visit to the emergency department is medically nonurgent: provider ideologies and patient advice, Qualitative Health Research, 11, 2, 16178.

Hillman, A. (2007) Negotiating access: practices of inclusion and exclusion in the performance of 'real' emergency medicine. PhD. Cardiff University.

Hillman, A. (2014) 'Why must I wait?' The performance of legitimacy in a hospital emergency department, Sociology of Health \& Illness, 36, 4, 485-99.

Hillman, A. (2016) Institutions of care, moral proximity and demoralisation: the case of the emergency department, Social Theory \& Health, 14, 1, 66-87.

Hughes, D. (1977) Everyday and medical knowledge in categorizing patients. In Dingwall, R., Heath, C., Reid, M. and Stacey, M. (eds) Health Care and Health Knowledge. London: Croom Helm.

Hughes, D. (1980) The ambulance journey as an information generating process, Sociology of Health \& Illness, 2, 1, 115-32.

Hughes, D. (1988) When nurse knows best: some aspects of nurse/doctor interaction in a casualty department, Sociology of Health \& Illness, 10, 1, 1-22.

Hughes, D. (1989) Paper and people: the work of the casualty reception clerk, Sociology of Health \& Illness, 11, 4, 382-408.

Hunter, K.M. (1991) Doctors' Stories: The Narrative Structure of Medical Knowledge. Princeton: Princeton University Press.

Jeffery, R. (1979) Normal rubbish: deviant patients in casualty departments, Sociology of Health \& Illness., 1, 1, 90-107.

Johannessen, L.E.F. (2014) The narrative (re)production of prestige: how neurosurgeons teach medical students to valorise diseases, Social Science \& Medicine, 120, 1, 85-91.

Johannessen, L.E.F. (2017) Beyond guidelines: discretionary practice in face-to-face triage nursing, Sociology of Health \& Illness, 39, 7, 1180-94.

Johannessen, L.E.F. (2018) Workplace assimilation and professional jurisdiction: how nurses learn to blur the nursing-medical boundary, Social Science \& Medicine, 201, 51-8.

Kahneman, D. (2011) Thinking, Fast and Slow. New York: Farrar, Straus and Giroux. 
Kelly, M.P. and May, D. (1982) Good and bad patients: a review of the literature and a theoretical critique, Journal of Advanced Nursing, 7, 2, 147-56.

Latimer, J. (1997) Giving patients a future: the constituting of classes in an acute medical unit, Sociology of Health \& Illness, 19, 2, 160-85.

Latimer, J. (1998) Organizing context: nurses' assessments of older people in an acute medical unit, Nursing Inquiry, 5, 1, 43-57.

Mackway-Jones, K., Marsden, J., Windle, J. and Manchester Triage Group (2014) Emergency Triage. 3rd edn. Chichester: Wiley.

Mannon, J.M. (1976) Defining and treating 'problem patients' in a hospital emergency room, Medical Care, 14, 12, 1004-13.

Mead, G.H. (1934) Mind, Self, and Society: From the Standpoint of a Social Behaviorist. Chicago: University of Chicago Press.

Norwegian Nurses Organisation (2011) Ethical Guidelines for Nurses. Available at https://www.nsf.no/ Content/785285/NSF-263428-v1-YER-hefte_pdf.pdf (Last accessed 1 April 2017).

Palmer, C.E. (1983) 'Trauma junkies' and street work occupational behavior of paramedics and emergency medical technicians, Journal of Contemporary Ethnography, 12, 2, 162-83.

Polletta, F., Chen, P.C.B., Gardner, B.G. and Motes, A. (2011) The sociology of storytelling, Annual Review of Sociology, 37, 109-30.

Ridgeway, C.L. (2014) Why status matters for inequality, American Sociological Review, 79, 1, 1-16.

Roth, J.A. (1971) Utilization of the hospital emergency department, Journal of Health and Social Behavior, 12, 4, 312-20.

Roth, J.A. (1972) Some contingencies of the moral evaluation and control of clientele: the case of the hospital emergency service, American Journal of Sociology, 77, 5, 839-56.

Roth, J.A. and Douglas, D.J. (1983) No Appointment Necessary: The Hospital Emergency Department in the Medical Services World. New York, NY: Irvington Publishers.

Schutz, A. (1967) Phenomenology of the Social World. Evanston: Northwestern University Press.

Sointu, E. (2017) 'Good' patient/'bad' patient: clinical learning and the entrenching of inequality, Sociology of Health \& Illness, 39, 1, 63-77.

Thwaites, T., Davis, L. and Mules, W. (2002) Introducing Cultural and Media Studies: A Semiotic Approach. Houndmills: Palgrave.

Tolich, M. (2004) Internal confidentiality: When confidentiality assurances fail relational informants, Qualitative Sociology, 27, 1, 101-6.

Vassy, C. (2001) Categorisation and micro-rationing: access to care in a French emergency department, Sociology of Health \& Illness, 23, 5, 615-32.

Vassy, C. (2014) Emergency departments. In Cockerham, W., Dingwall, R., and Quah, S. (eds.) The Wiley Blackwell Encyclopedia of Health, Illness, Behavior, and Society. Chichester: John Wiley \& Sons.

Veltkamp, G. and Brown, P. (2017) The everyday risk work of Dutch child-healthcare professionals: inferring 'safe' and 'good' parenting through trust, as mediated by a lens of gender and class, Sociology of Health \& Illness, 39, 8, 1297-313.

Wamsiedel, M. (2016) Lay values, organizational concerns, and the handling of 'social cases' in Romanian emergency Departments, Transylvanian Review, 25, Supplement 1, 61-76.

Zerubavel, E. (1997) Social Mindscapes: An Invitation to Cognitive Sociology. Cambridge: Harvard University Press. 



\section{Article 4}

Johannessen, L.E.F. (forthcoming). The commensuration of pain: How nurses transform subjective experience into objective numbers. Under review in Social Studies of Science. 



\title{
The commensuration of pain: How nurses transform subjective experience into objective numbers
}

\begin{abstract}
Commensuration - the transformation of different qualities into a common metric - has recently received increased scholarly attention. While most studies approach commensuration as a centralised, macroscale phenomenon, this article explores commensurative work at the micro-scale. Based on fieldwork in a Norwegian emergency medical service, the article analyses how nurses rated patients' pain intensity on a scale from zero to ten. After exploring why nurses disregarded patients' self-reported pain scores — in violation of guidelines and despite the belief that pain is a subjective phenomenon - the paper reconstructs the principles, methods and beliefs underlying nurses' 'objective' approach to pain scoring, which selectively transformed pain to the advantage of some patients and the disadvantage of others. In addition to demonstrating how a fundamental aspect of human experience is filtered through nurses' professional gaze, the article advances the study of microscale commensuration as a discretionary, selective and consequential phenomenon of great sociological interest.
\end{abstract}

Word count: 8338

Key words: Commensuration; discretion; ethnography; pain assessment; quantification; standardisation 


\section{Introduction}

Pain presents a unique problem in terms of measurement, and a unique cruelty in terms of suffering.

-Eula Biss, The Pain Scale

Why can't a dog simulate pain? Is he too honest? - Ludwig Wittgenstein, Philosophical Investigations In recent decades, social scientists have begun to pay more explicit attention to commensuration, the process of transforming qualitative differences into a common metric (Espeland and Stevens 1998, 2008). Commensuration is a ubiquitous and fundamental feature of modern societies, as evidenced by the proliferation of rankings, cost-benefit analyses and standardised tests across a range of institutional settings. While its ubiquity and apparent objectivity can make commensuration easy to overlook, Espeland and Stevens (2008: 406) have urged scholars not to take these processes for granted; instead, we should question the work and conventions that underpin the production of seemingly neutral numbers. This is particularly crucial because commensuration is a transformative process, emphasising certain aspects of the objects that it measures while downplaying others (Espeland and Stevens 1998: 314-8).

Whereas previous research has primarily studied centralised commensuration at the macroscale, this article extends the focus to microscale commensurative work. It does so by exploring a puzzling case of pain scoring, drawn from my fieldwork in a Norwegian emergency primary care clinic (EPCC). The EPCC in question was a walk-in clinic similar to emergency departments in other countries. Its frontline personnel were triage nurses, who assessed the urgency of patients' complaints. As part of their assessment, nurses were required to score patients' pain intensity using the Numeric Rating Scale (NRS), an 11-point scale ranging from zero ('no pain') to 10 ('the worst pain imaginable'). The EPCC's formal triage guidelines specified that nurses should score pain by combining their own assessment with the patient's self-reported pain score, respectively referred to by nurses as 'objective and 'subjective' NRS. However, nurses did not adhere to these guidelines; instead of combining the two ratings, they relied almost solely on the 'objective' NRS, asking patients to self-report their pain score only when the 'objective' NRS was considered ambiguous or inconclusive. Such deviations from guidelines are of course not uncommon (cf. Timmermans and Epstein 2010), but this particular practice seemed puzzling, as self-report is widely seen as 'the gold standard' for pain assessment (cf. Pierik et al. 2017). Indeed, one influential definition states that pain is "whatever the experiencing person says it is, existing whenever the experiencing 
person says it does" (McCaffery \& Beebe 1994: 15, cited in Woodrow 2002: 62).

Additionally, nurses themselves commonly insisted that pain is a subjective phenomenon. This raises two important questions: Why did nurses disregard patients 'subjective' pain score, and what did their 'objective' approach entail?

To address these questions, the present study employs an ethnographic approach that emphasises Verstehen -i.e. considering “actors' situated intentions, beliefs, and opportunities" (Turco and Zuckerman 2017: 1273) to locate their actions "in an intelligible and more inclusive context of meaning" (Weber 1978: 8). This approach serves to foreground the situated logic of nurses' commensuration of pain, which has largely been neglected in previous studies of pain assessments. Specifically, the article shows that nurses considered 'subjective' NRS to be antithetical to pain assessment, and how they instead relied on a range of 'objective' methods and principles they believed would provide more correct, consistent and efficient commensuration. While facilitating decision making in triage, this 'objective' approach also transformed the phenomenon of pain in significant ways, with systematic consequences concerning who and what was prioritised. Thus, in analysing nurses' commensuration of pain, the present article seeks both to advance the study of microscale commensuration and to demonstrate how a fundamental aspect of human experience is filtered through nurses' professional gaze.

In the following, I review existing studies of commensuration and pain; describe the study's data and methods, and then present and discuss the study's findings.

\section{Commensuration and pain}

Although implicit in much social scientific work (cf. Simmel 1978), the study of commensuration has been most explicitly formulated by Espeland and Stevens (1998, 2008). Commensuration is a form of quantification ${ }^{1}$ in which qualities are reduced to quantities and distinctions between objects become a question of magnitude (Espeland and Stevens 1998: 316). It is also a form of classification, sorting people or things into categories of 'more or less'. Forms of commensuration vary in their elaboration, ranging from complex indexes such as The Human Development Index to simple measures such as the NRS. Regardless of level of complexity, however, all forms of commensuration transform the objects that they

\footnotetext{
${ }^{1}$ Not all quantification entails commensuration; some is purely symbolic, as in the differentiation of soccer players based on their jersey number (Espeland and Stevens 2008: 407).
} 
measure; as such, commensuration can be understood as "a system for discarding information and organizing what remains into new forms" (Espeland and Stevens 1998: 317).

Studies of commensuration encompass a wide range of cases, including valuation in art markets (Velthuis 2003), law school rankings (Espeland and Sauder 2007) and university technology licensing boards (Owen-Smith 2005). Examples from healthcare include Whooley's (2016) study of the 'failed' attempt to grade mental disorders in the Diagnostic and Statistical Manual of Mental Disorders and Essén and Oborn's (2017) study of the 'performativity' of numbers in a Swedish rheumatology unit. To the best of my knowledge, however, no study to date has analysed pain assessment as a form of commensuration.

In general, social scientific studies have shown a preference for exploring patients' rather than professionals' perspectives on pain (cf. Frank 1997; Greenhalgh 2001; Kleinman 1988). While these studies have given important demonstrations of the "enormous chasm between embodied experience and professional evaluation" (Bendelow 2006: 59-60), they leave the professional perspective largely unexplored. Some notable exceptions include macro-oriented studies of how pain is conceptualised within the broader context of biomedical culture (Bendelow and Williams 1995; Morris 1993; Scarry 1985), and more micro-oriented studies of chronic pain clinics (Baszanger 1992; Buchbinder 2015; Crowley-Matoka and True 2012; Vrancken 1989). However, few researchers have explored the actual practice of assessing pain (Vuille et al. 2017 is a notable exception, to which I will return in the Discussion). Insofar as pain assessments have attracted academic attention, this is predominantly in studies that assess the quality of clinicians' assessments (cf. Duignan and Dunn 2008; Modanloo 2010; Pierik et al. 2017; Prkachin et al. 2007; Puntillo et al. 2003; Solomon 2001; Teanby 2003). Comparing clinicians' with patients' own pain scores, these studies show that clinicians systematically give lower pain scores than patients do, and that the discrepancy is greater for experienced clinicians. However, while this discrepancy is interesting, it tells us little about how and why clinicians assess pain the way they do.

In exploring how triage nurses commensurate pain in their everyday practice, the present article addresses four under-analysed aspects of commensuration, namely (1) marginally elaborated, (2) decentralised, (3) commensurative work (4) at a microscale. To elaborate (in reverse order): Focusing on the micro level, this article complements the more predominant macro-oriented studies, such as those analysing the broader cultural and institutional arrangements that make commensuration possible (cf. Fourcade 2011; Huault and RainelliWeiss 2011; Khaire 2014; Samiolo 2012) and historical studies tracing the increasing 
emphasis on quantification in modern societies (cf. Desrosières 2002; Hacking 1990; Porter 1996). Although less extensive, micro-studies facilitate exploration of commensuration as a situated practice performed by particular actors, while also linking their practice to meso- and macro-level concerns. Closely related, the article also focuses on commensurative work, thus complementing studies that focus more exclusively on the meanings and social consequences of commensuration (cf. Espeland and Sauder 2007; Sauder and Espeland 2009). The latter are of course important, but as they privilege how numbers work over the work of making numbers, they have less to say about the transformative aspects of commensurative work itself. Additionally, in focusing on decentralised commensuration (i.e. number production as dispersed between a large number of actors), the article complements studies of centralised commensurators such as governmental agencies and corporations (cf. Rottenburg et al. 2015). As decentralised number production is typically less standardised, questions of discretion and variation become more central to the analysis.

A small number of other studies have also analysed commensurative work as a decentralised, micro-level practice. For instance, Lamont (2009) has analysed how members of peer review panels work to render applications commensurate, and Lynch (2018) has studied how legal actors accomplish — and circumvent — the numbers-based logic of federal sentencing guidelines. In contrast, the present article examines commensuration under conditions of significant time pressure and uncertainty, where metrics are less elaborated than in more deliberative settings. Actors have to 'think fast' (Kahneman 2011) when scoring, and in so doing, they rely on a range of routines and heuristics to elaborate their guidelines (Lipsky 1980: 63-5). As well as exhibiting the same transformative effects as 'slower' commensuration, this 'faster' commensurative work depends largely on experiential, common-sense and unsanctioned knowledge. Scrutiny of fast and decentralised commensuration is therefore highly relevant, especially in professional settings, where workers typically have significant power over clients.

\section{Data and methods}

The article draws on data from a Norwegian EPCC. In general, EPCCs are heterogeneous institutions, ranging from single physicians on call in rural areas to large-scale urban organisations employing hundreds of workers. The largest EPCCs are open to all patients at all times, and in contrast to Norwegian emergency departments (EDs), they allow patients to walk in at their own discretion. Because they also serve patients across the entire spectrum of criticality, these large-scale EPCCs resemble EDs in most other Western countries (Vassy 
2014). The clinic under study was one such large-scale EPCC. It was located in the city centre, performed more than 50,000 consultations per year, employed more than 100 nurses and physicians and was open for 24 hours on every day of the week. The clinic was intended to serve patients with medical rather than surgical conditions.

Fieldwork at this EPCC was conducted between April and December 2015. The 47 fieldwork sessions had an average duration of approximately six hours. ${ }^{2}$ Of these, 20 sessions were spent observing nurses in triage and asking them about their assessments in close proximity to actual patients, which was crucial because of the ephemeral and largely unspoken nature of nurses' 'objective' pain scoring. In total, I observed 342 face-to-face assessments, performed by 2 male and 14 female nurses, most of whom were aged between 25 and 35 years. All of these nurses held a bachelor's degree in nursing (as is required for the protected title of 'nurse' in Norway); on average, they had worked in this EPCC for 3.5 years (range 1-7 years). I also attended two mandatory courses in triage nursing and conducted semi-structured interviews with seven nurses, two physicians and two managers, in which pain assessment was an important theme.

The interviews were transcribed verbatim. During fieldwork sessions, I scribbled keywords and near-verbatim quotes on a notepad or laptop for subsequent use in more elaborate field notes, yielding approximately 1,270 single-spaced pages. As all notes were written in Norwegian, I have translated the extracts included here, making minor grammatical and aesthetic adjustments.

The study was approved by Norwegian Social Scientific Data Services. Pseudonyms are used to secure informants' internal and external confidentiality, and no other identifying information is disclosed. I signed non-disclosure agreements with the participating EPCCs and secured workers' informed consent by distributing an information letter and delivering several short presentations on the project. When interacting with patients, each EPCC worker I shadowed would ask the patient whether it was acceptable that I witnessed their interaction. Analysis began immediately on entering the research setting. I learned about nurses' 'objective' approach to pain scoring quite early in the fieldwork and subsequently dedicated significant time and attention to understanding what that approach entailed and why they favoured it. For the purposes of this article, relevant field notes have been inductively

\footnotetext{
${ }^{2}$ For the purpose of analytical contrast, a further nine fieldwork sessions were conducted at two other emergency institutions.
} 
differentiated and iteratively reviewed to explore the logics of nurses' pain scoring. The results of this process are presented in the next section.

\section{Findings}

In considering how nurses commensurate pain in triage, I begin with a general overview of triage and pain assessments. After describing the nurses' objections against 'subjective' NRS, I go on to review their 'objective' approach, which they considered a more correct, consistent and efficient method of assessing pain.

\section{Triage and pain assessments}

Working at the clinic's frontline, the EPCC triage nurses sat in booths and called patients individually. Triage was often carried out under hectic conditions, as the waiting room was noisy, the queue to triage could be long, and there was always the risk that those waiting to be triaged might be critically ill. As nurses assessed anywhere between 40 and 70 patients during busy shifts, triage was considered tiring work. (Having witnessed approximately 60 unique assessments on my first day in the field, I can attest to this.) A triage assessment typically lasted 4-8 minutes, during which time the nurse would record a brief medical history, collect vital parameters and perform simple examinations before assigning an urgency level. While all of this information had to be documented for each assessment, their geographical separation from the rest of the clinic meant that there was little direct supervision of nurses' practices.

To regulate nurses' assessments, the clinic used the Manchester Triage System (MTS), which is currently the most widely used triage system in Europe. ${ }^{3}$ Designed as a paper-based manual, the system consists of 53 flow charts ordered by 'chief complaints', such as abdominal pain, allergy, ear problems and head injury. Nurses must assess patients using the most relevant of these charts, each of which lists 'discriminators' (i.e. symptoms and signs) related to the complaint in question. The system has five formal levels of priority; known as 'triage codes', these are referred to by colour: red (most urgent), orange, yellow, green and blue (least urgent). ${ }^{4}$

Pain, in the form of an NRS score, is a separate discriminator in 44 of the MTS' 53 flowcharts (it is not included in charts like 'asthma' and 'intoxication'). The 11 NRS scores

\footnotetext{
${ }^{3}$ Nurses did not always adhere to the requirements of the MTS, nor were they always expected to do so; see Johannessen (2017, 2018b).

${ }^{4}$ As it ranks patients in five-layered hierarchy of urgency, the MTS is itself a form of commensuration.
} 
are distributed across the bottom four triage codes; 0 corresponds to a 'blue' priority, $1-4$ is 'green', 5-7 is 'yellow', and 8-10 is an 'orange' priority. The latter two priorities have specific target wait times, set at sixty and ten minutes, respectively. The inclusion of pain as a separate criterion for priority setting reflects a broader shift in how pain is conceptualised in biomedical culture; it is now seen as harmful in itself rather than just as a symptom of something else (Morris 1993: 74). ${ }^{5}$ This is also symptomatic of how EMS organisations, in response to allegations of poor pain management, have sought to make pain assessments a required and standardised aspect of triage (Teanby 2003).

The MTS, then, requires nurses to express pain intensity in the form of a single NRS score; and as noted earlier, this score should comprise two sub-measures: the patient's self-report and the nurse's own clinical pain assessment (nurses referred to these as 'subjective' and 'objective' NRS, respectively - two terms that are notably absent from the MTS itself). Beyond this, the system offers few instructions for combining the two measures or for clinically assessing patients' pain. This is left largely to nurses' own discretion.

In these circumstances, nurses themselves had to 'fill in the blanks' of the system. They got some further instructions in the course they were required to attend prior to practising triage, where they were told repeatedly to privilege their own 'objective' score over the patient's self-report. In observing triage assessments, I found that nurses imposed an even more hierarchical relationship between the two measures; of the 342 assessments I observed, I noted only five instances in which nurses asked patients to self-report their score. This was no anomaly; nurses commonly claimed that they had stopped using the 'subjective' NRS unless they considered the 'objective' score ambiguous or inconclusive. The next section explores why.

\section{The problems with 'subjective' NRS}

In the clinic under study, the 'subjective' NRS was widely perceived as a flawed measure. Nurses' objections were multiple. First, many patients were said to unknowingly distort their score-in particular, they were thought to overreport their pain through anxiety or fear. Second, some patients were perceived as intentionally underreporting or exaggerating their score. While underreporting was attributed to a range of different motives-for example, wanting to appear brave or to avoid troubling EPCC workers-intentional exaggeration was

\footnotetext{
${ }^{5}$ Nurses were also required to assess more symptom-oriented aspects of patients' pain, such as its character, duration and location.
} 
seen primarily as an attempt to cheat the queue. Third, nurses also claimed that many patients lacked imagination when comparing their pain to the NRS end-point (defined as 'the worst pain imaginable'). Nurse Hanna described this with a mixture of humour and annoyance when she confided: "I had a patient who sat calmly in his chair and talking, saying 'NRS 10'—and then I thought, 'So, if I kick you in the nuts right now, you wouldn't feel more pain?!'”. In these nurses' view, then, the 'subjective' NRS ran counter to the aims of scoring pain consistently and correctly. These are important aims across healthcare settings and may account for why other workers (e.g. in post-operative units) have been found to disregard subjective scores (cf. Solomon 2001). However, nurses seemed to consider the 'subjective' NRS to be particularly antithetical to triage assessments, as pain scores are used here to rank patients in line to see a physician. Ranking requires pain scores to be spread across the whole scale - something that patients allegedly failed to do; and as Nurse Thomas put it, "There's no use having a triage system if everyone gets orange".

An additional problem was that asking for 'subjective' NRS could lead to time-consuming discussions. Consider the following account by Nurse Helga.

In the beginning, when we started using triage, we tried to ask every patient about it [NRS]. And then we saw that a lot of them were quick to say eight, nine, ten, leading to discussions like "But, you're walking okay and you're sitting calmly ...", and there's no use discussing NRS with the patients.

Such discussion was considered anathema to triage, as it wastes time and potentially puts sicker patients at risk (and, potentially, the nurse too; an internal annual report documented 173 reported incidences of threats and violence towards nurses in the clinic). As nurses considered themselves better pain raters, they preferred to refrain from asking patients about 'subjective' NRS.

Nurses' objections stand in remarkable contrast to the notion of self-report as the 'gold standard' of pain assessment; instead, nurses considered 'subjective' NRS unfit for the situation it is intended to standardise. In its place, they relied on an 'objective' approach to pain assessment, whose key principles are detailed in the following sections.

\section{'Objective’ assessments}

The advantages of an 'objective' approach may seem self-evident, given that the term suggests an unbiased, factual assessment. However, as firmly established in science studies (cf. Daston 1992; Porter 1996; Shapin and Schaffer 2011; Shapin 1995), what is designated 
'objective' can vary across time, place and actors. It seems useful, then, to unpack what this 'objective' approach entailed in the present case.

A first point of entry is nurses' reliance on so-called 'objective' signs. These were expressions of pain that are directly or indirectly observable, such as a particular form of body language (e.g. restlessness, facial contractions, gestures towards the painful area); reduced functional capacity (e.g. inability to walk upright, sit down, breathe properly, or eat and drink without feeling pain) and certain physiological changes (e.g. raised pulse, pallor or sweating).

As the term 'objective' suggests, these signs were granted significant validity. However, 'objectivity' was treated in continuous rather than binary terms, which meant that some signs were seen as purer expressions of pain than others. The most 'tainted' signs were patients' self-reported pain scores, closely followed by their verbal descriptions (the latter were granted some weight, as evidenced by how nurses regularly asked patients whether they were in 'discomfort' or 'pain'). Behavioural signs of the more familiar and easily manipulated kind were assigned somewhat greater validity, whereas the more esoteric and less governable behavioural signs (e.g. a particularly restless body language), as well as physiological signs, were considered purest.

Hierarchical notions of this kind are common features of human interaction; as Goffman (1959: 18) remarked, people regularly "use what are considered to be the ungovernable aspects of [a person's] expressive behaviour as a check upon the validity of what is conveyed by the governable aspects". On the other hand, it is worth reflecting on the principles underlying the nurses' hierarchy, especially because they so starkly contradict the idea that pain is a subjective phenomenon. To understand this ordering, we must first situate nurses' approach within a more general biomedical understanding of pain and the body. With the advent of 'scientific medicine' in the eighteenth and nineteenth centuries, clinicians increasingly sought "to bypass patient-narratives in their search for an 'objective' diagnosis" (Bourke 2014: 256; see also Jewson 1976). Subsequently, pain was conceptualised less in terms of an experiencing subject and more in terms of stimuli and response, shifting the focus to an internal 'pain system' that carries messages from pain receptors in the skin to a pain centre in the brain before being expressed mechanistically in observable signs (Bendelow and Williams 1995: 141). The 1960s saw a renewed emphasis on patients' subjectivity, with the introduction of the gate control theory of pain (Melzack and Wall 1965), in which psychological and cognitive processes were seen to influence how people perceive and respond to pain. In its wake, accounts placing exclusive emphasis on the mechanistic aspects 
of pain, without acknowledging the role of subjectivity, have lost traction in scientific circles. However, this does not preclude the privileging of an mechanistic understanding in clinical practice; as Bendelow and Williams argued (1995: 145), clinicians often seem to equate 'real pain' with "something that is acute with an easily observable physiological pathology".

It was primarily such a mechanistic conception of 'real' physical pain that underpinned nurses' understanding of 'objective' signs and their 'objective' approach more generally. This is not to say that nurses always and intentionally approached pain in mechanistic terms (i.e. as directly readable from patients' bodies and behaviour); rather, this was an assumption that they often privileged in their pain assessments. The reasons for this seem closely connected to the situational requirements of triage; reducing pain to an observable, physical phenomenon enables nurses to rank patients on a single dimension rather than having to weigh this against other, more subjective dimensions. Moreover, this reduction more easily meets the need to assess patients quickly; instead of engaging in potentially time-consuming dialogue with the patient, nurses can observe 'objective' signs while attending to other matters. It also allows nurses to assume a rough linear correlation between pain as experienced on the inside (due to pain stimuli) and pain as expressed on the outside (in the form of 'objective' signs), which, in turn, can readily be translated into a discrete score on the pain scale.

Treating pain mechanistically as a physical, observable phenomenon therefore simplified nurses' commensurative work; in their view, this allowed them to assign pain scores quickly and with greater precision and consistency than if they had simply relied on patients' selfreports. This provides a basic insight into nurses' objective' approach; for a deeper understanding, we must consider some additional techniques and principles.

\section{Error checking}

As suggested by their hierarchy of validity, nurses did not take patients' pain expressions at face value. On the contrary, they employed a range of techniques to correct for what they believed to be sources of error. Let us consider some salient examples.

First, nurses appraised whether 'objective' signs were significant in their absence. As pain was assumed to express itself in at least some observable signs, patients displaying no 'objective' signs were taken to be in little or no pain. The most referenced example was patients sitting calmly in their chair, claiming to have a pain score of ten. Similarly, nurses typically discounted patients who claimed to be in severe pain, only to answer 'no' when 
asked if they had taken painkillers. ${ }^{6}$ Illustrating the abovementioned hierarchy of validity, Nurse Madeleine also explained, "If [you claim] your stomach really hurts and your pulse is 70 , then I think, 'Okay, you're not in that much pain'; but with a pulse of 120, then I know something's not right". As these examples show, the absence of 'objective' signs was taken to suggest exaggeration, and nurses therefore had to adjust pain scores accordingly.

Second, nurses also appraised signs in light of the pain interval of the patient's condition. By 'pain interval' I mean the range of pain stimuli and, consequently, of pain scores associated with a particular condition. Some conditions (e.g. abdominal pain) were seen to have wide intervals, potentially ranging from top to bottom of the NRS. Other conditions had narrower intervals; for instance, ear pains and sore throats stereotypically entailed little pain while gallstones and kidney stones were believed to elicit intense pain. Using these notions of inherent or "normal' ${ }^{77}$ pain, nurses could check whether patients' verbal and behavioural expressions of pain were misaligned with their condition. Accordingly, patients expressing pain outside their interval (e.g. by sobbing dramatically over ear pains or a sore throat) were suspected of distorting their 'real' level of pain.

Third, nurses also looked for behavioural slip-ups in patients' impression management (Goffman 1959). Typical examples included patients who came limping into triage only to walk flawlessly when leaving the assessment, or patients who came laughing into the clinic only to appear deadly serious in the triage booth. Nurses also made more elaborate inferences about how patients 'really' felt about their pain. For instance, Nurse Julie explained, "If you come in, put your purse on the floor and your coffee on the table, claiming, 'I'm in real pain', then I'm thinking that you're probably in pain but not so much that you couldn't manage to buy coffee first'. In other words, such 'slip-ups' were taken to suggest a discrepancy between claimed and 'real' pain, which nurses had to take into account.

Finally, nurses also tried to compensate for the fact that certain patients may have a 'different' way of expressing their pain. Nurse Madeleine argued this point with reference to certain 'cultures'.

Certain cultures, for instance, they often express themselves in a different way in response to illness. It's a lot of shouting and hollering and body movements and stuff you often-[when I smile to encourage

\footnotetext{
${ }^{6}$ The emphasis on 'objective' signs also relates to how these suggest 'doctorable' problems (Heritage and Robinson 2006), i.e. problems that require a physician's attention. For instance, questions about painkillers were employed not only to reveal 'exaggeration' but also to identify patients whose problems could be resolved simply by taking non-prescription painkillers - something that nurses could offer them in triage.

${ }^{7}$ Notions of 'normal pain' resemble the 'normal crimes' documented in Sudnow (1965).
} 
her to continue, she seemingly interprets my smile as disbelief.] But it's true! [I express understanding.] And then you develop this attitude of "Okay, but they're not that ill, right?" That's the way they behave, they tend to exaggerate.

Madeleine's account illustrates the widespread belief that patients from certain 'cultures' behave in a particularly expressive way, and how this expressive behaviour might be interpreted as 'exaggeration'. She did not specify the 'cultural' group in question, but others attributed these particular characteristics to Somali women. Note, however, that nurses did not assert that there are cultural differences in how patients experience or endure pain-only that certain groups express pain more strongly than others. ${ }^{8}$ Attending to this latter issue is actually encouraged in the MTS handbook, which states that nurses' pain assessments must take account of how cultural groups "differ in how they respond to, or express, their pain" (Mackway-Jones et al. 2014: 32). ${ }^{9}$ This is supposed to increase the validity of nurses' pain scoring; put simply, if members of one group express pain more strongly than those of other groups, their information should be weighted to arrive at a more correct assessment. Accordingly, the most remarkable aspect of Madeleine's account is not necessarily that she holds generalised beliefs about particular patient groups; for present purposes, the more noteworthy point is that these beliefs are seen to serve an important role in calibrating nurses' commensuration. More examples could be cited, but the underlying point remains the same; nurses perceived several sources of error in their data and sought to correct these in order to more precisely quantify pain.

\section{Benchmarks}

A final principle for ensuring consistent commensuration was the use of fixed reference points for the pain scale. While some of these have already been hinted at (e.g. sore throat, gallstones), this section foregrounds nurses' use of fixed end-points for 'the worst pain imaginable'.

Although not universally embraced in the EPCC, fixed end-points were a commonly claimed feature of nurses' assessments. In general, these were used as benchmarks for assessing the intensity of a patient's pain expression - as illustrated in the following backstage account by Nurse Natalie, concerning patients who make exaggerated claims about back pain.

\footnotetext{
${ }^{8}$ Differences in expression are well documented (cf. the classical contributions of Zborowski 1952; Zola 1966). For beliefs about differences in endurance, see Bourke (2014).

${ }^{9}$ The MTS does not, however, conceptualise cultural differences in terms such as 'exaggeration'.
} 
If you've given birth, right, then you'd say that just as you're pushing the head out, then you're at ten. [She jokingly simulates the midwife's voice] "Are you at ten now?" And then you have them [patients with back pain], standing like this [she grasps her lower back and sways her body dramatically back and forth, imitating the patient], "You know, I have such terrible pains in my back, it has to be a nine", and I'm like, "No, if it had been a nine, then you'd be like this" [she bends over, standing as if her back was completely stuck].

Natalie's account illustrates, first, how she equates an NRS score of 10 with the climactic moments of giving birth, and, second, how this reference point (together with the absence of certain 'objective' signs) is taken as grounds for discounting patients' exaggerated assertions. Nurses' reliance on benchmarks such as birth pains implies that they assess pain from an inter-patient perspective, in which patients' complaints are judged according to nurses' standards, rather than adopting an intra-patient perspective that relates pain intensity to the patient's own reference points. Opting for the latter would have been particularly challenging considering that nurses assessed unknown patients, whose pain thresholds could not be established reliably within a brief triage assessment. In its place, the use of nurse-determined benchmarks seemed a fitting proxy, ensuring, in nurses' view, that pain was scored according to a stable and 'objective' standard.

This is not to say, however, that all nurses shared exactly the same standards; on the contrary, some seemed to set the bar higher than Nurse Natalie. For instance, Nurse Hanna, who referred to herself as a 'strict' pain assessor, equated birth pains with an NRS score of 8 , reserving the 10 for 'torture'. ${ }^{10}$ This suggests less than perfect reliability between nurses' ratings. Consequently, with all else being equal, the same patients would receive different pain scores depending on whether a nurse like Natalie or Hanna assessed them.

That said, daily EPCC socialisation ensured that pain was assessed according to a similar if not identical metric. Working in a large clinic meant interacting regularly with colleagues, and this served to align nurses' beliefs about pain and the standards for its assessment. Of particular importance was nurses regular interactions with the clinic's coordinating nurse and physician, who monitored patient flow and followed up on patients post-triage. Among other things, coordinators sanction nurses when their pain ratings (and assessments more generally) seem too out of tune with agreed-upon standards. Although relatively infrequent (I observed

\footnotetext{
${ }^{10}$ Interestingly, Hanna and other 'strict' nurses typically expressed their 'strictness' with some pride. This can be partly understood in light of the widespread belief that the EPCC was 'abused' by patients with 'trivial' complaints (explored more thoroughly in Johannessen (2018a), for which reason 'strictness' served as an important form of adult education. This 'strictness' can also be understood to have a seasoned, distinguishing quality that sets the 'strict' apart from those who indiscriminately empathise with the most trivial of pains.
} 
only one case), these sanctions could have a significant preventive effect, in the sense that nurses sought to mimic the standards of their colleagues in order to avoid being reproached. In combination with other everyday exchanges - such as passing remarks about difficult, interesting or frustrating cases or more elaborate stories about exaggeration and the signs thereof - such collegial interactions contributed to aligning nurses' pain assessments, creating an intersubjective agreement that was seemingly perceived as common sense and factual (see Shapin 2012: 176).

This brings us again to the problems associated with 'subjective' NRS. While nurses could work to align each other's assessments, they had only limited influence on patients' standards. Educating one's clientele during brief, one-off encounters was considered a waste of time and effort and could even cause patients to feel alienated or distrusted. Thus, while the sociology of standardisation (Timmermans and Epstein 2010) offers rich illustrations of the challenges in standardising professionals' behaviour, 'subjective' NRS highlights the additional and arguably more challenging issue of standardising patients' conduct.

Finally, it is worth noting that some patients were considered better than others at rating their pain. For instance, it was suggested that the elderly are more appropriately imaginative than others; as Nurse Natalie jokingly explained, “Older people have more experience, so they're probably better at assessing, like, 'It wasn't exactly like when I was shot during the war, but it kinda feels like it"'. Similarly, patients who work in healthcare were simply said to 'get' the NRS; as Nurse Miriam proclaimed, "It's great with healthcare workers who know the NRS-I just ask and then write what they say". Thus, as long as patients were seen to follow nurses' standards, their self-report could be used for commensuration.

\section{Discussion}

This article has explored how triage nurses commensurate pain on a scale from zero to ten. Formally, nurses were required to combine patients' self-reported 'subjective' scores with their own 'objective' assessments; in practice, however, they relied almost solely on the latter. This 'objective' approach included a reliance on certain 'objective' signs, checking for various 'errors' and using nurse-determined benchmarks for 'the worst pain imaginable'. Nurses believed that this approach enabled more correct, consistent and efficient pain scoring, in marked contrast to 'subjective' NRS, which they considered a dubious and inconsistent standard. 
This 'objective' approach is not exclusive to the nurses under study. For instance, in their study of a Swiss ED, Vuille and colleagues (2017) found that nurses preferred 'objective' data to patients' self-report; had different methods for assessing patient credibility; relied on what has been described here as an inter-patient perspective; and used fixed end-points in their assessments. Based on the above analysis, we can hypothesise that reliance on an 'objective', nurse-determined approach is intimately linked to having to make (1) quick and (2) unidimensional assessments of (3) previously unknown patients while (4) being part of, or accountable to, a biomedical culture that places a premium on 'objective' evidence. In short, these are situations where an 'objective' approach is likely to be considered the most reliable and efficient proxy for rating patients' pain. However, further research is needed before drawing any more robust conclusion about the relationship between pain assessment and context.

In attending closely to nurses' pain ratings, the present study illustrates the transformative nature of micro-level commensurate work. In disregarding 'subjective' NRS, nurses rendered pain a professional concern, in which proper assessment relied on their professional gaze and standards. As suggested in the analysis, one key element was the reification of pain as a 'thing' to be determined by reference to the absence or presence of 'objective' signs. This means that the nurses treated pain in much the same way as other disease entities (Chiong 2001) in biomedicine - that is, as "distinct, objective entities that are common to afflicted patients" (Chiong 2001: 90). Needless to say, this stands in marked contrast to those treating pain as a subjective phenomenon, where patients are seen as the experts.

Approaching pain 'objectively' has systematic consequences for the prioritisation of patients. For one, nurses' reliance on 'objective' signs means that patients who are less expressive than the mean (e.g. 'stoics') risk being assigned lower pain scores. Conversely, some groupsespecially the young and certain minority cultures - were believed to express pain in a 'different' and exaggerated way. While such assumptions play an important calibrating role in nurses' assessments, they are not unproblematic; specifically, when individuals are judged according to perceived group characteristics, they may be suspected of exaggerating even when evidence of exaggeration is absent. This is a general problem with stereotypical reasoning, often referenced by critics of related practices such as statistical discrimination (Pager and Karafin 2009) and racial profiling (Harris 1999).

That said, the present analysis also demonstrates how commensurative work is shaped by organisational constraints, and how these impose significant limitations on nurses' pain 
assessments. Every day, triage nurses face loads of complete strangers, whose subjective experience must be assessed as quickly as possible while nurses simultaneously attend to other aspects of the assessment. For that reason, their scoring necessarily depends on routines and heuristics, entailing various blind spots (cf. Lipsky 1980). While it is important to illuminate these blind spots and to thoroughly debate them, it is equally important to realise that nurses' working conditions place significant limits on what pain can be in this context (see also Graham and Herndl 2013). Such organisational constraints are of crucial importance, both for understanding and improving nurses' assessments and for analysis of commensurative work more generally.

Analysing decentralised commensuration also foregrounds issues of standardisation and variability. While the NRS successfully standardises the form of nurses' pain assessments (as a number on a scale from zero to ten), we have seen that nurses deviated from the logic of pain scoring as specified in the MTS. In short, they considered 'subjective' NRS unfit for the situation it was intended to standardise. In part, this follows from the use of the NRS for ranking as well as rating in the clinic under study. In other words, pain scores were used both to express patients' individual experiences of pain and to order those experiences in a hierarchy—a task for which nurses deemed their 'objective' approach more appropriate. Consequently, there was a gap between the general standard of 'subjective' NRS and the specific goals it was meant to achieve-a common problem that is well documented in the sociology of standardisation (Timmermans and Berg 2003; Timmermans and Epstein 2010).

However, while nurses may arguably be justified in questioning the validity of 'subjective' NRS, there is reason to question whether their 'objective' approach yields adequate ranking of patients. In short, nurses' ratings of pain relative to their own benchmarks (e.g. 'birth pains', 'torture') may run counter to the point of singling out pain intensity as a separate criterion for priority setting. That point is to prioritise those who are experiencing pain-and, qua experience, pain is arguably determined by patients' rather than nurses' reference points (cf. Bourke 2014). Privileging the latter can be problematic, especially as nurses are known to become 'stricter' assessors of pain as they gain experience (cf. Prkachin et al. 2007), and that this is likely to make them too far removed from the standards that shape patients' experience. This suggests a strong need for developers and implementers of guidelines to find ways of incorporating patients' voice in the pain assessment, while simultaneously allowing nurses to rank patients consistently. 
In closing, I would encourage social scientists to focus more explicitly on micro-scale commensurative work. Although there are many implicit studies of such work (cf. Latour and Woolgar 1986), the elusive quality of both commensuration and micro-practice can conceal the broader significance and family resemblance of these practices. To combat this, we must reflect more explicitly and critically — and with greater amazement — on the work of creating seemingly neutral numbers. While the present article contributes to this endeavour, more studies are needed to probe: How do commensurators commensurate? How is their work shaped by the circumstances under which it takes place? What criteria, methods, principles and broader epistemological concerns underpins their work, and how do these transform the commensurated objects? To whom are the commensurators accountable? And what are the broader implications of their work?

\section{References}

Baszanger, I. (1992) Deciphering chronic pain, Sociology of Health \& Illness. 14, 2, 181-215. Bendelow, G.A. (2006) Pain, suffering and risk, Health, Risk \& Society. 8, 1, 59-70.

Bendelow, G.A. and Williams, S.J. (1995) Transcending the dualisms: towards a sociology of pain, Sociology of Health \& Illness. 17, 2, 139-65.

Bourke, J. (2014) The story of pain: From prayer to painkillers. New York, NY: OUP Oxford.

Buchbinder, M. (2015) All in Your Head: Making Sense of Pediatric Pain. Oakland, California: University of California Press.

Chiong, W. (2001) Diagnosing and defining disease, JAMA. 285, 1, 89-90.

Crowley-Matoka, M. and True, G. (2012) No one wants to be the candy man: Ambivalent Medicalization and Clinician Subjectivity in Pain Management, Cultural Anthropology. 27, 4, 689-712.

Daston, L. (1992) Objectivity and the Escape from Perspective, Social Studies of Science. 22, 4, 597-618.

Desrosières, A. (2002) The Politics of Large Numbers: A History of Statistical Reasoning. Cambridge, Mass. u.a.: Harvard University Press.

Duignan, M. and Dunn, V. (2008) Congruence of pain assessment between nurses and emergency department patients: A replication, International Emergency Nursing. 16, $1,23-8$.

Espeland, W. and Stevens, M. (1998) Commensuration as a social process, Annual Review of Sociology. 24, 1, 313-43. 
Espeland, W.N. and Sauder, M. (2007) Rankings and Reactivity: How Public Measures Recreate Social Worlds, American Journal of Sociology. 113, 1, 1-40.

Espeland, W.N. and Stevens, M.L. (2008) A sociology of quantification, European Journal of Sociology / Archives Européennes de Sociologie. 49, 3, 401-36.

Essén, A. and Oborn, E. (2017) The performativity of numbers in illness management: The case of Swedish Rheumatology, Social Science \& Medicine. 184, Supplement C, 134 43.

Fourcade, M. (2011) Cents and Sensibility: Economic Valuation and the Nature of 'Nature', American Journal of Sociology. 116, 6, 1721-77.

Frank, A.W. (1997) The wounded storyteller: Body, illness, and ethics. Chicago: University of Chicago Press.

Goffman, E. (1959) The presentation of self in everyday life. Garden City, N.Y.: Doubleday.

Graham, S.S. and Herndl, C. (2013) Multiple Ontologies in Pain Management: Toward a Postplural Rhetoric of Science, Technical Communication Quarterly. 22, 2, 103-25.

Greenhalgh, S. (2001) Under the Medical Gaze: Facts and Fictions of Chronic Pain. Berkeley: University of California Press.

Hacking, I. (1990) The Taming of Chance. 1 edition. Cambridge England ; New York: Cambridge University Press.

Harris, D.A. (1999) Driving while Black: Racial profiling on our nation's highways. American Civil Liberties Union Washington, DC.

Heritage, J. and Robinson, J.D. (2006) Accounting for the visit: Giving reasons for seeking medical care. In Heritage, J. and Maynard, D.W. (eds.) Communication in medical care: Interaction between primary care physicians and patients. pp. 48-85.

Huault, I. and Rainelli-Weiss, H. (2011) A Market for Weather Risk? Conflicting Metrics, Attempts at Compromise, and Limits to Commensuration, Organization Studies. 32 , $10,1395-419$.

Jewson, N.D. (1976) The Disappearance of the Sick-Man from Medical Cosmology, 17701870, Sociology. 10, 2, 225-44.

Johannessen, L.E.F. (2017) Beyond guidelines: Discretionary practice in face-to-face triage nursing, Sociology of Health \& Illness. 39, 7, 1180-94.

Johannessen, L.E.F. (2018a) Narratives and gatekeeping: Making sense of triage nurses' practice, Sociology of Health \& Illness. 
Johannessen, L.E.F. (2018b) Workplace assimilation and professional jurisdiction: How nurses learn to blur the nursing-medical boundary, Social Science \& Medicine. 201,51-8.

Kahneman, D. (2011) Thinking, fast and slow. New York: Farrar, Straus and Giroux.

Khaire, M. (2014) Fashioning an Industry: Socio-cognitive Processes in the Construction of Worth of a New Industry, Organization Studies. 35, 1, 41-74.

Kleinman, A. (1988) The illness narratives: suffering, healing, and the human condition. New York: Basic Books.

Lamont, M. (2009) How professors think: inside the curious world of academic judgment. Cambridge, Mass: Harvard University Press.

Latour, B. and Woolgar, S. (1986) Laboratory life: the construction of scientific facts. New Jersey: Princeton University Press.

Lipsky, M. (1980) Street-level bureaucracy: dilemmas of the individual in public services. New York: Russell Sage Foundation.

Lynch, M. (2018) The narrative of the number: quantification in criminal court, Law \& Social Inquiry. $\mathrm{n} / \mathrm{a}-\mathrm{n} / \mathrm{a}$.

Mackway-Jones, K., Marsden, J., Windle, J. and Manchester Triage Group (2014) Emergency triage. 3rd ed. Chichester: Wiley.

Melzack, R. and Wall, P. (1965) Pain mechanisms: a new theory, Science. 150, 3699, 971-9.

Modanloo, M. (2010) Comparison of pain assessment by patients and triage nurses, Iranian Journal of Critical Care Nursing. 3,23-8.

Morris, D.B. (1993) The Culture of Pain. Berkeley: University of California Press.

Owen-Smith, J. (2005) Dockets, Deals, and Sagas: Commensuration and the Rationalization of Experience in University Licensing, Social Studies of Science. 35, 1, 69-97.

Pager, D. and Karafin, D. (2009) Bayesian Bigot? Statistical Discrimination, Stereotypes, and Employer Decision Making, The ANNALS of the American Academy of Political and Social Science. 621, 1, 70-93.

Pierik, J.G.J., IJzerman, M.J., Gaakeer, M.I., Vollenbroek-Hutten, M.M.R., et al. (2017) Painful Discrimination in the Emergency Department: Risk Factors for Underassessment of Patients' Pain by Nurses, Journal of Emergency Nursing.

Porter, T.M. (1996) Trust in Numbers. Reprint edition. Princeton, N.J: Princeton University Press. 
Prkachin, K.M., Solomon, P.E. and Ross, J. (2007) Underestimation of pain by health-care providers: towards a model of the process of inferring pain in others, The Canadian Journal of Nursing Research. 39, 2, 88-106.

Puntillo, K., Neighbor, M., O’Neil, N. and Nixon, R. (2003) Accuracy of emergency nurses in assessment of patients' pain, Pain Management Nursing. 4, 4, 171-5.

Rottenburg, R., Merry, S.E., Park, S.-J., and Mugler, J. (eds.) (2015) The World of Indicators: The Making of Governmental Knowledge through Quantification. Cambridge, United Kingdom: Cambridge University Press.

Samiolo, R. (2012) Commensuration and styles of reasoning: Venice, cost-benefit, and the defence of place, Accounting, Organizations and Society. 37, 6, 382-402.

Sauder, M. and Espeland, W.N. (2009) The Discipline of Rankings: Tight Coupling and Organizational Change, American Sociological Review. 74, 1, 63-82.

Scarry, E. (1985) OCLC: ocn687780316. The body in pain: the making and unmaking of the world. New York: Oxford University Press.

Shapin, S. (1995) A Social History of Truth: Civility and Science in Seventeenth-Century England. 1 edition. Chicago: University Of Chicago Press.

Shapin, S. (2012) The sciences of subjectivity, Social Studies of Science. 42, 2, 170-84.

Shapin, S. and Schaffer, S. (2011) Leviathan and the Air-Pump: Hobbes, Boyle, and the Experimental Life. With a New introduction by the authors edition. Princeton, N.J: Princeton University Press.

Simmel, G. (1978) The philosophy of money. London: Routledge \& Kegan Paul.

Solomon, P. (2001) Congruence between health professionals' and patients' pain ratings: a review of the literature, Scandinavian Journal of Caring Sciences. 15, 2, 174-80.

Sudnow, D. (1965) Normal Crimes: Sociological Features of the Penal Code in a Public Defender Office, Social Problems. 12, 3, 255-76.

Teanby, S. (2003) A literature review into pain assessment at triage in accident and emergency departments, Accident and Emergency Nursing. 11, 1, 12-7.

Timmermans, S. and Berg, M. (2003) The gold standard: the challenge of evidence-based medicine and standardization in health care. Philadelphia, Pa: Temple University Press.

Timmermans, S. and Epstein, S. (2010) A world of standards but not a standard world: Toward a sociology of standards and standardization, Annual Review of Sociology. 36, $1,69-89$. 
Turco, C.J. and Zuckerman, E.W. (2017) Verstehen for sociology: comment on Watts, American Journal of Sociology. 122, 4, 1272-91.

Vassy, C. (2014) Emergency departments. In Cockerham, W., Dingwall, R., and Quah, S. (eds.) The Wiley Blackwell Encyclopedia of Health, Illness, Behavior, and Society. Chichester: Wiley-Blackwell.

Velthuis, O. (2003) Symbolic meanings of prices: Constructing the value of contemporary art in Amsterdam and New York galleries, Theory and Society. 32, 2, 181-215.

Vrancken, M.A.E. (1989) Schools of thought on pain, Social Science \& Medicine . 29, 3, 43544.

Vuille, M., Foerster, M., Foucault, E. and Hugli, O. (2017) Pain assessment by emergency nurses at triage in the emergency department: A qualitative study, Journal of Clinical Nursing.

Weber, M. (1978) Economy and society: an outline of interpretive sociology. Berkeley, Calif.: University of California Press.

Whooley, O. (2016) Measuring mental disorders: The failed commensuration project of DSM-5, Social Science \& Medicine. 166, Supplement C, 33-40.

Woodrow, P. (2002) Google-Books-ID: qoDeGVwiE6EC. Intensive Care Nursing: A Framework for Practice. Routledge.

Zborowski, M. (1952) Cultural Components in Responses to Pain, Journal of Social Issues. 8, $4,16-30$.

Zola, I.K. (1966) Culture and Symptoms--An Analysis of Patient's Presenting Complaints, American Sociological Review. 31, 5, 615-30. 